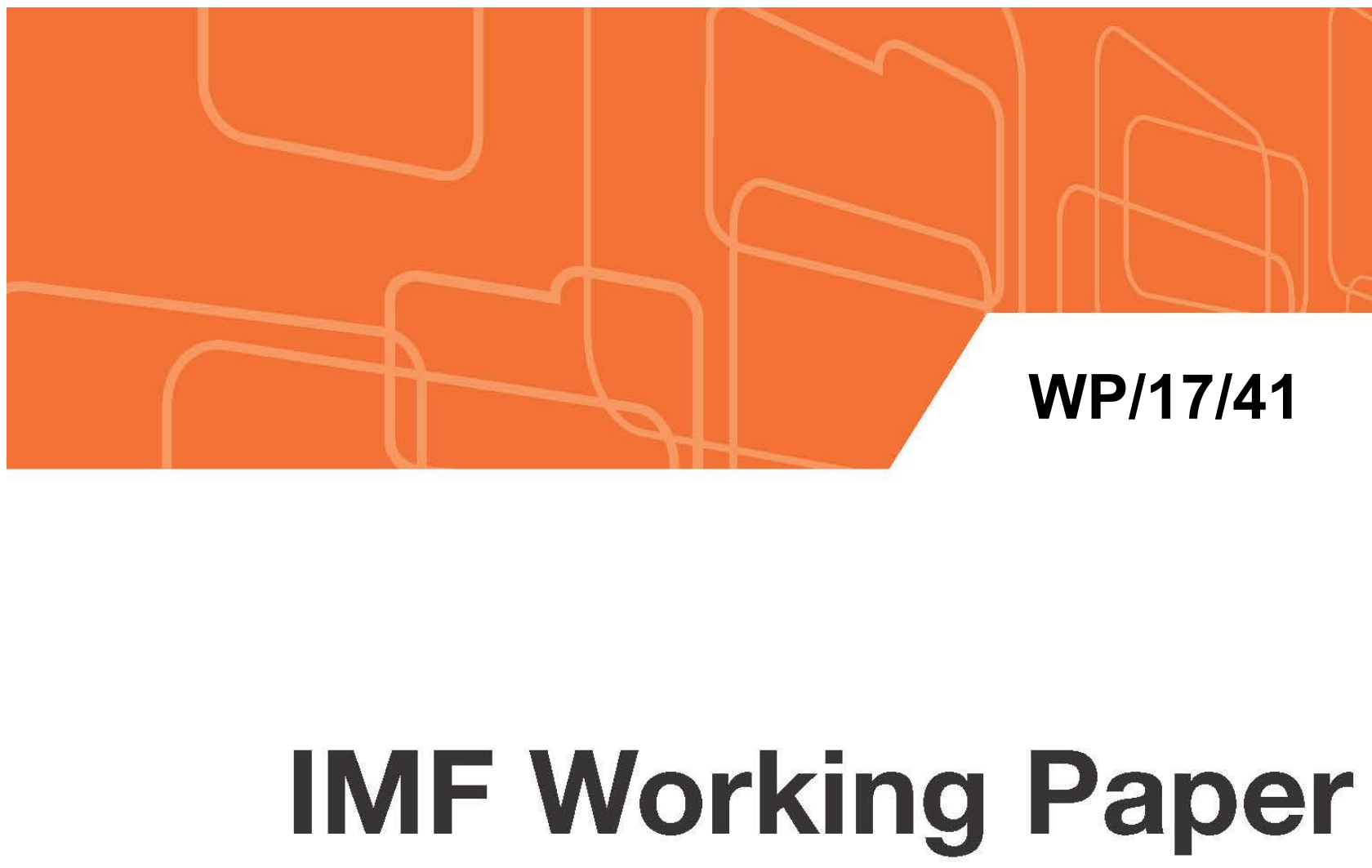

\title{
The Volatility of Capital Flows in Emerging Markets: Measures and Determinants
}

by Maria Sole Pagliari and Swarnali Ahmed Hannan

IMF Working Papers describe research in progress by the author(s) and are published to elicit comments and to encourage debate. The views expressed in IMF Working Papers are those of the author(s) and do not necessarily represent the views of the IMF, its Executive Board, or IMF management. 


\title{
IMF Working Paper
}

Strategy, Policy and Review Department

\section{The Volatility of Capital Flows in Emerging Markets: Measures and Determinants Prepared by Maria Sole Pagliari and Swarnali Ahmed Hannan}

Authorized for distribution by Martin Kaufman

February 2017

IMF Working Papers describe research in progress by the author(s) and are published to elicit comments and to encourage debate. The views expressed in IMF Working Papers are those of the author(s) and do not necessarily represent the views of the IMF, its Executive Board, or IMF management.

\begin{abstract}
Capital flow volatility is a concern for macroeconomic and financial stability. Nonetheless, literature is scarce in this topic. Our paper sheds light on this issue in two dimensions. First, using quarterly data for 65 countries over the period 1970Q1-2016Q1, we construct three measures of volatility, for total capital flows and key instruments. Second, we perform panel regressions to understand the determinants of volatility. The measures show that the volatility of all instruments is prone to bouts, rising sharply during global shocks like the taper tantrum episode. Capital flow volatility thus remains a challenge for policy makers. The regression results suggest that push factors can be more important than pull factors in explaining volatility, illustrating that the characteristics of volatility can be different from those of the flows levels.
\end{abstract}

JEL Classification Numbers: C13, C33, C58, F32, F36, F44.

Keywords: Volatility Estimation, International Flows, Financial Integration Author's E-Mail Address: mpagliari@economics.rutgers.edu, sahmed@imf.org 


\section{Contents}

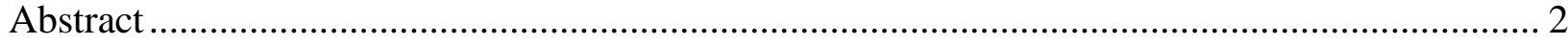

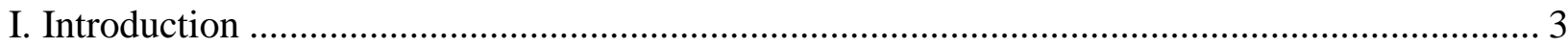

II. Evolution Of Capital Flows........................................................................................ 5

A. Heterogeneity across groups and flows: AEs vs EMDEs, gross vs net............................... 5

B. Heterogeneity across instruments: FDI, portfolio and Other flows ...................................... 8

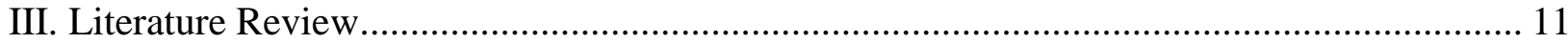

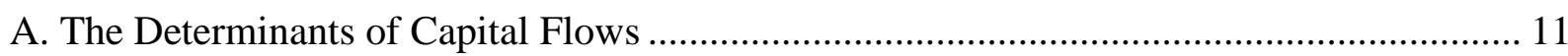

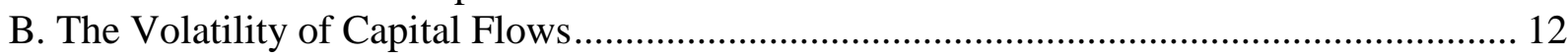

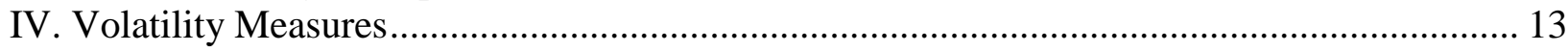

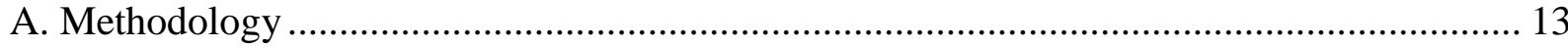

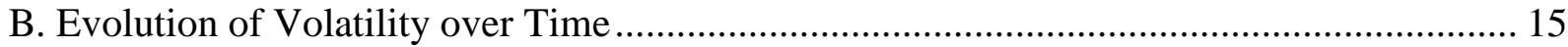

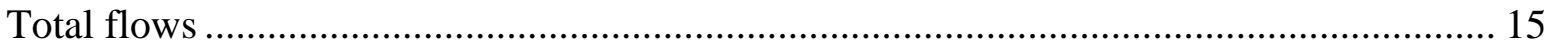

Individual components.................................................................................................... 19

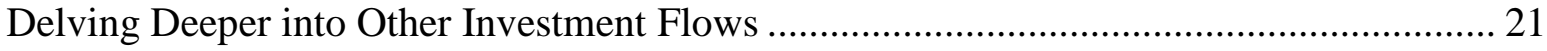

C. Volatility Measures for Individual countries ………….................................................. 24

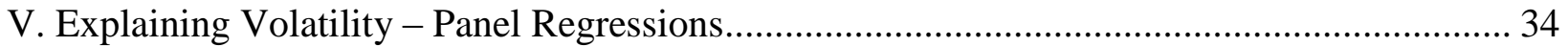

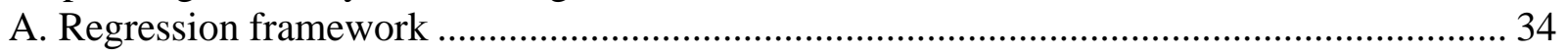

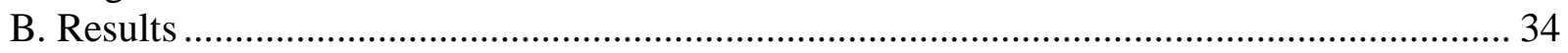

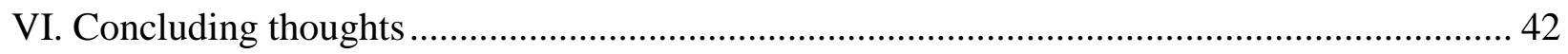

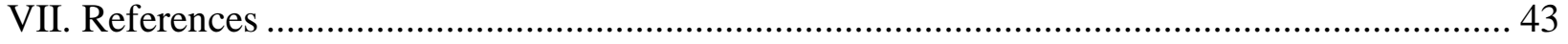

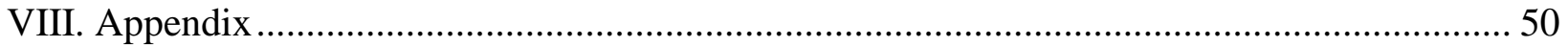

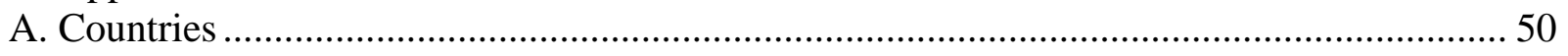

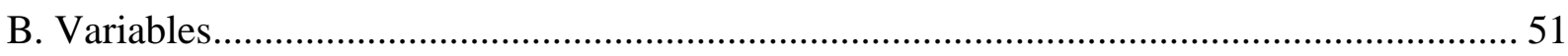

C. Geweke's Separated Partial Means Test ……………….................................................. 52

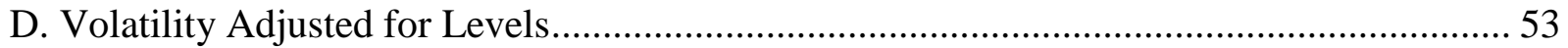

E. Volatility of Capital Flows excluding China ..................................................................... 55 


\section{INTRODUCTION ${ }^{1}$}

Capital flow volatility is a major source of concern for macroeconomic and financial stability in emerging market and developing economies (EMDEs). Over the last three decades, the emerging economies have liberalized their capital accounts and have become more integrated in international financial markets. However, as the Global Financial Crisis (GFC) has shown, reaping the benefits of capital account liberalization while containing the associated risks remains a key challenge for many countries for several reasons.

First, EMDEs tend to receive capital flows that, even in net terms, are large relative to their domestic economies and overall absorptive capacity in terms of the size and depth of their financial systems.

Second, EMDEs are more vulnerable to shocks, partly because their economies are smaller and less diversified, and because they have less domestic economic and political stability. In addition, shocks of any kind - positive or negative, domestic or external - are exacerbated and propagated more easily in EMDEs because of structural and institutional characteristics. In particular, large capital inflows, mostly intermediated through the banking system, tend to amplify the domestic financial and real business cycles to a greater extent than in advanced economies (AEs).

Finally, the GFC has prompted new concerns that flows to EMDEs are overly sensitive to some global (push) factors that are beyond the influence of domestic policies.

Given all this, financial integration poses serious challenges to economic and financial sector stability in EMDEs. ${ }^{2}$ To the extent that there exists a positive link between the stability of capital flows and economic growth (see Easterly, Islam, and Stiglitz 2001 and Ramey and Ramey 1995), maintaining a steady stream of capital flows is a policy priority in most EMDEs. Despite being a focus of policymakers, relatively few studies focus primarily on the issue of volatility. Moreover, capital flow volatility is usually quantified in policy and academic discussions using a crude measure of standard deviation of flows over a specified period. Given the importance of this issue, a better understanding of volatility in capital flows is warranted. This paper aims at providing a deeper understanding of volatility of capital flows by contributing to the existing literature along three important dimensions:

1) Measurements: The first step of this study consists of deriving measures that can usefully describe volatility. Our paper builds upon Broto et al. (2011) to provide updated capital flow volatility measures using three methodologies: rolling window standard deviation, $\operatorname{GARCH}(1,1)$ conditional variance and ARIMA $(1,1,0)$ estimates.

\footnotetext{
${ }^{1}$ We would like to thank Michael Bordo, Roberto Chang, Varapat Chensavasdijai, Martin Kaufman, Robin Koepke, John Landon-Lane, Sarah Sanya, and seminar participants at the IMF for their helpful suggestions and comments. This paper was prepared while Maria Sole Pagliari was a summer intern at the IMF. All remaining errors are ours.

${ }^{2}$ For instance, Broner and Ventura (2016) point out that financial globalization has sometimes led to capital flows that are volatile and procyclical.
} 
2) Determinants: In order to pursue policies to increase resilience and help manage capital flow volatility, it is important to understand the drivers of capital flow volatility. We perform panel regressions to understand what are the key variables driving volatility, by disentangling between, on the one hand, global or push factors and, on the other hand, domestic or pull factors.

3) Components: We analyze the evolution of volatility across a wide array of instruments. In particular, the high level of granularity of our dataset allows us to achieve a greater precision in the study of particular categories of flows.

Using quarterly data over the period 1970Q1-2016Q1, we use three measures of volatility to document its evolution over time. Our measures show that net capital flows to EMDEs tend to be more volatile than those of AEs, as gross outflows tend to dampen the impact of gross inflows in the latter group but not in the former. Our computed measures for gross inflows in EMDEs suggest that portfolio and other investments are respectively around two and four times more volatile than FDI. In addition, amongst portfolio flows, portfolio debt is more volatile than portfolio equity. As to other investment flows, private flows are much more volatile than the official sector ones. Within private flows, bank flows usually tend to be more volatile than non-bank flows, but there are periods where this does not hold.

For policymakers, it is not only the level of volatility but also the changes in volatility that matter. Therefore, we use our estimates to document the changes of volatility since 2000. Our computed measures suggest that, after a spike during the GFC, capital flow volatility in EMDEs is now back to pre-crisis levels. However, volatility has sharply risen in response to some after-crisis global shocks, particularly during the taper tantrum episode. Moreover, after accounting for the global slowdown in capital flows witnessed since 2012, EMDEs capital flow volatility has either increased or remained the same as before the crisis. There exists, however, a degree of heterogeneity in the results, depending on the type of flows targeted. Indeed, while foreign direct investments (FDIs) display a more clear-cut and stable volatility pattern over time, the same does not hold for other instruments, like portfolio or other flows. In particular, debt-generating instruments, notably portfolio debt and bank flows, were the main drivers of the large swings in volatility observed soon before and in the aftermath of the GFC.

One of the major contributions of our paper is that we produce capital flow volatility estimates, both for total flows and different instruments, for 65 individual countries. ${ }^{3}$ The individual country estimates suggest that there can be significant variation amongst countries, both in terms of the evolution over time and the relative magnitude across instruments, underscoring the importance of monitoring volatility of individual countries. These estimates can thus be useful tools in future studies dealing with cross-country comparisons.

We, then, use the volatility estimates at the country level to run panel regressions with the aim of understanding the determinants of volatility. Our regression analysis shows that push factors like the US monetary policy stance, US economic performance, and global risk aversion do influence the volatility of capital flows in EMDEs to an extent which, in certain cases, is greater than the effect of domestic and structural variables. These findings are interesting against the backdrop of

337 EMDEs and 28 AEs. See Appendix A for a list of countries. 
recent studies (e.g., IMF 2016) that show how the recent capital flow slowdown can be predominantly attributed to the broader emerging markets economic growth slowdown. Our results suggest that the determinants of capital flow volatility can be quite different from the determinants of capital flow levels.

The remainder of this paper is structured as follows: Section 2 provides some stylized facts concerning the evolution of capital flows to EMDEs and discusses the different types of data included in the dataset; Section 3 reviews the existing literature; Section 4 contains an overview of the methodological approaches adopted and analyzes the evolution of volatility of capital flows over time, across instruments and countries; Section 5 deals with the identification of the main drivers of volatility via panel regressions; Section 6 concludes.

\section{Evolution Of Capital Flows}

\section{A. Heterogeneity across groups and flows: AEs vs EMDEs, gross vs net.}

International capital gross inflows have experienced a remarkable rise from the mid-1990s to the first half of 2000s, both in EMDEs and AEs (Figure 1). Following the GFC in 2008, inflows dropped sharply in 2008 for both groups and regained their upward momentum in 2009, only to fall again in late 2011 as the peripheral Euro Area sovereign debt crisis intensified. Within this broader trend, there exist key differences across income groups. While net flows in AEs are influenced by both gross inflows and gross outflows, their patterns for EMDEs is mainly determined by gross inflows (Figure 1). This is because capital flows to EMDEs have been generally driven by foreign investments into domestic assets, while the amount of domestic investments abroad have played a smaller role. ${ }^{4}$ Given this background, when it comes to evaluating the volatility of capital flows, it is crucial to make a clear distinction not only across groups, but also between gross and net flows.

\footnotetext{
${ }^{4}$ In the last decade, however, EMDEs have started to increasingly invest abroad as well (see Obstfeld (2012)).
} 
AEs

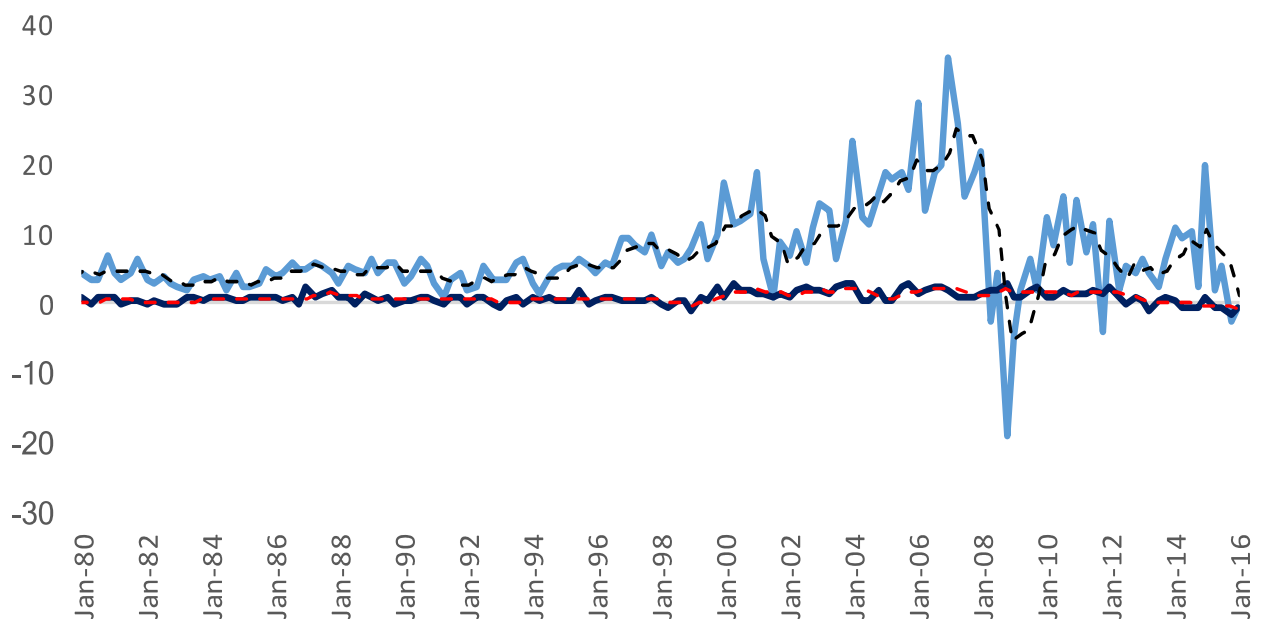

EMDES

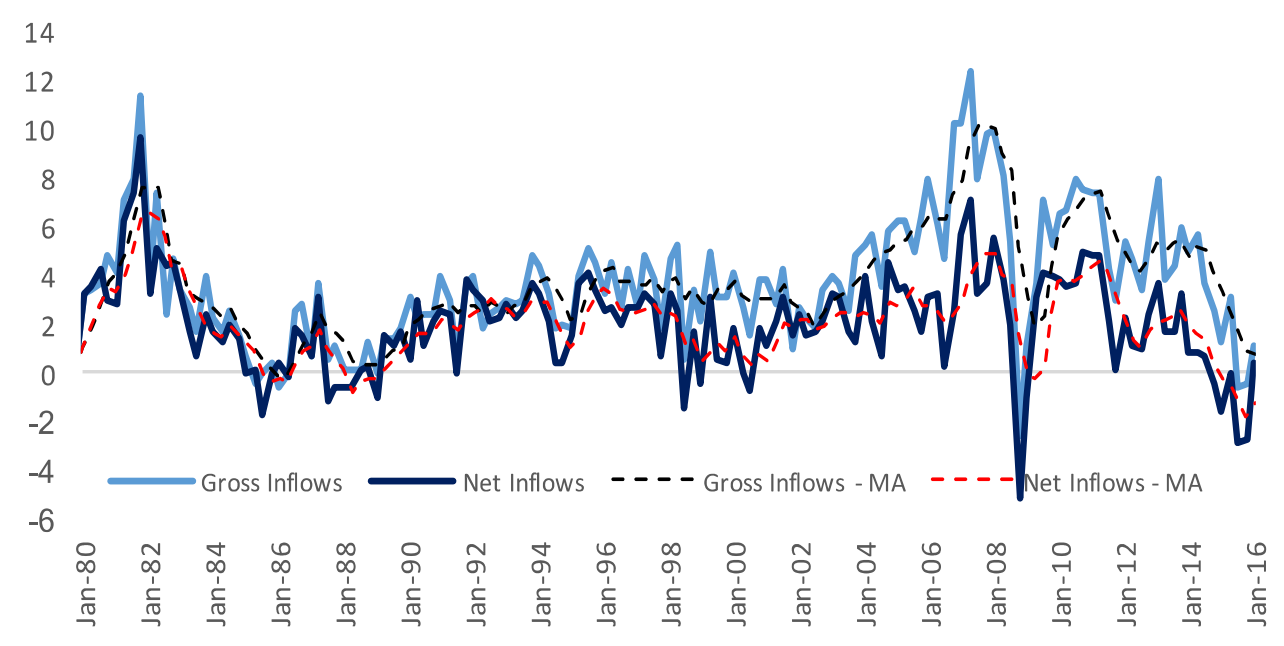

Figure 1: Cross border capital flows in AEs and EMDEs. Notes: flows are expressed as \% share of group GDP. Dashed lines are quarterly moving averages. Data are quarterly over the period 1980Q1:2016Q1. Source: IMF, International Financial Statistics. 
Table 1 reports some basic volatility measures of gross and net flows for both groups, computed over the period 1990Q1:2016Q1. The measures of volatility considered are two: the standard deviation of capital flows as a share of GDP and the coefficient of variation, that is the ratio between the standard deviation and the absolute value of the mean of the flows. Standard deviation is a measure suitable for making comparisons across groups whose average levels of flows are similar. When the means are widely different, however, the higher the mean the higher could be the dispersion of observations around it. In order to address this issue, the coefficient of variation is often a preferred measure to make comparisons across groups. ${ }^{5}$ The coefficient of variation could be problematic when the mean is close to zero, since the coefficient of variation will approach infinity and will be highly sensitive to small changes in the mean.

\begin{tabular}{|c|c|c|c|c|c|c|c|c|c|}
\hline & \multicolumn{3}{|c|}{ Average } & \multicolumn{3}{|c|}{ Standard deviation } & \multicolumn{3}{|c|}{ Coefficient of variation } \\
\hline & (1) & $(2)$ & (3) & (1) & $(2)$ & (3) & (1) & $(2)$ & (3) \\
\hline \multicolumn{10}{|l|}{$A E s$} \\
\hline 1990-1999 & 3.75 & 0.38 & 3.37 & 1.86 & 0.30 & 1.84 & 0.50 & 0.79 & 0.55 \\
\hline $2000-2007$ & 14.49 & 1.52 & 13.03 & 5.15 & 0.42 & 5.25 & 0.36 & 0.27 & 0.40 \\
\hline $2008-2015$ & 5.77 & 0.77 & 5.12 & 4.32 & 4.33 & 4.34 & 0.75 & 5.62 & 0.85 \\
\hline$\Delta 2000 / 07-1990 / 99$ & 10.75 & 1.14 & 9.67 & 3.29 & 0.11 & 3.41 & -0.14 & -0.52 & -0.14 \\
\hline$\Delta 2008 / 15-2000 / 07$ & -8.72 & -0.75 & -7.92 & -0.83 & 3.91 & -0.91 & 0.39 & 5.35 & 0.44 \\
\hline$\Delta 2008 / 15-1990 / 99$ & 2.02 & 0.39 & 1.75 & 2.46 & 4.02 & 2.50 & 0.25 & 4.82 & 0.30 \\
\hline \multicolumn{10}{|l|}{ 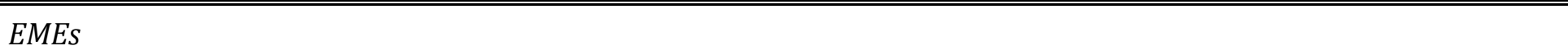 } \\
\hline 1990-1999 & 2.21 & 1.62 & 0.76 & 1.79 & 1.56 & 0.57 & 0.81 & 0.96 & 0.74 \\
\hline $2000-2007$ & 4.94 & 2.40 & 2.55 & 2.40 & 1.10 & 1.61 & 0.48 & 0.46 & 0.63 \\
\hline $2008-2015$ & 4.81 & 1.85 & 2.92 & 1.78 & 1.78 & 1.77 & 0.37 & 0.96 & 0.60 \\
\hline$\Delta 2000 / 07-1990 / 99$ & 2.73 & 0.77 & 1.79 & 0.60 & -0.46 & 1.04 & -0.33 & -0.50 & -0.11 \\
\hline$\Delta 2008 / 15-2000 / 07$ & -0.13 & -0.54 & 0.38 & -0.62 & 0.68 & 0.16 & -0.11 & 0.50 & -0.03 \\
\hline$\Delta 2008 / 15-1990 / 99$ & 2.60 & 0.23 & 2.16 & -0.01 & 0.22 & 1.20 & -0.44 & 0.00 & -0.14 \\
\hline
\end{tabular}

Table 1: Statistics for quarterly moving averages. Notes: average and standard deviation are expressed as \%

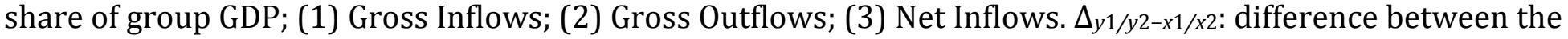
averages computed over periods $x_{1} / x_{2}$ and $y_{1} / y_{2}$.

In AEs, capital flow volatility, as indicated by the coefficient of variation, has increased over the period 1990-2016, by $0.25,4.82$ and 0.3 for gross inflows, gross outflows and net inflows respectively. In all cases, there has been a slight decrease in volatility up to the GFC, while it has increased during and after it (see Table 1). In EMDEs, on the other hand, the volatility of gross inflows and net inflows have fallen by 0.44 and 0.14 respectively over the same period.

\footnotetext{
${ }^{5}$ See Bluedorn, Duttagupta, Guajardo, and Topalova (2013). Another common practice is to linearly detrend the series to account for observed increases in the level over time. As a robustness check, we computed the estimates with linearly detrended data and we obtained very similar results.
} 


\section{B. Heterogeneity across instruments: FDI, portfolio and Other flows}

Besides the heterogeneities related to income groups and to the comparison between gross and net flows, another powerful source of heterogeneity stems from the composition of the aggregate flows. The overall dynamics of capital flows depend upon the dynamics of the specific components and, by analyzing the composition of the financial account, one can infer interesting information about the behaviour of international investors in different scenarios as well as have a better understanding of a country's financial stability.

The three instruments that are usually closely monitored are ${ }^{6}$ :

1. Foreign Direct Investments (FDI), "a category of cross-border investments associated with a resident in one economy having control or a significant degree of influence on the management of an enterprise that is resident in another economy";

1. Portfolio flows, "defined as cross-border transactions and positions involving debt or equity securities, other than those included in direct investment or reserve assets";

2. Other flows, "a residual category that includes positions and transactions other than those included in direct investment, portfolio investment, financial derivatives and employee stock options, and reserve assets", classified in government-related flows and private flows (bank and non-bank flows).

Figure 2 shows the evolution of gross and net inflows for EMDEs, broken down by instruments. While FDI represent the majority of capital inflows for EMDEs, the surge and the subsequent collapse in inflows during the GFC was mainly driven by other flows, which include bank flows. Even the post crisis pick-up in capital flows was led by debt-creating (bank and portfolio debt) instruments, with some reversals between 2015 and 2016. Therefore, one would expect different results when estimating volatility for different categories, with portfolio and other flows being characterized by a higher volatility.

\footnotetext{
${ }^{6}$ Definitions are taken from the sixth edition of the Balance of Payments and International Investment Position Manual (BPM6).
} 


\section{Gross Inflows}
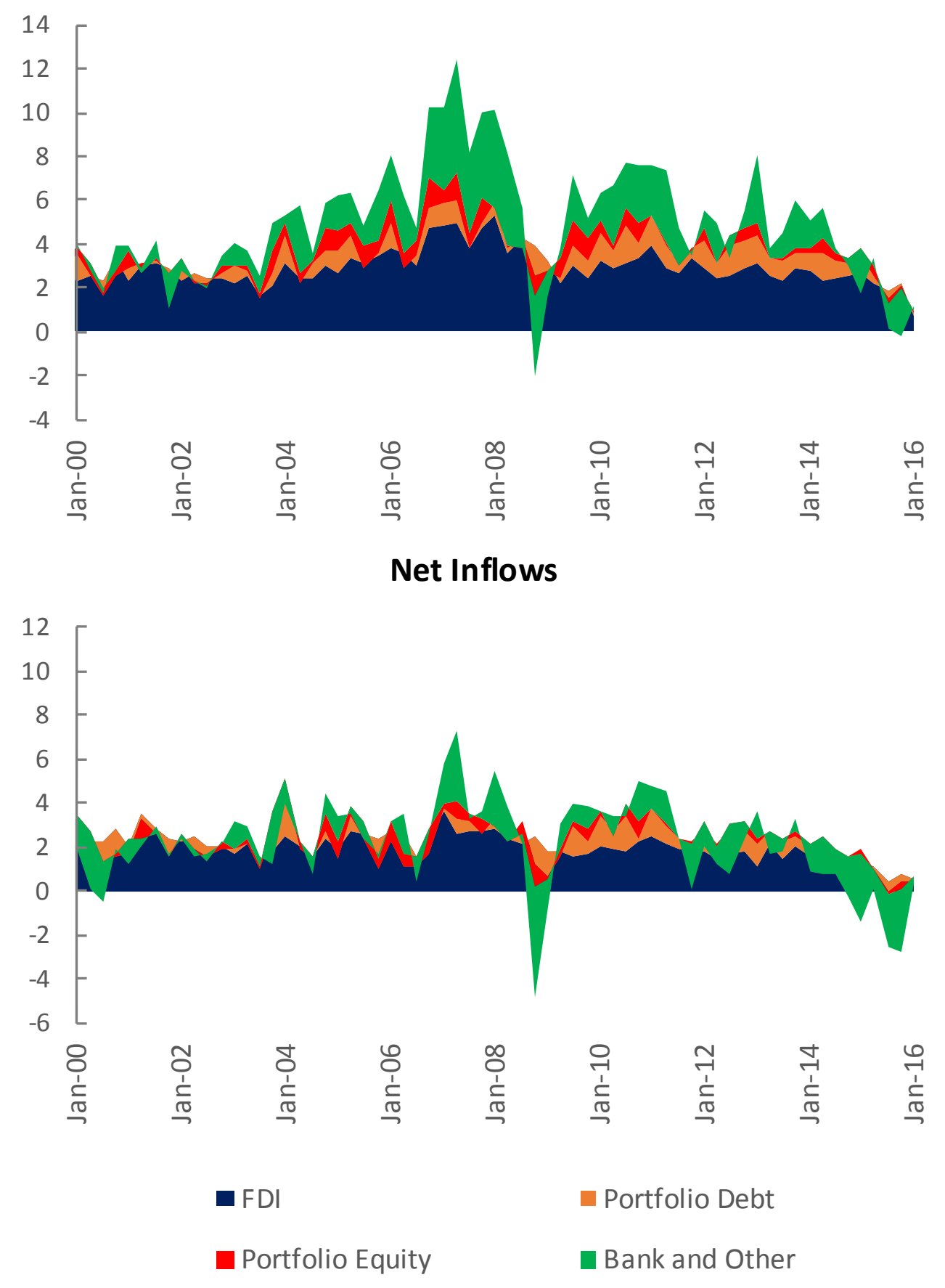

Figure 2: Quarterly moving average of Gross and Net Capital Inflows in EMDEs by instrument. Notes: flows are expressed as \% share of group GDP. Source: IMF, International Financial Statistics. 
Another aspect of particular relevance concerns the correlation across instruments and whether it has changed over time. In this regard, Figure 3 shows how the correlation coefficients across different types have evolved over time for EMDEs. The correlations across instruments are significantly different from 0 in certain periods. The most interesting case is provided by the correlation between FDI and portfolio flows, whose sign has switched from negative to positive and vice versa several times in the period covered. By comparing this picture with Figure 2, it is evident that episodes of surges coincide with a positive correlation between FDI and portfolio flows, while the same correlation turns negative soon after a stop. By contrast, this does not seem to be the case when it comes to co movements of both FDI and portfolio with other investments. The key message, however, is that there exists a degree of heterogeneity across instruments.
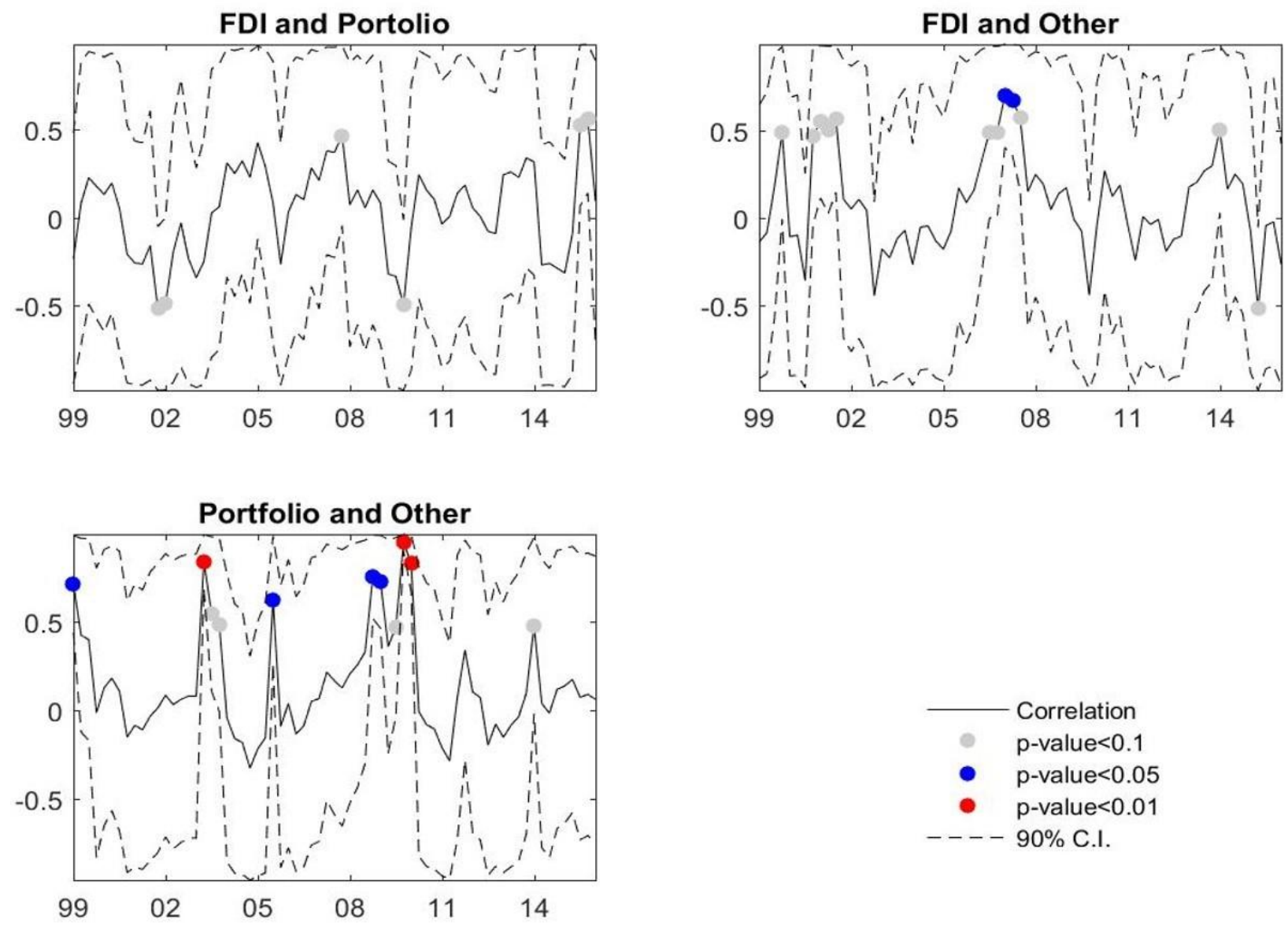

Figure 3: Evolution of the correlation coefficient across different types of Gross Inflows. Notes: the grey, blue and red dots indicate estimates significant at 10\%, 5\% and $1 \%$ respectively. Source: IMF, International Financial Statistics, authors' computations. 


\section{Literature REVIEW}

There exists a vast literature aimed at, on the one hand, identifying the main drivers of the evolution of international capital flows, and, on the other hand, measuring the potential gains from financial integration. $^{7}$

\section{A. The Determinants of Capital Flows}

Most of the literature classifies the main determinants of capital flow developments in countryspecific (pull) and global (push) factors (Koepke 2015). Among the latter, the most commonly identified are indicators of global risk appetite and US monetary policy. Reinhart et al. (1993) and Reinhart et al. (1996), for instance, argue that capital inflows to Latina America in the 1990s were influenced by conditions originated outside the region, a fact that increased the macroeconomic vulnerability of the economies in that region.

More recent literature explores whether push or pull factors determine capital flows. Fratzscher (2012), by means of a factor model, shows how push factors were overall the main drivers of capital flows during the crisis, while pull factors have been dominant in accounting for the dynamics of global capital flows in 2009 and 2010, in particular for EMDEs. In their analysis of episodes of "surges", "stops" (sharp increases and decreases, respectively, of gross inflows), "flight" and "retrenchment" (sharp increases and decreases, respectively, of gross outflows), Forbes and Warnock (2012) find that global risk is significantly associated with extreme capital flow episodes. Moreover, contagion, whether through trade, banking, or geography, is also associated with stop and retrenchment episodes, whereas domestic macroeconomic characteristics are generally less important. Agrippino and Rey (2014) find that one global factor explains an important part of the variance of a large cross section of returns of risky assets around the world. They interpret this global factor as reflecting the time-varying degree of market wide risk aversion and aggregate volatility, represented by the VIX, the Chicago Board Options Exchange Volatility Index. On top of that, they show that US monetary policy is a driver of this global factor in risky asset prices, the term spread and measures of the risk premium. Passari and Rey (2015) present evidence on the existence of a global financial cycle in gross cross-border flows, asset prices and leverage and identify the VIX as a suitable proxy for such cycle. This implies that there exist significant spillovers from the US monetary policy on capital flows to the EMDEs.

Other findings are provided by Ahmed and Zlate (2014), who highlight how growth and interest rate differentials between EMDEs and AEs and global risk appetite are statistically and economically important determinants of net private capital inflows to EMDEs. They also show that there is a positive effect of unconventional US monetary policy on EMDEs inflows, especially portfolio inflows, and that there have been significant changes in the behaviour of net inflows from the pre-crisis to the post-crisis period, partly explained by the greater sensitivity of such flows to interest rate differentials. Similarly, Ghosh et al. (2014b) find that global factors like US interest

\footnotetext{
${ }^{7}$ Notably, literature has attempted to measure gains from financial integration mainly in two ways: by testing for growth effects and better risk-sharing following financial account opening using either panel data or event studies and by calibrating standard international macroeconomic models and computing gains when going from autarky to financially integrated markets. See Jeanne et al. (2012) for a survey of the related empirical literature. See Kose et al. (2009) for an example of theoretical contribution.
} 
rates and VIX play a crucial role in determining capital surges to EMDEs. However, the occurrence and magnitude of a surge towards a particular EMDE also largely depend on domestic factors such as its external financing need, capital account openness, and exchange rate regime. Nonetheless, surges driven by exceptional behaviour of liability flows are relatively more sensitive to global factors and contagion.

Siemer et al. (2015) study the relationship between stock market volatility as a proxy for uncertainty and capital inflows using panel regressions and a portfolio choice model. They decompose each country's market return volatility into two components: systemic volatility, measured by uncertainty betas, and country-specific volatility. While it is true that capital inflows generally respond to changes in both components, however in countries with higher uncertainty betas capital inflows tend to be more sensitive to risk.

\section{B. The Volatility of Capital Flows}

The existing empirical literature dealing with the volatility of capital flows can be classified into two strands. ${ }^{8}$ On the one hand, some papers focus on analyzing the difference in volatility between the capital flows to emerging and advanced economies. For instance, Rigobon and Broner (2005) show that the higher volatility in EMDEs is primarily due to these economies' propensity to build up imbalances, which generates more persistent shocks and a higher likelihood of international contagion. Similarly, Alfaro et al. (2007) emphasize the importance of domestic factors, such as institutional quality and the soundness of macroeconomic policies, in explaining these volatility differences. Discrepancies between EMDEs and AEs can also be characterized by type of investment. For instance, the gap between the volatility of FDI and portfolio flows is found to be smaller in AEs (Goldstein and Razin 2006), whereas in EMDEs the share of FDI in total capital inflows is higher (Albuquerque 2003), as is the volatility of their portfolio flows (Tesar and Werner 1995).

Other contributions use panel data models to analyze the impact of financial integration on volatility. In this regard, Neumann et al. (2009) show that financial integration tends to increase the volatility of FDI in emerging economies, while reducing that of other debt flows in mature economies. In addition, Bekaert and Harvey (1997), Lagoarde-Segot (2009) and Umutlu et al. (2010), by focusing on prices rather than quantities, conclude that financial liberalization reduces the volatility of stock market returns in emerging economies. ${ }^{9}$ In a more recent study, Broto et al. (2011) analyze the determinants of the volatility of various types of net capital inflows to EMDEs, by using annual data over the period 1980-2006. Their main finding is that, since 2000, global factors have become increasingly significant relative to country-specific drivers. However, they also identify some domestic macroeconomic and financial factors that appear to reduce the volatility of certain instruments without increasing that of the others.

\footnotetext{
${ }^{8}$ Previous theoretical contributions include Bacchetta and Van Wincoop (1998), Aghion et al. (2004) and Martin and Rey (2006).

${ }^{9}$ See Chuang et al. (2009) and Jinjarak et al. (2011) for an analysis of the relationship between stock returns and volumes.
} 
Alberola et al. (2016) investigate the role of international reserves as a stabilizer of international capital flows, in particular during periods of financial distress. They show that international reserves facilitate financial disinvestment overseas by residents. This partially offsets the drop in foreign capital inflows observed in such periods. Moreover, larger stocks of international reserves are linked to higher gross inflows and lower gross outflows.

In a more recent paper, Broner and Ventura (2016) investigate the effects of financial globalization in EMDEs. By emphasizing the role of imperfect enforcement of domestic debts and the interactions between domestic and foreign debts, they show that financial globalization can produce three different outcomes: i) domestic capital flight and ambiguous effects on net capital flows, investment and growth; ii) capital inflows and higher investment and growth; iii) volatile capital flows and unstable financial markets. These effects ultimately depend on the level of development, productivity, domestic savings and the quality of institutions. In this paper we empirically investigate some of these aspects by expanding the work of Broto et al. (2011) to include the GFC period.

\section{Volatility Measures}

The first way to expand the existing literature is to build a dataset with broader coverage, in terms of both the time period considered and the instruments included. The empirical papers previously cited use annual data that go until 2010 and do not cover all the different categories included in the balance of payments. Our paper uses quarterly data, spanning from 1970Q1 to 2016Q1, and encompasses a wider set of capital flow instruments. ${ }^{10}$ These features allow us to carry on a more in-depth analysis of how volatility has evolved both over time, across countries and across instruments. In addition, while current literature has focused on the capital flow slowdown witnessed since 2012 (IMF 2016), our updated data sheds light on how capital flow volatility has evolved since then.

\section{A. Methodology}

In order to produce reliable estimates of capital flow volatility, we consider three approaches, building on Engle et al. (2005) and Broto et al. (2011):

\section{Standard deviations over a rolling window $(R W)$}

This consists of the standard deviation of capital flows computed over a rolling window as follows:

$$
\sigma_{i t}=\left(\frac{1}{n} \sum_{k=t-(n-1)}^{t}\left(\text { flow }_{i k}-\mu\right)^{2}\right)^{1 / 2}
$$

where $\mu=\frac{1}{n} \sum_{k=t-(n-1)}^{t}$ flow $_{i k}$ and flow $_{i k}$ denotes capital flows in country $i$ in period $k$. In these computations, $\mathrm{n}=4$ quarters.

\footnotetext{
${ }^{10}$ Refer to Appendix B for a list of the variables with time coverage and sources.
} 
As mentioned in Broto et al. (2011), there are some caveats associated with this measure:

a) there is a loss of data at the beginning of the sample, whose entity depends on the window length (n);

b) $\sigma_{i t}$ is strongly persistent and this might entail problems of endogeneity and serial correlation;

c) the same weights are assigned to $f l o w_{i(t-1)}$ and $f l o w_{i t-(n-1)}$, which overly smooths volatility. As a result, volatility might be underestimated when a shock takes place and overestimated thereafter, compared to other measures.

\section{Estimated standard deviations produced by a $G A R C H(1,1)$ model}

The second alternative measure makes use of estimated conditional volatilities of a $\operatorname{GARCH}(1,1)$ model. The process is defined as follows:

$$
\begin{gathered}
y_{i t}=\varepsilon_{i t} \sigma_{i t} \\
\sigma_{i t}^{2}=\alpha_{0}+\alpha_{1} \mathrm{y}_{i(t-1)}^{2}+\alpha_{2} \sigma_{i(t-1)}^{2},
\end{gathered}
$$

where $y_{i t} \equiv \Delta$ flow $i t, \varepsilon_{i t}$ is a Gaussian white noise process and $\sigma_{i t}^{2}$ is the corresponding conditional variance.

This measure, however, has its own drawbacks. Notably:

a) data scarcity might lead to convergence errors;

b) Maximum-Likelihood estimates for small samples contain biases;

c) stationarity and positivity of estimates require that $\widehat{\alpha_{1}}+\widehat{\alpha_{2}}<1, \widehat{\alpha_{0}}>0, \widehat{\alpha_{1}}>$ 0 and $\widehat{\alpha_{2}}>0$. If these conditions are violated for some country $i$, then the model fails to produce valid estimates for that country;

d) in some cases, the residuals do not present $\mathrm{ARCH}$ effects and that makes the GARCH model not suitable.

\section{Estimated standard deviations produced by an ARIMA(1,1,0) model}

The third measure is given by the standard deviation of the residuals obtained after fitting an ARIMA $(1,1,0)$ to the data. ${ }^{11}$ Notably, we first estimate the residuals from the following $\mathrm{AR}(1)$ process:

$$
\Delta \text { flow }_{i t}=c+\beta \Delta \text { flow }_{i(t-1)}+v_{i t}
$$

Then, a test is performed to detect the presence of any ARCH effects in the residuals. If the null hypothesis of heteroscedasticity is rejected:

$$
\sigma_{i t}^{2}=\frac{1}{4} \sum_{j=t-(\mathrm{n}-3)}^{t+(\mathrm{n}-2)}\left(v_{i j}\right)^{2}
$$

otherwise conditional volatility is estimated by fitting a $\operatorname{GARCH}(1,1)$ model to the residuals.

\footnotetext{
11 The choice of the AR and the MA orders is suggested by the relevant literature, while the degree of differencing is set equal to 1 as the data series of interest are integrated of order one $(\sim \mathrm{I}(1))$.
} 
The heteroscedasticity checks on the ARIMA residuals constitute a deviation from the reference literature, as we deem this further step to be helpful in improving the robustness of the resulting estimates vis-à-vis possible misspecifications. Moreover, this procedure is useful in addressing the shortcomings related to the $\operatorname{GARCH}(1,1)$ procedure explained above. For these reasons, we prefer the ARIMA estimates and use it as the benchmark measure in our regression analysis.

\section{B. Evolution of Volatility over Time}

Using the volatility estimates from the three measures, this section considers how the volatility of capital flows has evolved over time. We first look at the aggregate flows both globally and for AEs and EMDEs separately. ${ }^{12}$ We then study the evolution of volatility for the single components of gross inflows in EMDEs only.

\section{Total flows}

When discussing volatility, policymakers are interested in both the levels as well as the changes in volatility. Using our measures, we shed light on both aspects in this section.

Figures 4a, 5a and 6a show the evolution of volatility of net flows for World, AEs and EMDEs respectively, using the three different measures. As discussed in section IV.A, the charts clearly show that RW underestimated the spike in volatility at the onset of the crisis and overestimated the fall in volatility following the end of the crisis. This underscores the need for going beyond the crude RW measure. Comparing the three measures, the GARCH estimates tend to lag slightly behind the RW and the ARIMA, and are on average higher than the estimates produced by the other two approaches. However, broadly speaking, the three estimates show similar results.

Comparing the levels of volatility across income groups, the charts suggest that net flows to EMDEs are more volatile than net flows to AEs. As discussed in the previous section, gross outflows tend to dampen the impact of gross inflows on net flows in AEs but not in EMDEs, resulting in higher volatility for net flows in EMDEs compared to AEs. Looking at the volatility of gross inflows and gross outflows in EMDEs separately, Figures $6 \mathrm{~b}$ and $6 \mathrm{c}$ show that the volatility of inflows is on average higher than outflows, thereby driving up the volatility of net flows.

An interesting question is how the volatility has fared since the GFC, especially in EMDEs. The charts show that, barring several spikes in AEs and EMDEs, the biggest one corresponding to the GFC, the current level of volatility is comparable to the pre-crisis average. However, EMDEs

\footnotetext{
${ }^{12}$ In this section, the aggregates represent total capital flows divided by total GDP. As a robustness check, volatility estimates have been computed for weighted aggregate capital flows series, using two different sets of weights. Notably, the first set is given by domestic GDP as a share of group GDP, while the second consists of each country's International Investment Position (IIP), measured as the sum of assets and liabilities, divided by the group's IIP. The series are available upon request. The final results are not qualitatively different from the outcome observed for unweighted data.
} 
volatility has been prone to bouts, as it has risen during global risk off episodes. In particular, the volatility spiked up during the taper tantrum episode. These bouts of increase in volatility thus remain a policy challenge for EMDEs, particularly in the current context of capital flow slowdown (IMF 2016), where even small swings in flows can lead to substantial net outflows or sudden stops. In fact, when adjusted for the level of flows, volatility has either increased or stayed at the same pre-crisis levels (Appendix D) and, hence, remains a major concern.
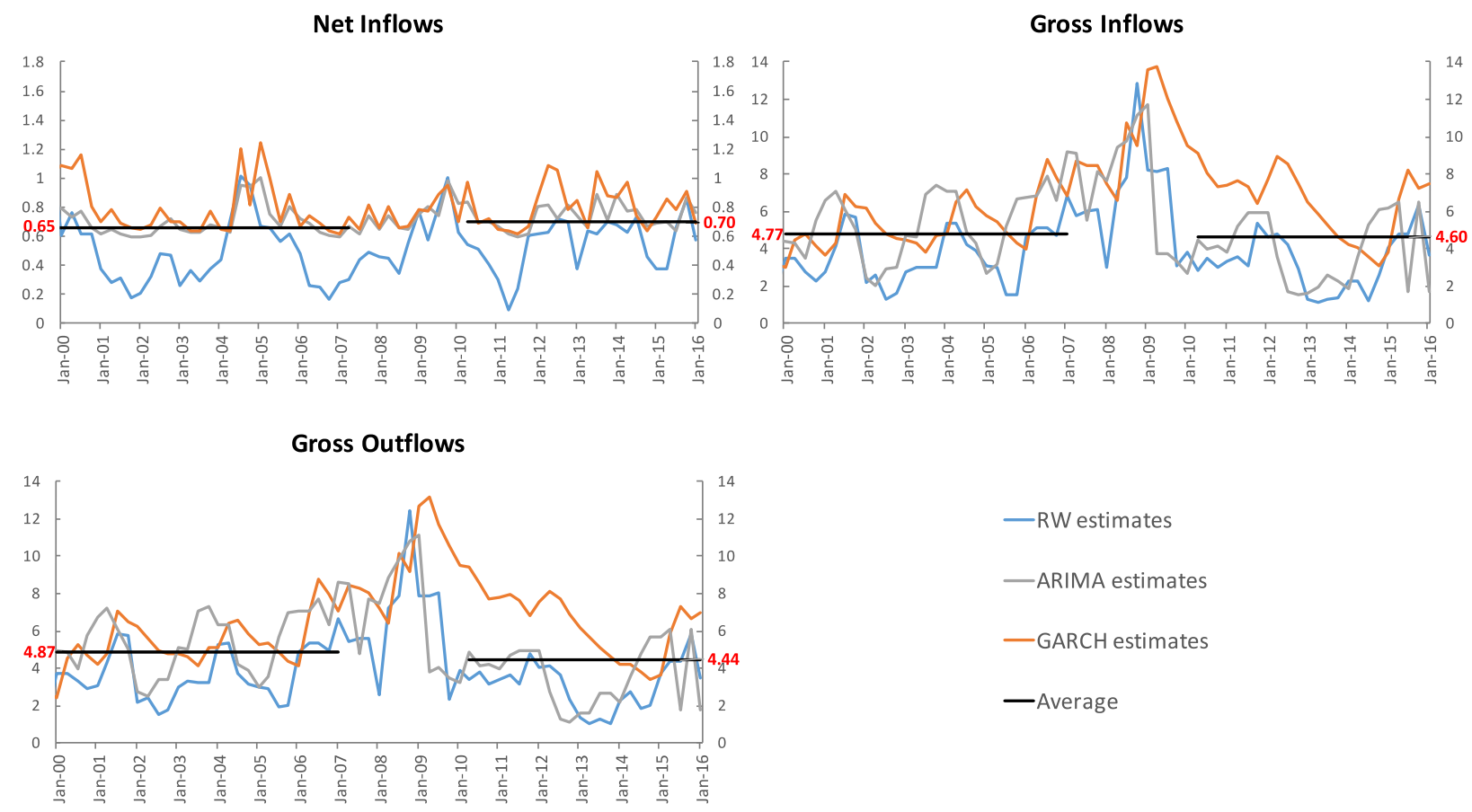

Figure 4: Evolution of the volatility of capital flows for the World aggregate. Notes: Measures are expressed as \% share of total GDP. Source: IMF, International Financial Statistics, authors' computations. 
Net Inflows

Gross Inflows
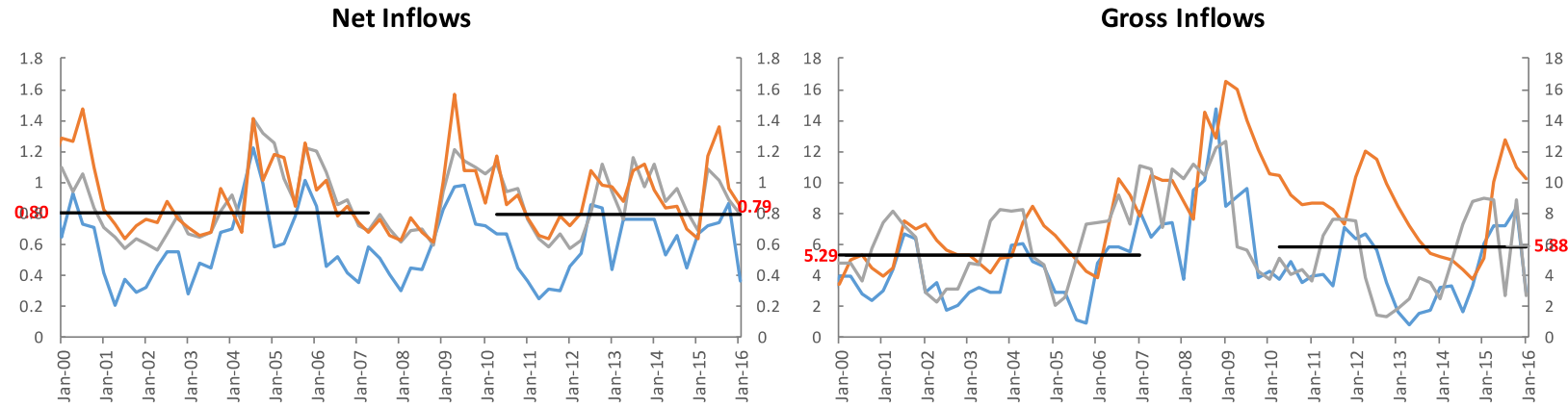

Gross Outflows
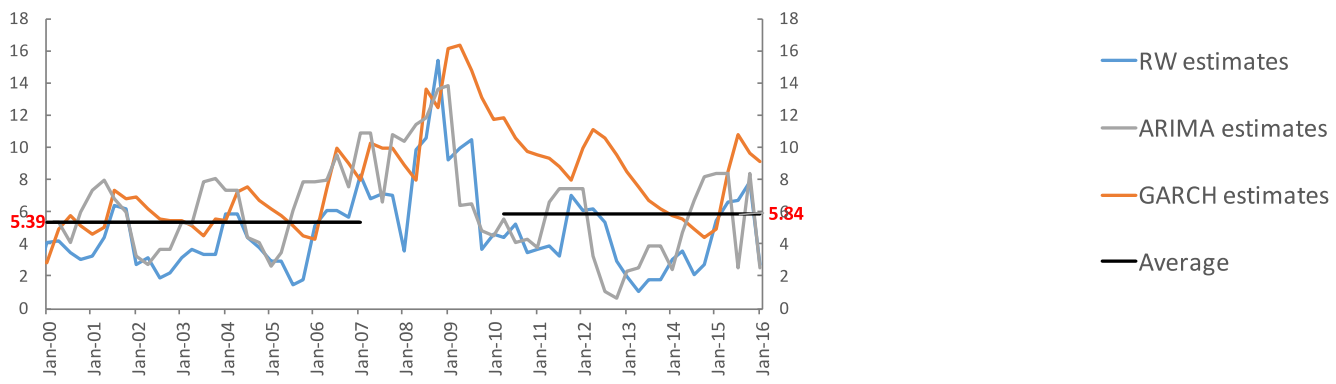

Figure 5: Evolution of the volatility of capital flows in AEs. Notes: Measures are expressed as \% share of total GDP. Source: IMF, International Financial Statistics, authors' computations.

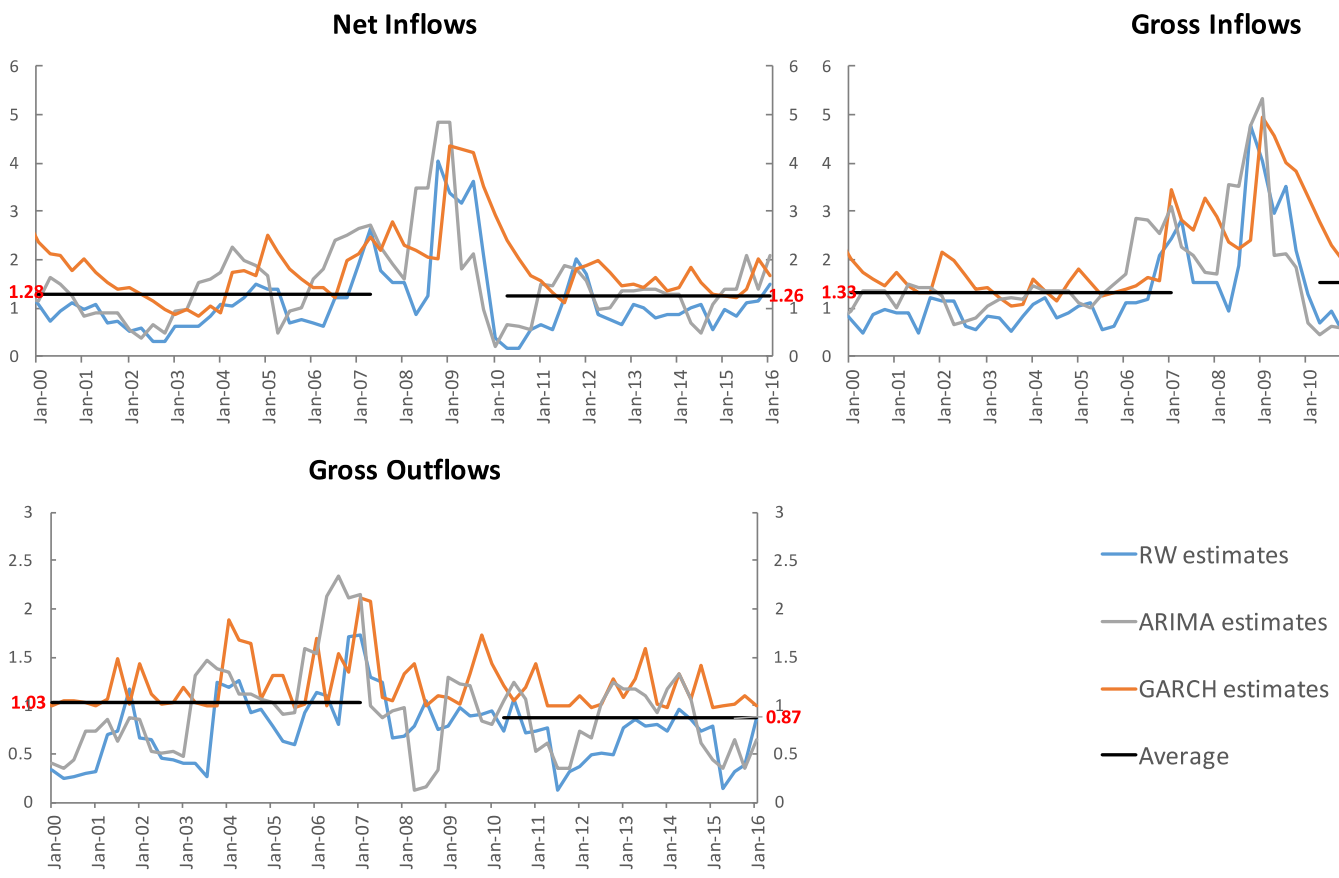

Figure 6: Evolution of the volatility of capital flows in EMDEs. Notes: Measures are expressed as $\%$ share of total GDP. Source: IMF, International Financial Statistics, authors' computations. 
Given its size, China could have an impact in the overall capital flow volatility of EMDEs. Charts in Appendix E display the volatility of capital flows over time for World and EMDEs, excluding China. Broadly speaking, the evolution is not very different when China is excluded. However, the increases in volatility observed more recently are not as pronounced. The subsequent charts in Appendix E show that this discrepancy is associated with the volatility of other investments.

\section{Statistical tests}

We perform some tests to detect whether the mean value of the estimates has significantly changed after the GFC compared to the pre-crisis period. Table 2 reports the results for the Geweke's separated partial means test performed over three groups (global, AEs and EMDEs) and the three different measures. ${ }^{13}$

Table 2 shows that the null hypothesis of equal mean values before and after the crisis is almost always rejected at $5 \%$ or $10 \%$ significance levels, indicating that there has been some shift in volatility, albeit very small in magnitude, since the GFC. There are, however, some results that show no statistical difference in mean values, notably for net flows in World (RW measure) and net flows in AEs (GARCH estimator). The same holds for the GARCH volatility of both gross and net inflows in EMDEs.

\begin{tabular}{|cccc|ccc|ccc|}
\hline \multicolumn{4}{c}{ RW } & \multicolumn{3}{c|}{ GARCH } & \multicolumn{3}{c|}{ ARIMA } \\
\hline Global & GIs & GOs & NIs & GIs & GOs & NIs & GIs & GOs & NIs \\
Statistic & 9.18 & 6.83 & 1.19 & 62.44 & 53.39 & 3.66 & 20.36 & 15.27 & 3.05 \\
P-value & 0.00 & 0.01 & 0.28 & 0.00 & 0.00 & 0.06 & 0.00 & 0.00 & 0.08 \\
& & & & & & & & & \\
AEs & & & & & & & & & \\
Statistic & 20.99 & 21.04 & 15.17 & 79.31 & 86.76 & 0.68 & 17.69 & 17.61 & 6.88 \\
P-value & 0.00 & 0.00 & 0.00 & 0.00 & 0.00 & 0.41 & 0.00 & 0.00 & 0.01 \\
& & & & & & & & & \\
EMEs & & & & & & & & & \\
Statistic & 7.89 & 15.84 & 24.60 & 0.99 & 12.38 & 0.06 & 6.51 & 15.10 & 27.76 \\
P-value & 0.00 & 0.00 & 0.00 & 0.32 & 0.00 & 0.80 & 0.01 & 0.00 & 0.00 \\
\hline
\end{tabular}

Table 2: results of the Geweke's separated partial means test for World, AEs and EMDEs aggregates, RW, GARCH and ARIMA volatility estimates. Notes: GIs: Gross Inflows; GOs: Gross Outflows; NIs: Net Inflows. Statistics are based on two separate means $(p=2)$ and covariance functions tapered at $2 \%$; the limiting distribution is a chi-squared with $1 \mathrm{dof} ; \mathrm{H}_{0}$ : means are equal, $\mathrm{H}_{1}$ : means are different.

Therefore, conclusions about evidence of a decrease or increase in volatility owing to the GFC depend on the type of flows targeted by the analysis and the methodology adopted. Broadly speaking, we can say that, in the aftermath of the financial crisis, EMDEs have experienced a slight increase in the volatility of gross inflows and a slight decrease in the volatility of gross outflows,

\footnotetext{
${ }^{13}$ Refer to Geweke (2005). This test allows us to control for autocorrelation in the volatility estimates (see Appendix C).
} 
on average by $0.2 \%$ and $0.16 \%$ of GDP respectively. These two effects have concurred to slightly decrease the volatility of net inflows by an average of $0.02 \%$ of GDP.

\section{Individual components}

Even if EMDEs are moving towards a greater financial integration, they still attract inflows from foreign investors that more than outweigh investments of domestic agents abroad. ${ }^{14}$ Therefore, the paper from here focuses primarily on the analysis of the volatility and its determinants for gross (or net) inflows, as evidence suggests these are of greater importance for EMDEs. ${ }^{15}$ Figure 7 shows the evolution of volatility for individual components of EMDEs gross inflows. Portfolio and other investment flows are around two and four times, respectively, more volatile than FDI. Among portfolio flows, portfolio debt is more volatile than portfolio equity. These results are in line with literature showing that equity flows, both FDI and portfolio equity, are generally less volatile.

Looking at the evolution of each instrument, the volatility estimates for FDI present a clear-cut upward trend before the GFC and a downward trend afterwards, particularly for GARCH and ARIMA estimates. For portfolio, GARCH and ARIMA estimates are higher than RW. Broadly speaking, there is not a defined trend and estimates tend to hover around the long-run averages. However, the volatility for this instrument is lower in the subsample 2009-2016. As to portfolio equity, the ARIMA and RW estimates highlight a slight upward trend for volatility until the GFC and a downward trend thereafter. Finally, other investments display the highest volatility estimates among all instruments. Even in this case, GARCH produces higher values than the other approaches.

The volatility of individual components can help track down the dynamics underlying the evolution of volatility of total capital flows. Figure 8 plots the ARIMA estimates of total inflows and the individual components. Positive changes in volatility are, broadly speaking, driven primarily by increases in the volatility of other investments, followed by the volatility of portfolio instruments (debt primarily). In the next section, we analyze in detail the volatility of the subcomponents of other investments.

Even if, in certain cases, volatility seems to have declined over time, the results can be different when estimates are adjusted by the levels (the idea is almost similar to computing the coefficient of variation). In particular, though net FDI volatility has gone down significantly for EMDEs, it is rising when adjusted for the levels (Appendix D, Figures 1 and 2). Similarly, net portfolio adjusted volatility has also increased in more recent periods.

\footnotetext{
14 The differences in the behavior of net flows between AEs and EMDEs is also due to the fact that while in AEs capital flows are used for both risk-sharing and portfolio diversification, for EMDEs, by contrast, capital flows are not only instrumental for risk-sharing, but also to have access to greater external financing (see Canuto and Ghosh (2013), Ch. 3).

${ }^{15}$ Measures for gross outflows and net inflows, however, are available upon request. Broadly speaking, the volatility measures for gross inflows and net inflows are similar, but that of gross outflows is different.
} 

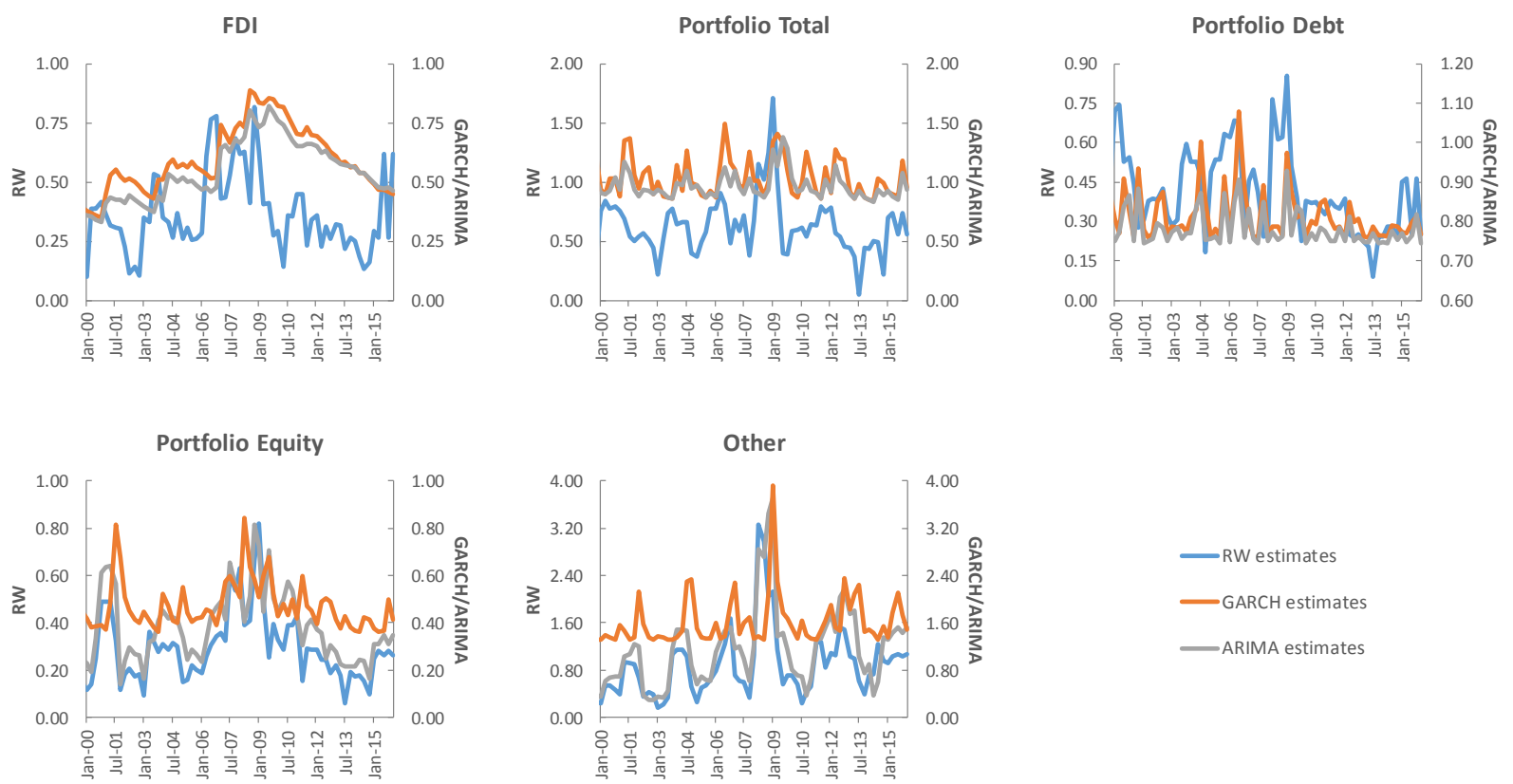

Figure 7: Evolution of the volatility of gross capital inflows for EMDEs by components. Note: measures are expressed as \% of group GDP. Source: IMF, International Financial Statistics, authors' computations.

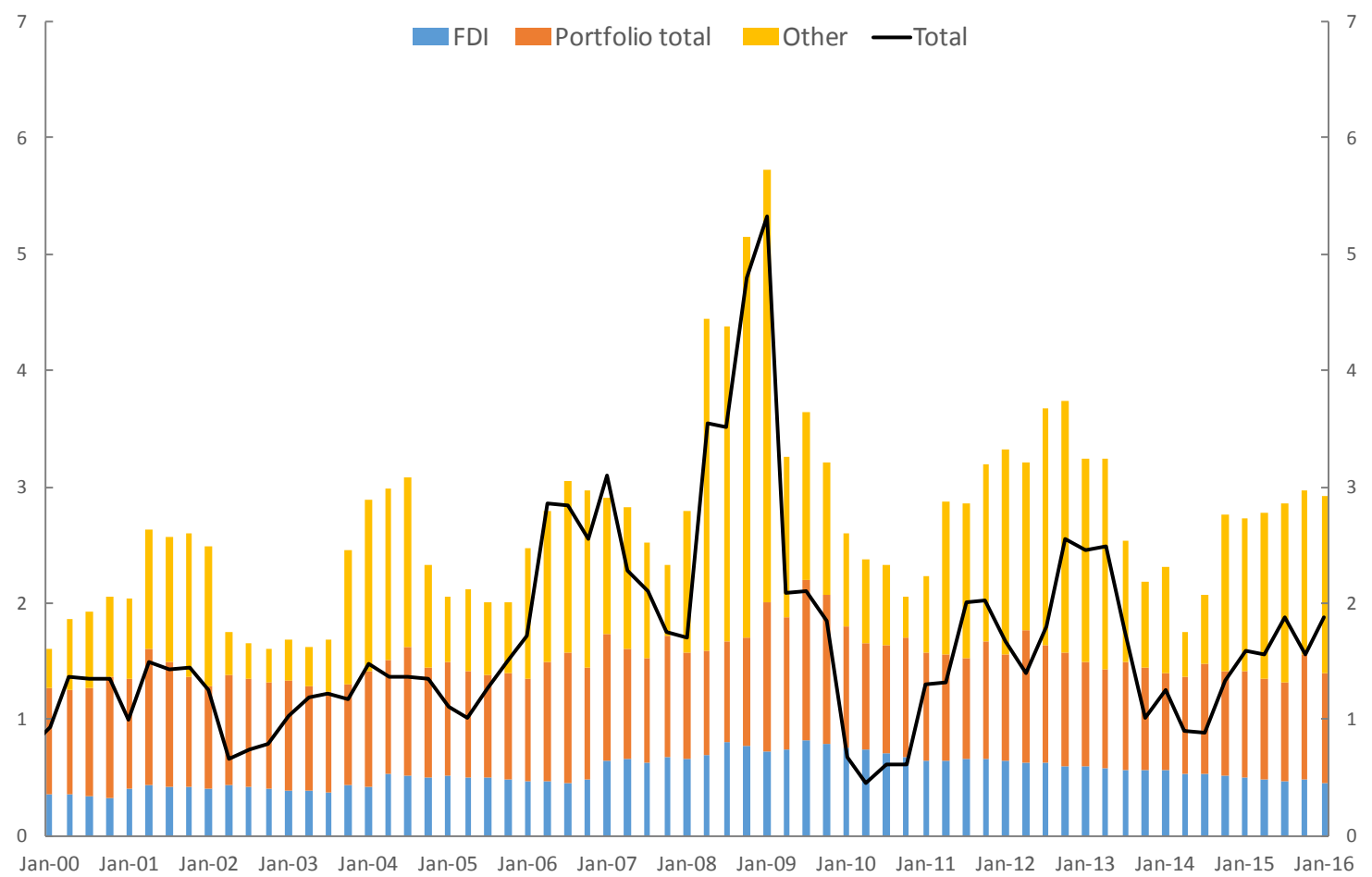

Figure 8: Evolution of the ARIMA volatility estimates of aggregate gross capital inflows and their components in EMDEs. Notes: measures are expressed as \% of group GDP. Source: IMF, International Financial Statistics, authors' computations. 


\section{Statistical tests}

\begin{tabular}{|lccccc|}
\hline & FDI & Portfolio & Port. debt & Port. equity & Other \\
\hline \hline$R W$ & & & & & \\
Statistic & 153.78 & 4.18 & 17.06 & 1.90 & 10.76 \\
P-value & 0.00 & 0.04 & 0.00 & 0.17 & 0.00 \\
& & & & & \\
GARCH & & & & & \\
Statistic & 136.40 & 2.60 & 5.99 & 2.99 & 5.06 \\
P-value & 0.00 & 0.11 & 0.01 & 0.08 & 0.02 \\
& & & & & \\
ARIMA & & & & & \\
Statistic & 233.30 & 2.86 & 4.52 & 3.21 & 13.81 \\
P-value & 0.00 & 0.09 & 0.03 & 0.07 & 0.00 \\
\hline
\end{tabular}

Table 3: results of the Geweke's separated partial means test for EMDEs gross inflows, RW, GARCH and ARIMA volatility estimates. Notes: Statistics are based on two separate means $(\mathrm{p}=2)$ and covariance functions tapered at $2 \%$; the limiting distribution is a chi-squared with 1 dof; $\mathrm{H}_{0}$ : means are equal, $\mathrm{H}_{1}$ : means are different.

Table 3 reports the partial means test results for gross inflows in EMDEs, broken down by instruments. While the null hypothesis of equal means is rejected for FDI, portfolio debt and other investments across all the estimators, the volatility of portfolio inflows (GARCH) and the volatility of portfolio equity flows (RW) have means that are not statistically different before and after the GFC. Using ARIMA estimates, we can conclude that, in the aftermath of the financial crisis, EMDEs have experienced a change in the volatility of FDI, portfolio and other investments, on average, by $0.086 \%,-0.014 \%$ and $0.249 \%$ of GDP respectively.

\section{Delving Deeper into Other Investment Flows}

Even though other investments are, on average, smaller in levels than equity instruments like FDI, the previous section shows that they are very relevant in determining the volatility developments for capital inflows to EMDEs. Hence, this section looks in detail at the individual components of other investment flows. Notably, other investment flows can be classified in: i) bank flows; ii) private non-bank flows; iii) official sector flows.

\section{Composition of Other Investment Flows}

Before discussing the volatility measures, Figure 9 depicts the evolution of other gross inflows and shows their composition (in levels), by disentangling between flows to the public sector and flows to the private sector. Private flows - which make up most part of the aggregate other investment flows - reversed and experienced a temporary stop during the GFC, which resulted in the sudden stop of aggregate gross inflows to EMDEs over the same period. After the GFC, the level of flows to private sector appears markedly lower than before, with two episodes of reversal experienced in 2015 and 2016. This behaviour broadly coincides with the general slowdown in aggregate capital flows to EMDEs after the crisis. 
Figure 10 shows the evolution of other gross inflows by decomposing the flows to private sector into flows to banks and non-banking companies. Flows to countries for which data are not classified between banking and non-banking sectors are not included in these aggregates. The "private - not classified" flows include flows to countries for which data are not classified between banking and non-banking flows (see Figure 10). Before the crisis, most of other flows consisted of private flows to both banking and non-banking sectors, which contributed to the surge of gross capital inflows to EMDEs over the same period. On the other hand, after the GFC, both these types experienced a decrease in volumes and, in certain periods, they almost disappeared from the capital account (e.g. in the second half of 2009).

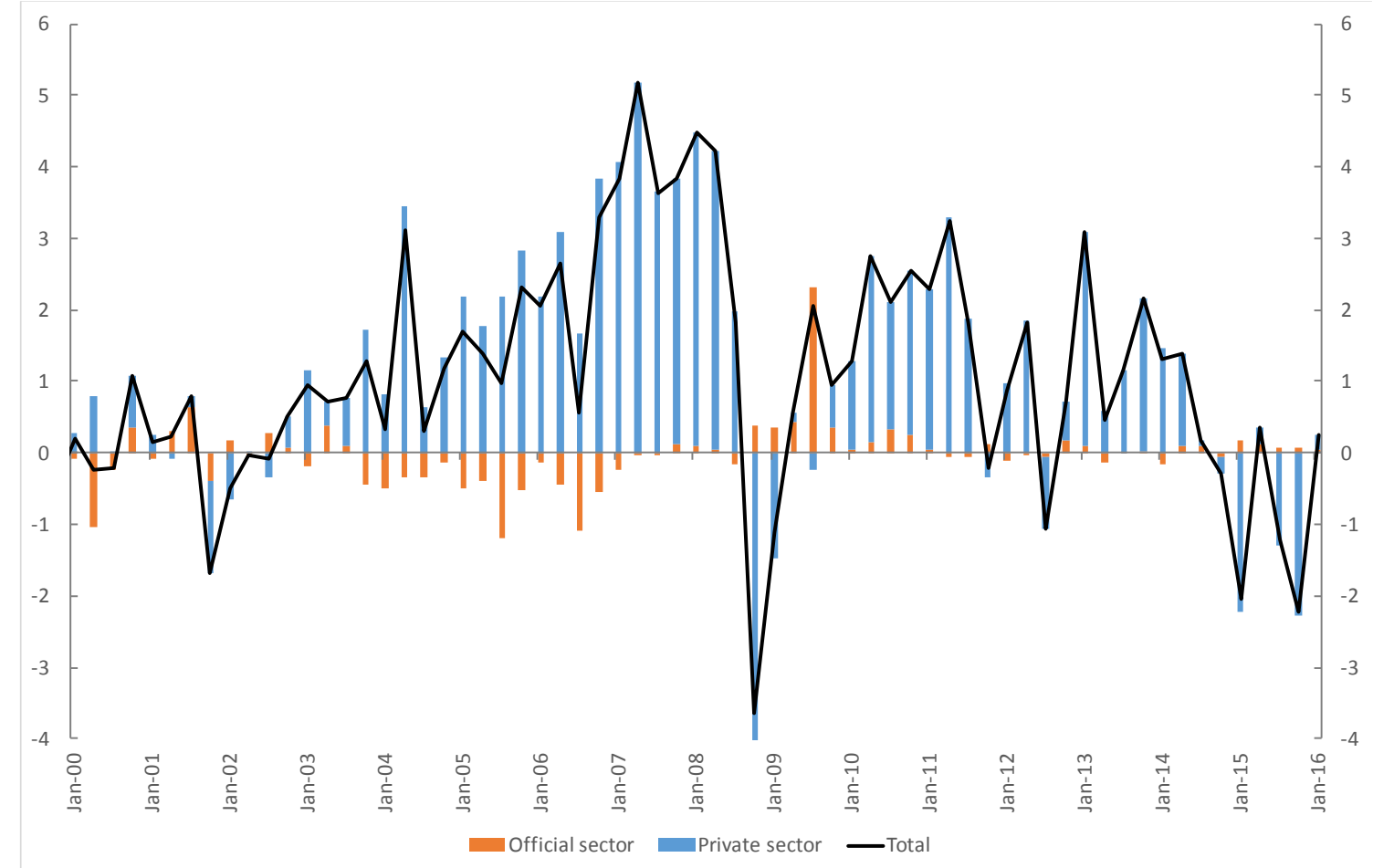

Figure 9: Other gross capital inflows in EMDEs by sector. Notes: measures are expressed as \% share of group GDP; private sector flows are the sum of banking flows and flows to non-banking companies. Source: IMF, International Financial Statistics, authors' computations. 


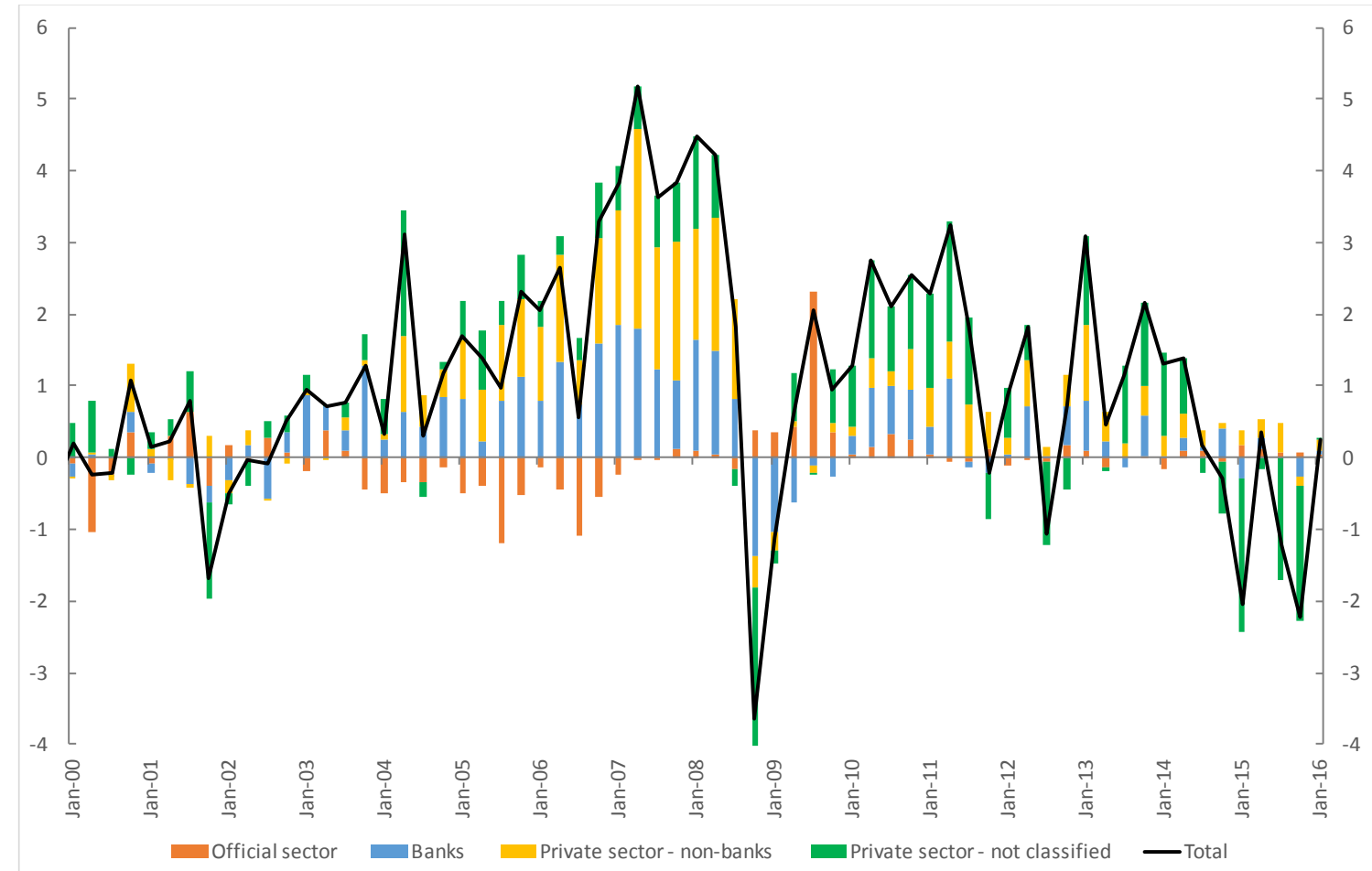

Figure 10: Other gross inflows in EMDEs by sector. Notes: measures are expressed as \% share of group GDP. Source: IMF, International Financial Statistics, authors' computations.

\section{Volatility of Other Investment Flows}

Figure 11 below shows the evolution of volatility for the other gross inflows ${ }^{16}$ broken down by their subcomponents. It can be noticed that the volatility of private flows is much higher than the volatility of flows through the official sector. The latter, indeed, after a spike during the crisis, has stabilized around a level which is close to 0.

In the private sector, flows to banks display a slight decrease towards the end of the time period considered, while the volatility of flows to the non-banking sector has stabilized around a lower long-run average after the crisis. All in all, we can say that the volatility of other investments is almost completely driven by the volatility of private flows and, for these latter ones, volatility is around equally distributed across the banking and non-banking sectors.

\footnotetext{
${ }^{16}$ Estimates for net inflows and gross outflows are available upon request.
} 

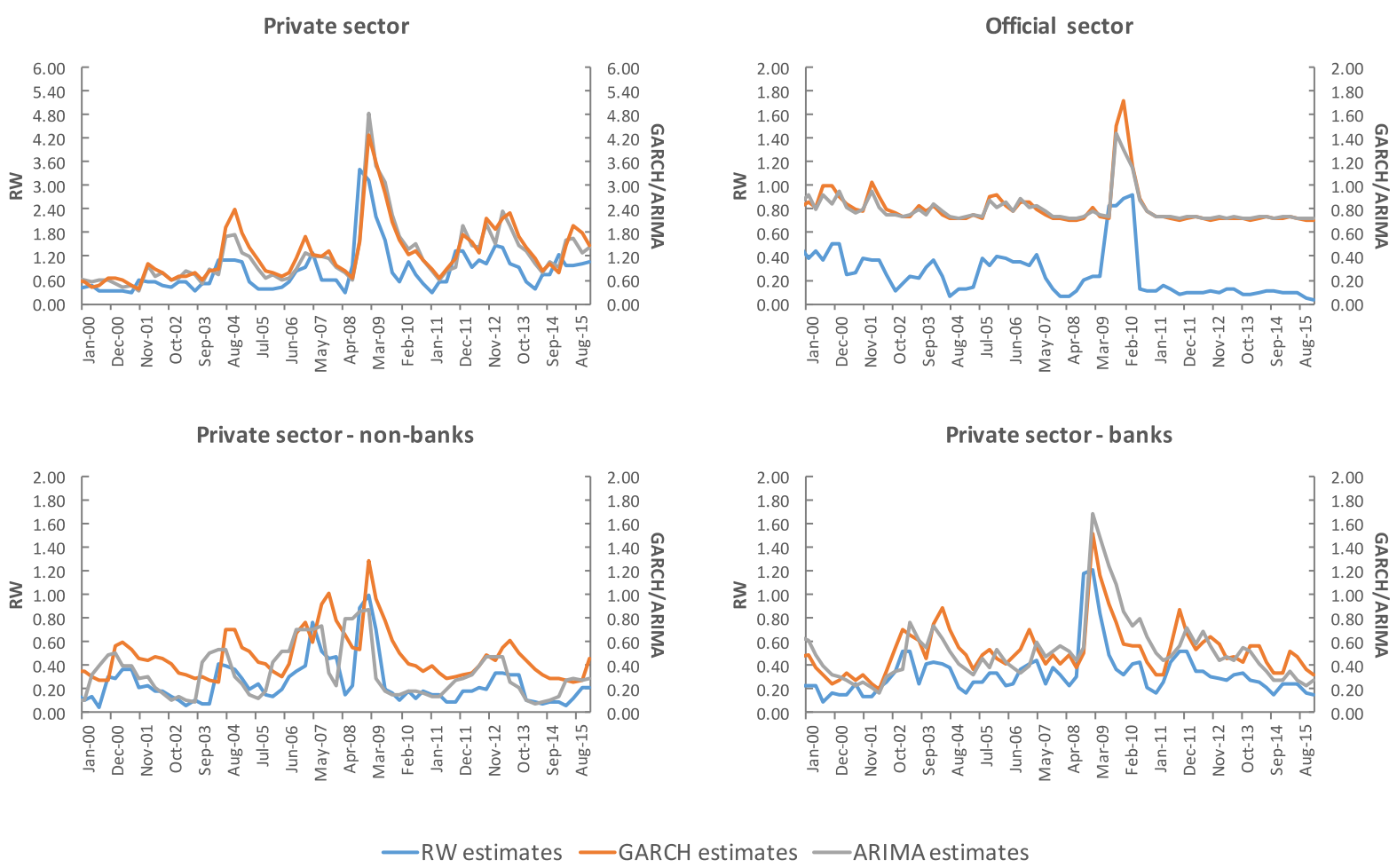

Figure 11: Volatility estimates for other gross capital inflows in EMDEs by components. Notes: measures are expressed as \% share of group GDP; aggregates for flows to the banking and nonbanking sector do not include non-reporting countries. Source: IMF, International Financial Statistics, authors' computations.

\section{Volatility Measures for Individual countries}

Given that the previous section shows how the three approaches produce very similar estimates across different types of flows and instruments, the analysis carried out in the remainder of the paper will be based on our preferred ARIMA estimates only.

Apart from computing volatility of aggregate series, the same three measures are used to calculate the volatility for the individual EMDE countries. The volatility measures of individual countries are useful for several reasons. First, they can be important tools in policy discussions related to understanding and mitigating undesirably high volatility in a particular country. Second, the volatility measures of single components will inform policymakers about which instruments they should monitor more closely. Third, these measures can be extremely useful in studies and research geared towards understanding and comparing volatility across countries and regions, as they can shed light on the instruments responsible for possible shifts in volatility. Fourth, as shown in our subsequent analysis, the estimates of individual countries can help understand the relationship between EMDEs and AEs capital flow volatility, as well as the determinants of EMDEs capital flow volatility. 
Figure 12 shows the median values of volatility estimates for each country by instruments for gross inflows. ${ }^{17}$ The green bar represents the median value for each group. As expected, median volatility is higher for portfolio flows than other types, in line with the findings witnessed for aggregate series. The median variance of overall portfolio flows is lower than the sum of variances of portfolio debt and portfolio equity flows, suggesting that there might be a negative correlation between these two subcategories. These charts also highlight the presence of a great degree of heterogeneity across countries, that is concealed when looking at the trend of aggregate flows. For instance, while the conclusion that, on median, portfolio flows are much more volatile than FDIs, however there are some countries (e.g., Chile) whose FDIs are much more volatile than portfolio inflows, or for which, at least, the volatility measures are of comparable magnitude across the two instruments (e.g., Latvia and Kazakhstan).

In addition, Figure 13 displays the empirical distributions of the median volatilities for each instrument. The density functions of the median volatilities are a mixture of multiple distributions and this suggests the presence of important outliers in the series, something which is also underlined by the positive skewness and the high kurtosis of the density functions. ${ }^{18}$ In particular, the distributions of median volatilities for portfolio and portfolio debt are shifted to the right, compared to the other ones, indicating how median volatilities are generally higher for these types of instruments. Moreover, the kurtosis of the same distributions is the highest among all the instruments (closely followed by other investments). This indicates that the probability of observing extreme values (outliers) is greater in these cases than for FDI or portfolio equity, making the aggregate results more prone to be influenced by extreme observations.

\footnotetext{
17 The underlying time series for each country is available upon request. In addition, the time series for volatility of net and gross outflows for each country are also available upon request.

18 The skewness values are 1.0770, 2.8565, 2.8875, 1.2858, 2.1120 for FDI, portfolio, portfolio debt, portfolio equity and other investments respectively. The kurtosis values are 3.3431, 14.3172, 14.0942, 4.1295 and 8.5991 for FDI, portfolio, portfolio debt, portfolio equity and other investments respectively.
} 
FDI
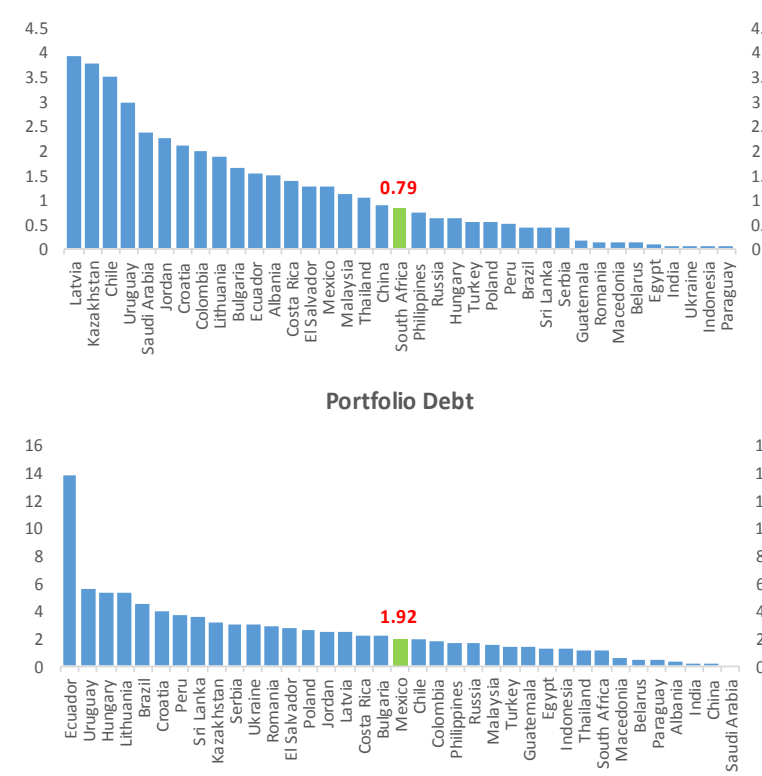

Other

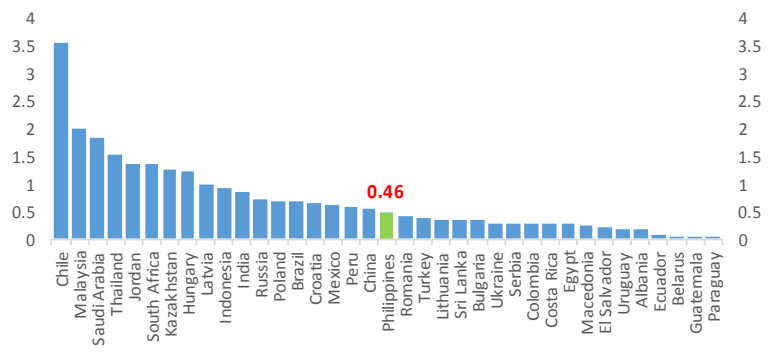

Portfolio

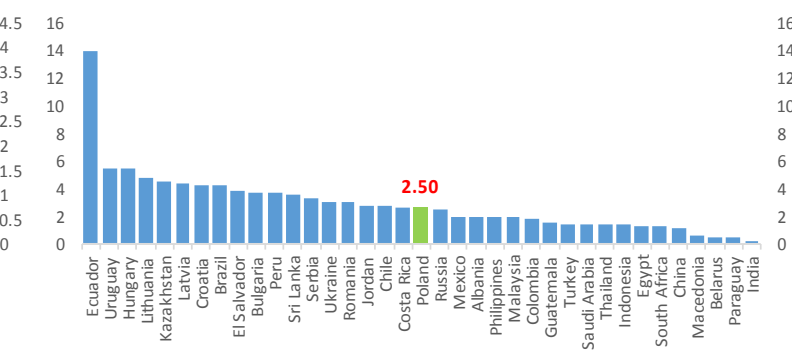

Portfolio Equity

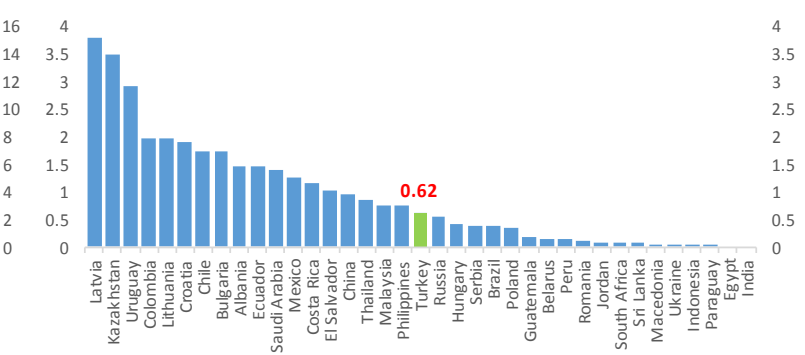

Figure 12: Medians of ARIMA volatility estimates for gross inflows by instrument and across countries. Notes: measures are expressed as \% of GDP. Source: IMF, International Financial Statistics, authors' computations. 


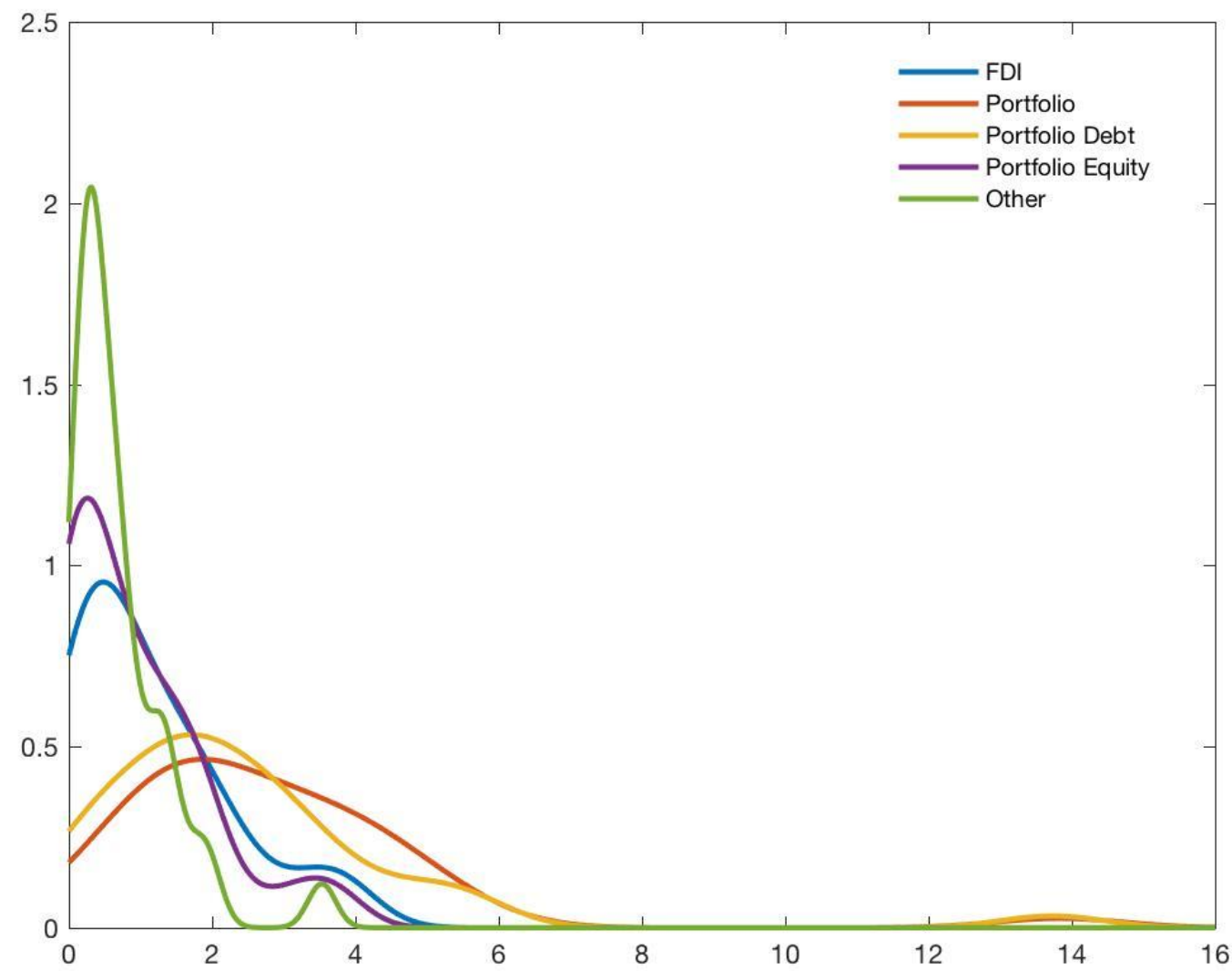

Figure 13: Cross-sectional Empirical Probability Density Functions of median ARIMA volatility estimates for gross inflows by instrument. Source: IMF, International Financial Statistics, authors' computations.

Figure 13 provides a static picture of how median volatility is distributed across countries. In order to get a better sense of how capital flow volatility can react to global shocks and how risk is redistributed across regions thereafter, figures 14-19 display a heat map for the ARIMA volatility estimates before and after the GFC, for gross inflows and other gross private inflows, across all the countries (AEs and EMDEs) in the sample. ${ }^{19}$

\footnotetext{
${ }^{19}$ We just display results for these two types, because, as already mentioned previously, gross inflows are the main components of the financial account of EMDEs, while other investments essentially drove the capital flows slowdown in the aftermath of the GFC. However, charts for other types of flows and instruments are available upon request.
} 


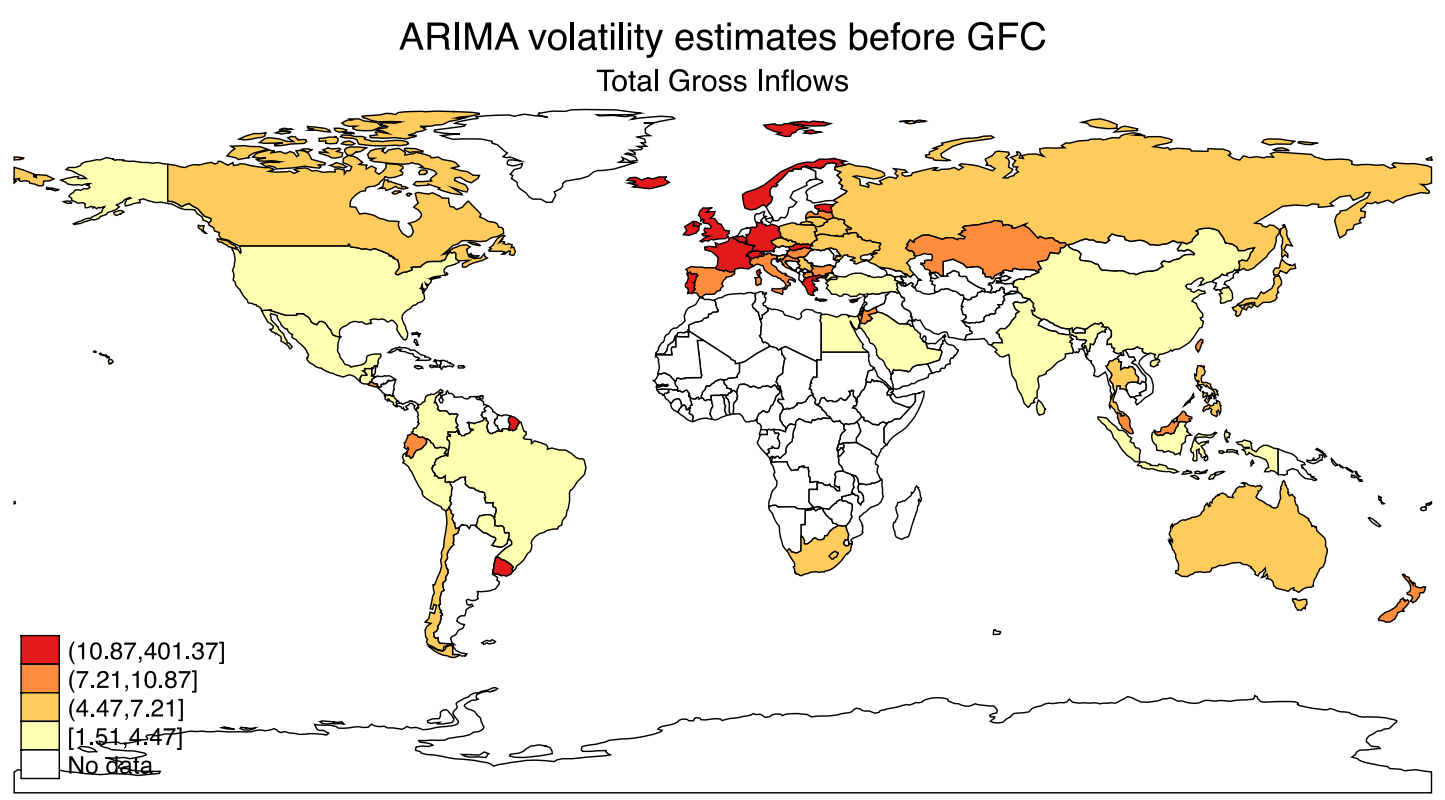

Figure 14: ARIMA volatility estimates for gross inflows by country over the period 2000Q12007Q2. Source: IMF, International Financial Statistics, authors' computations.

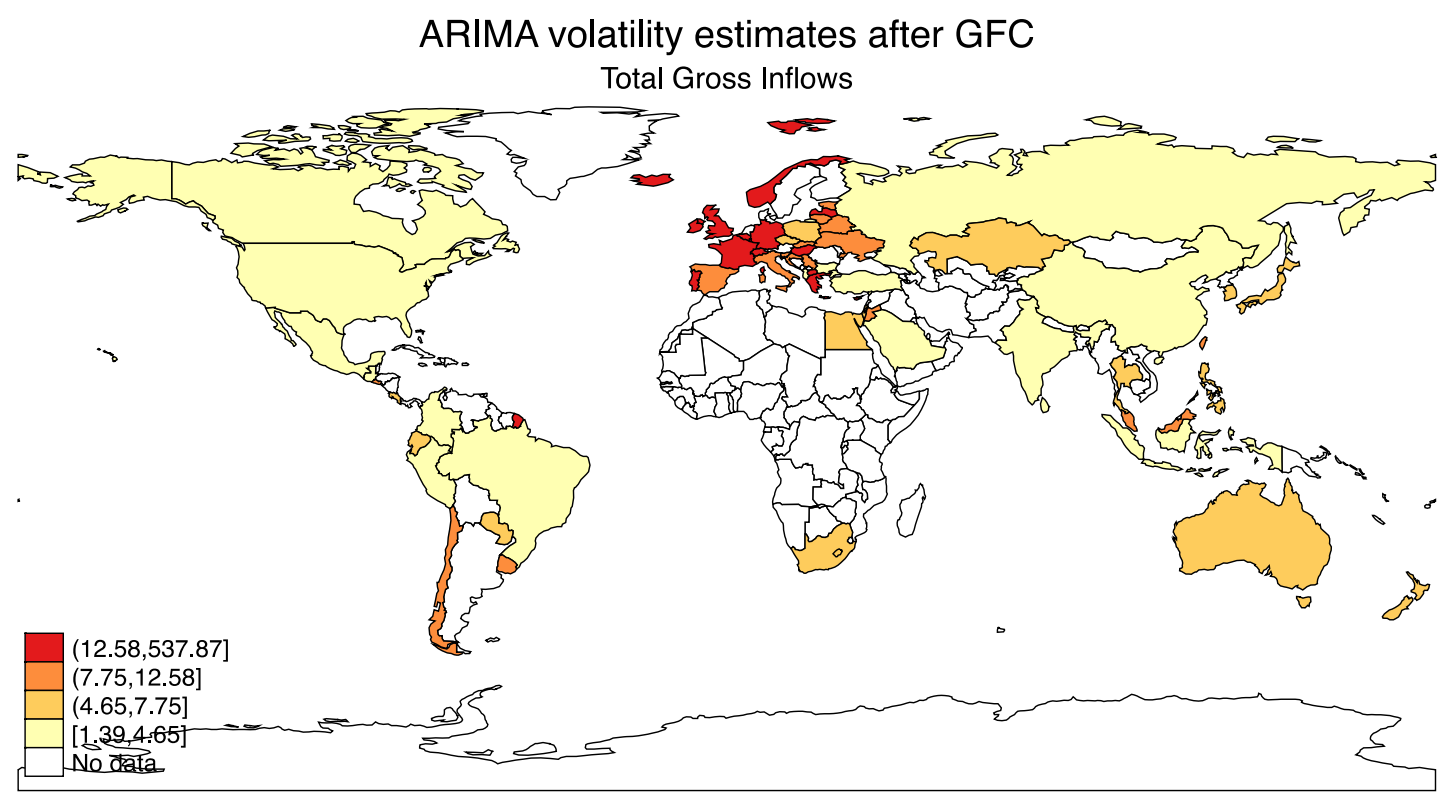

Figure 15: ARIMA volatility estimates for gross inflows by country over the period 2009Q32016Q1. Source: IMF, International Financial Statistics, authors' computations.

The heat maps suggest that the volatility of total gross inflows has remarkably decreased since GFC in countries like Canada and Russia, as well as the smaller Latin America economies. Although the rough visual comparison across the pre and post-crisis periods does not seem to display much change, it can be noticed from the boundary values that define the intervals (in the legend) that there has been an upward shift in the entire distribution, meaning that the median 
value of volatility in the sample has increased over time. So, in spite of few single-case exceptions, we can say that, on average, volatility of gross inflows has increased after the GFC. ${ }^{20}$

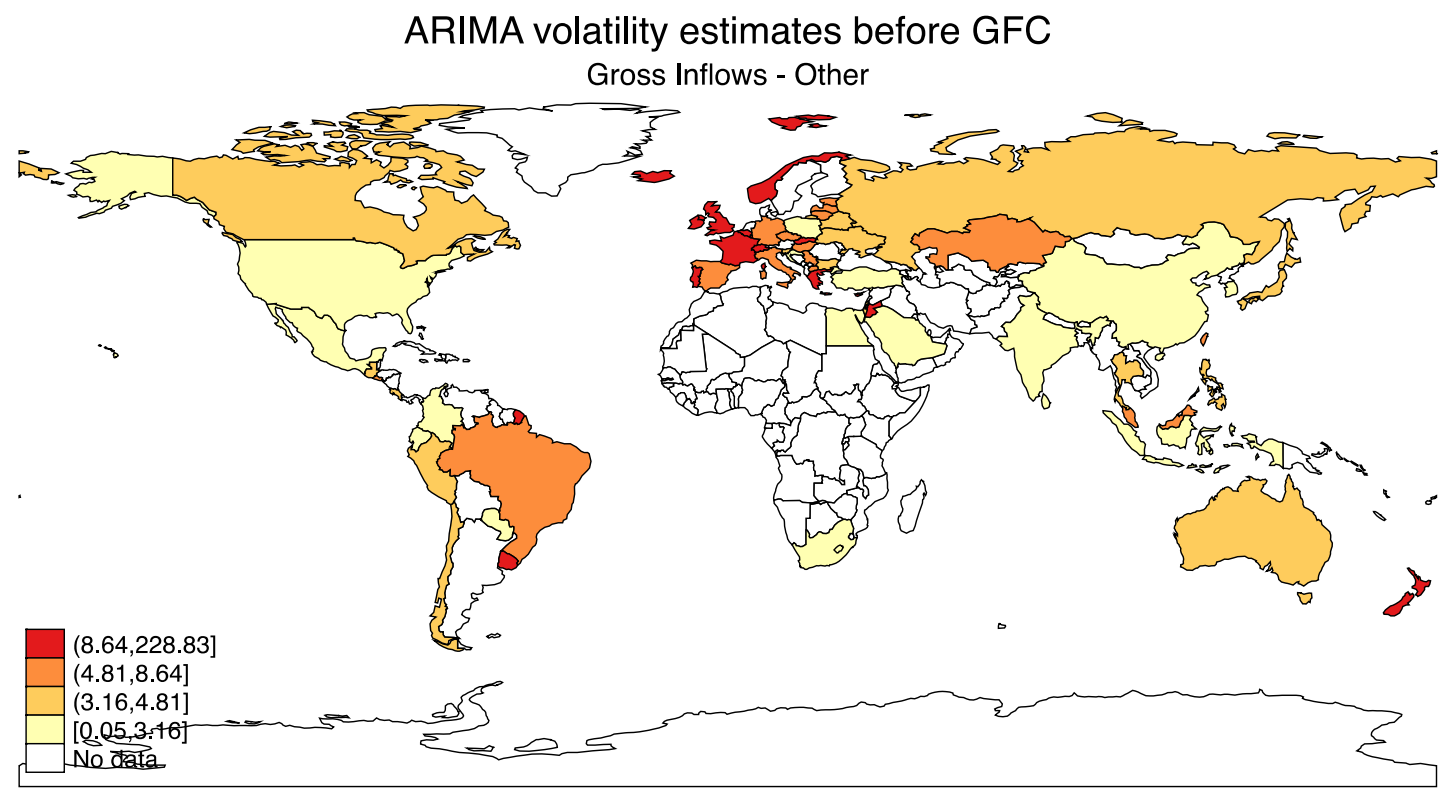

Figure 16: ARIMA volatility estimates for other gross inflows by country over the period 2000Q12007Q2. Source: IMF, International Financial Statistics, authors' computations.

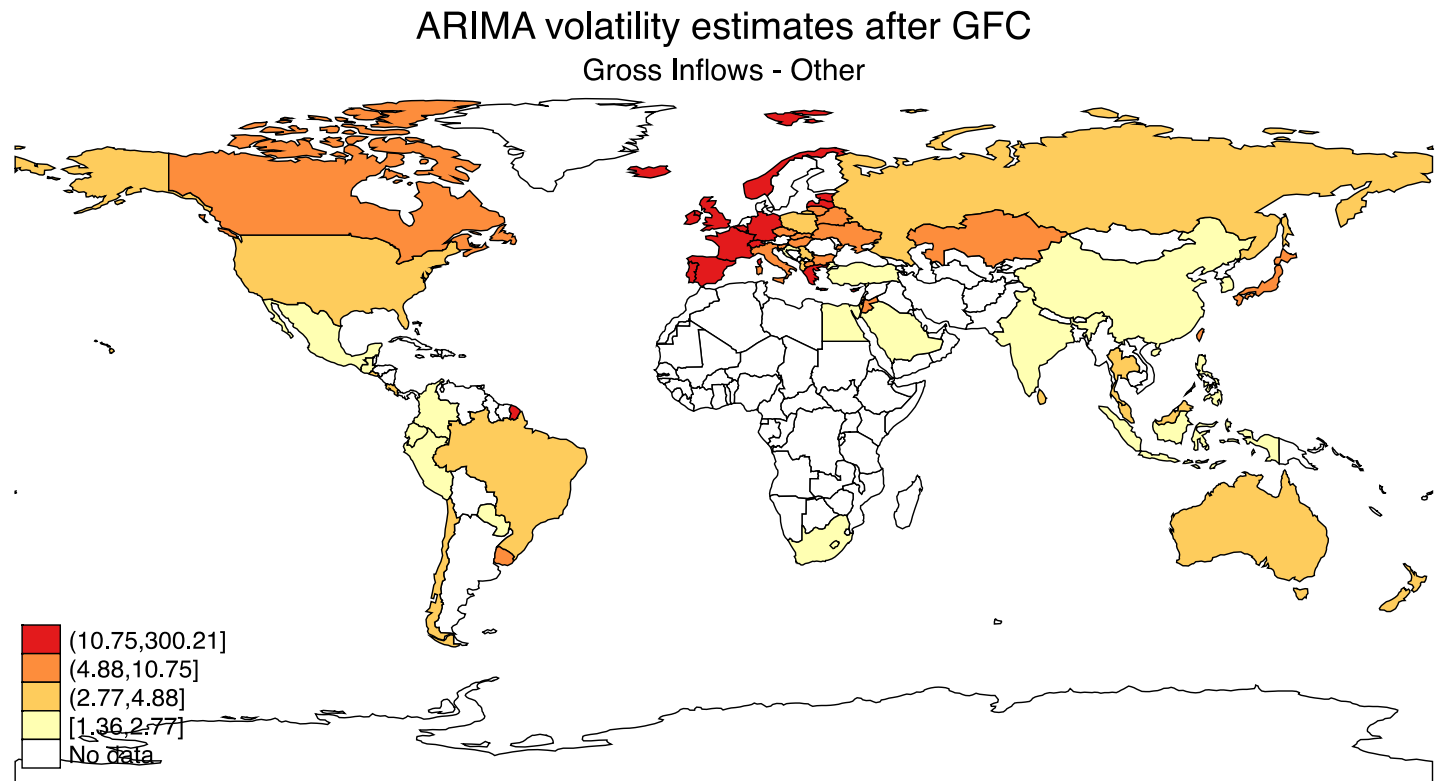

Figure 17: ARIMA volatility estimates for other gross inflows by country over the period 2009Q32016Q1. Source: IMF, International Financial Statistics, authors' computations.

${ }^{20}$ This conclusion holds also if outliers are excluded from the sample. 
Comparing the pre and post-GFC periods, the volatility of other investment has somewhat decreased in some Latin American economies, while it has remarkably increased in North America and Europe. In Asia, the picture does not seem to have changed much, except for Japan, whose other inflows volatility has slightly increased.

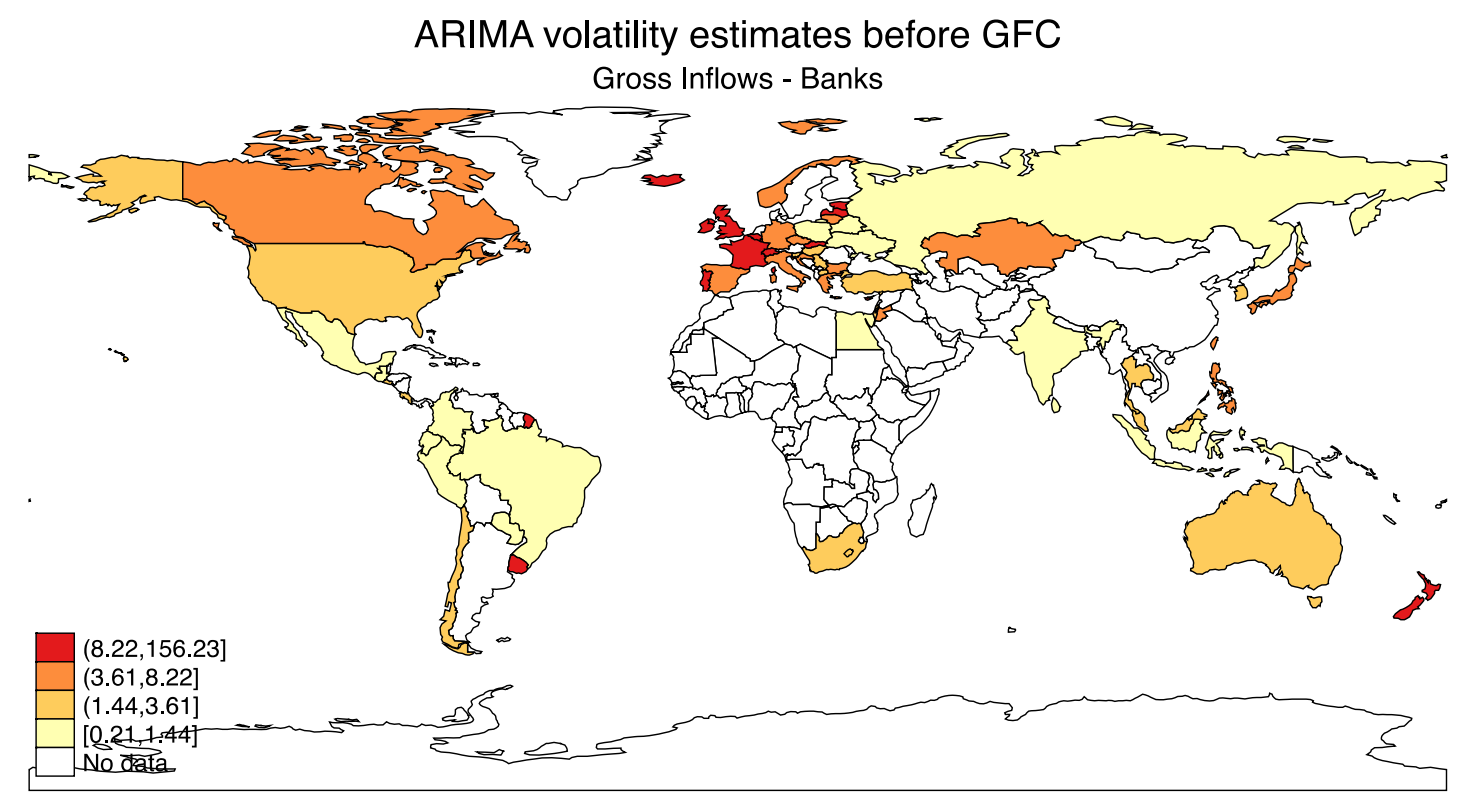

Figure 18: ARIMA volatility estimates for bank gross inflows by country over the period 2000Q12007Q2. Source: IMF, International Financial Statistics, authors' computations.

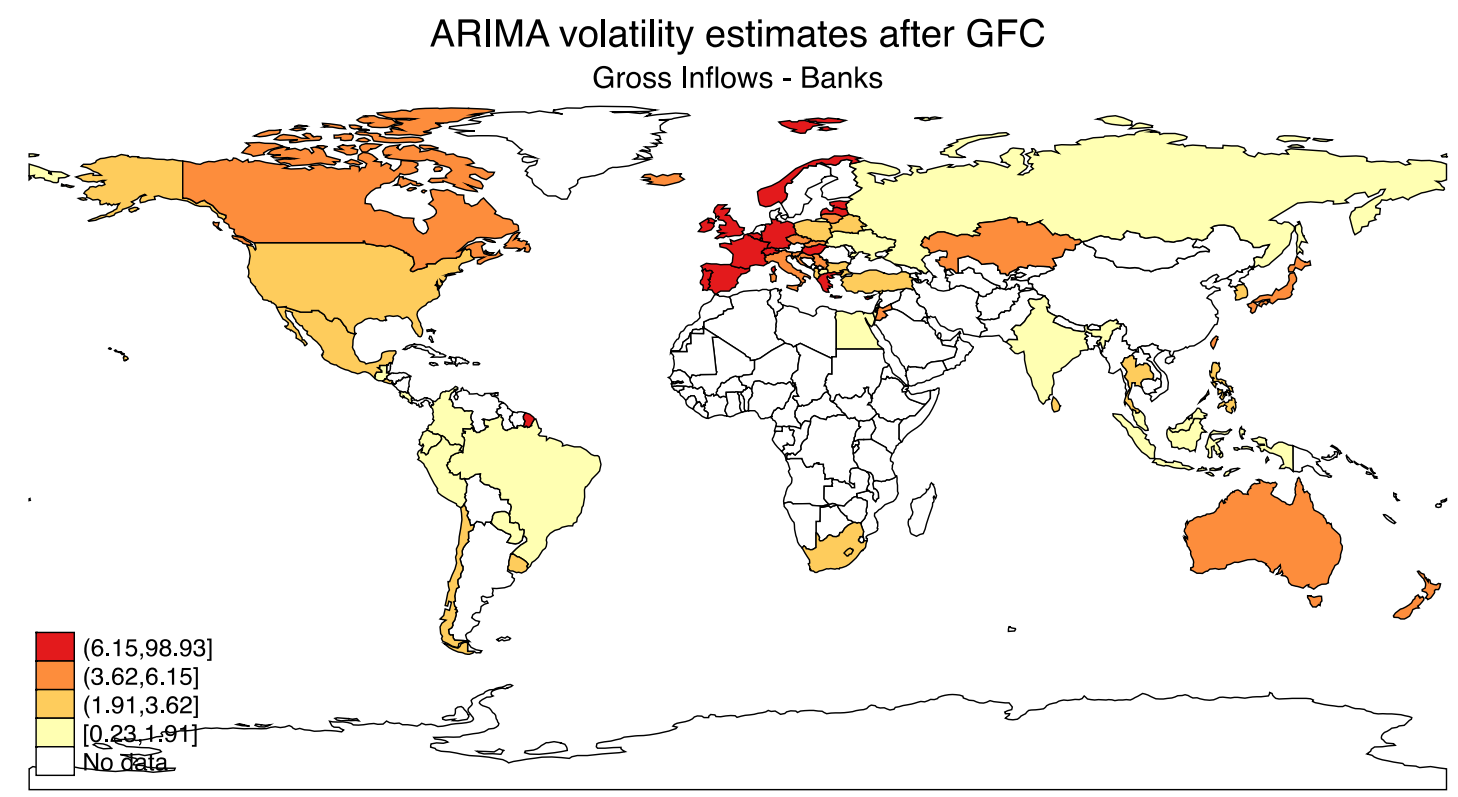

Figure 19: ARIMA volatility estimates for bank gross inflows by country over the period 2009Q32016Q1. Notes: data not available for China and Saudi Arabia. Source: IMF, International Financial Statistics, authors' computations. 
A closer look at the subcomponents of other investment inflows reveals that flows to the banking sector are the major drivers of the general trends observed above. The comparison between the two periods highlights how the peripheral Euro Area sovereign debt crisis has exacerbated the volatility of bank flows towards the Western European economies.

\section{Box 1: Do more financially developed countries have more volatile capital flows?}

We here provide an example of how to make use of our volatility estimates to address some policyrelated questions. Notably, we want to study the relationship between the volatility of capital flows and the degree of development of a country's financial system, as measured by the Financial Development Index. $^{21}$

Figure 1.1 plots the volatility of capital flows by instrument vis-à-vis the value of the Financial Development Index for each country. In some cases, the correlation is almost 0 (e.g. FDI, portfolio and other investments), whereas it is far more relevant and positive for portfolio equity. It is also interesting to notice how the GFC has led to an increase in the significance of these correlations (higher $R^{2}$ ) for all the instruments, except for portfolio equity. In addition, in the case of portfolio flows, especially portfolio debt, the sign of the correlation has switched from negative to positive during the GFC and, afterwards, it has moved back to negative.

Generally speaking, the idea that a country with a more developed financial system is subject to more volatile capital flows ${ }^{22}$ and, hence, uncertainty, is not confirmed by our simple exercise, with the exception of portfolio equity flows (whose size in the financial account of EMDEs, however, is much reduced compared to other instruments). This finding is in line with existing literature (see Bekaert and Harvey 1997, Lagoarde-Segot 2009, and Umutlu et al. 2010).

Another argument that has been debated is whether EMDEs with stronger financial systems are more prone to contagion on the part of AEs. In this regard, we perform a simple exercise, where a measure of possible contagion is provided by the correlation between our volatility estimates for EMDEs and the same estimates for AEs, across different instruments. We find that a higher and more significant degree of correlation exists between volatilities of other investments and this correlation is stronger the more financially developed is a country. As an example, the scatter plot in Figure 1.2 displays correlations between other investments volatility in EMDEs and AEs versus the Financial Development Index. It can be concluded that more financially developed economies present a higher degree of exposure towards the developments on the international financial markets.

\footnotetext{
21 The higher the value of the index, the more financially developed is a country (see Svirydzenka (2016)). Basically, the overall index of financial development is the result of the aggregation of nine sub-indices that summarize how developed financial institutions and financial markets are in terms of their depth, access, and efficiency in a particular country.

${ }^{22}$ See, for instance, Neumann et al. (2009) and Broner and Ventura (2016).
} 


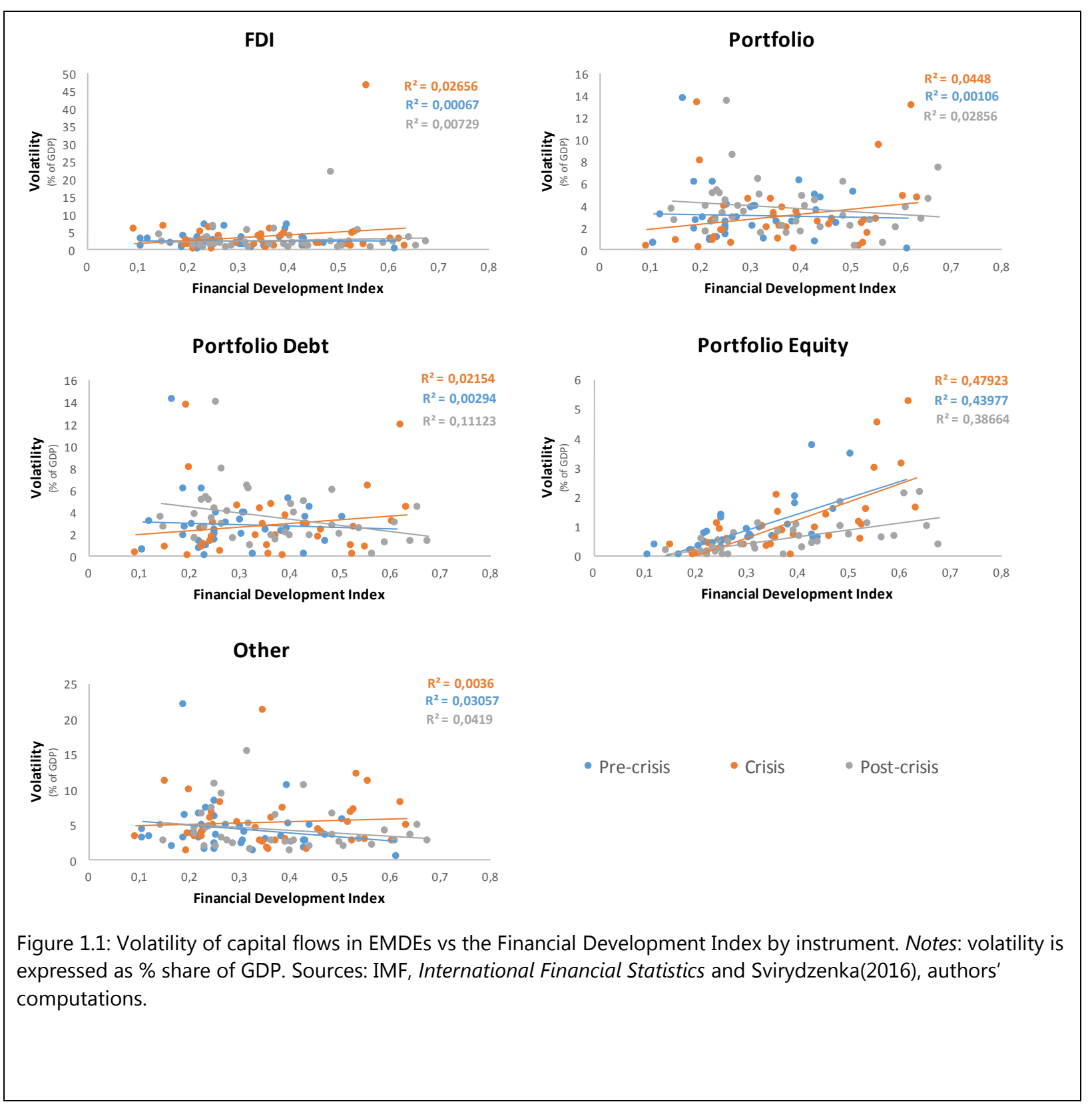




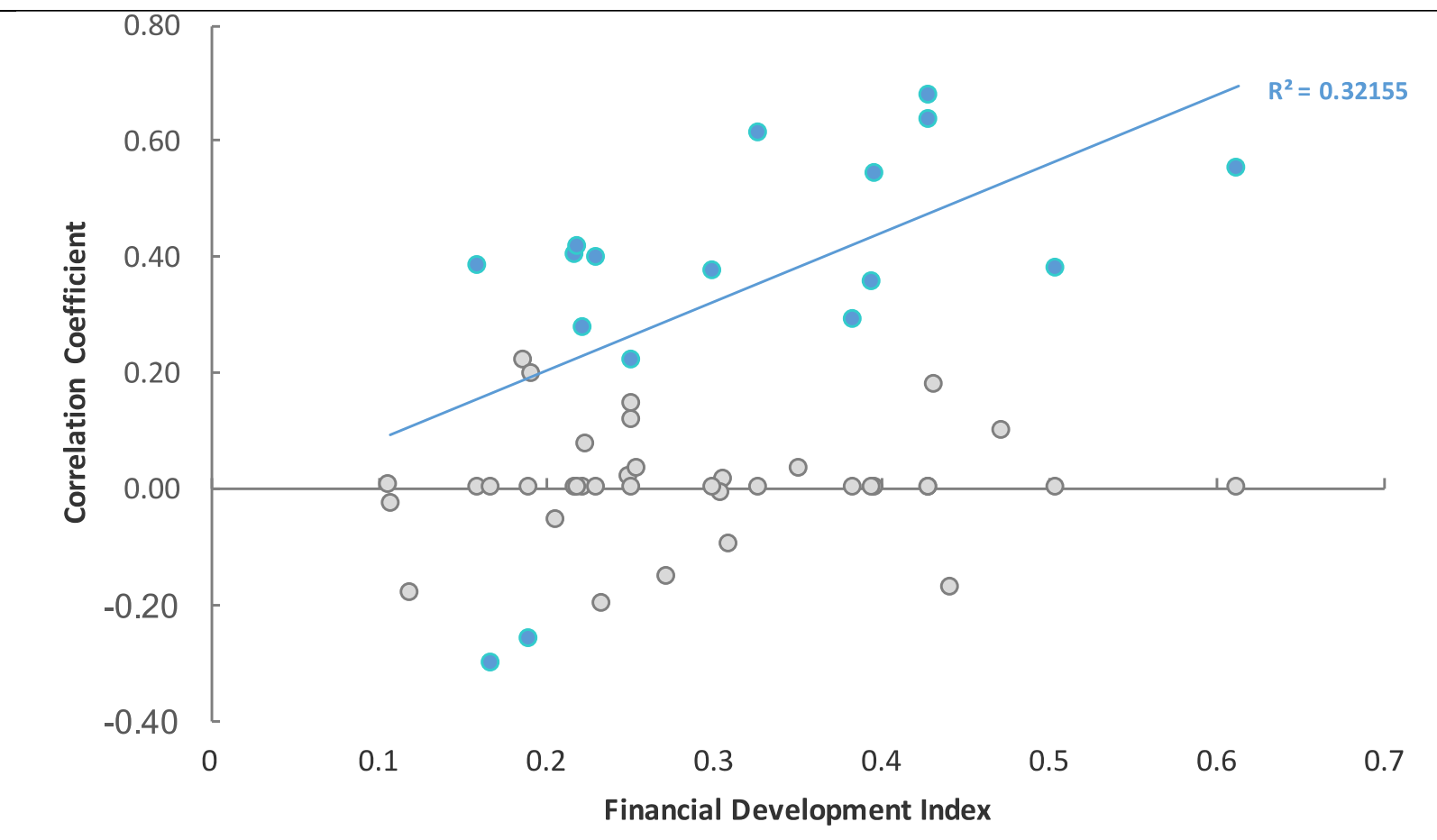

Figure 1.2: correlation coefficients between volatility estimates in EMDEs and volatility estimates in AEs vs the Financial Development Index. Notes: estimates for other inflows. Grey dots indicate non-significant estimates. The correlation coefficient is computed between the volatility for each single emerging economy in the sample and the aggregate volatility of the AEs group. Source: IMF, International Financial Statistics, authors' computations. 


\section{Explaining Volatility - PAnel Regressions}

\section{A. Regression framework}

To understand the determinants of the volatility of gross inflows in EMDEs over the period 1980Q1-2016Q1, we construct some panel regressions, where the dependent variables are the ARIMA volatility estimates for both total flows and different types of instruments. The independent variables comprise a large set of regressors grouped in three categories: 1) global factors, 2) domestic macroeconomic factors, and 3) domestic structural factors. The global variables include the US shadow rate ${ }^{23}$, the US real GDP growth, S\&P 500 volatility as a proxy of global risk aversion ${ }^{24}$, the US inflation and the log price of oil. The domestic macroeconomic variables include real GDP growth, domestic policy rate, and per capita income to capture the level of economic development. The domestic structural variables comprise capital account openness as measured by the Chin-Ito index, trade openness and reserves as a share of GDP. ${ }^{25}$ Moreover, the set of independent variables include also a dummy for the period 2007Q3-2009Q2 (GFC) and a dummy for the period 2009Q3-2016Q1.

Our approach is very similar to the previous work by Broto et al. (2011). Notably, the regression framework includes country fixed effects ${ }^{26}$, while the explanatory variables on the right-hand side are lagged by one quarter, in order to minimize possible endogeneity issues. Moreover, we correct the covariance matrix as suggested by Driscoll and Kraay (1998), to account for both serial and spatial (cross-sectional) correlations. ${ }^{27}$

\section{B. Results}

Table 4 reports the estimation outcomes using different instruments of capital flows as dependent variable. The results suggest that global factors like risk aversion, the US growth and shadow rate are important drivers of capital flow volatility. As expected, an increase in global risk aversion will also increase EMDEs capital flow volatility, and this impact seems to be statistically significant across most of the instruments. For example, one percentage point increase in global risk aversion is associated with an increase by $0.85 \%$ of GDP in the volatility of total flows to EMDEs. On the other hand, the US growth negatively affects EMDEs capital flow volatility and this is in line with the common belief that, in general and all else equal, an increase in US growth

\footnotetext{
${ }^{23}$ The use of the shadow rate instead of the policy rate (Fed Fund rate) is preferred as it allows to capture changes in US monetary policy even when the official rate is at the ZLB. Following the literature, we consider short-term interest rates as the only relevant factors. As a robustness check, we also ran regressions with long-term interest rates, but they turned out not to be significant. In our framework, indicators of US monetary policy and economic performance are used as proxies for the world economy's stance (see also Broto et al. (2011)).

${ }^{24}$ Ideally, VIX should be used. However, the series for VIX is available only from 1990 onwards. Following Ghosh et al. (2012), we use the S\&P 500 realized returns' volatility instead.

${ }^{25}$ See Appendix B for a complete list of variables.

${ }^{26}$ There is no statistical evidence of the presence of time fixed effects in this case.

${ }^{27}$ We also report clustered standard errors.
} 
implies greater stability in the global financial system. This impact is significant for all the instruments considered, with the exception of portfolio flows.

Another important global factor that influences volatility of different components of capital flows is given by commodity prices as proxied by the oil price. An increase in the price of oil, for instance, decreases the volatility of portfolio equity and other flows through the official sector, while it increases the volatility of flows through the banking sector. Notably, an increase in the oil price by $1 \%$ lowers the volatility of portfolio equity and other investments through the official sector by $0.9 \%$ and $2.85 \%$ of GDP respectively, while it increases the volatility of other investments through the banking sector by $1.34 \%$ of GDP. ${ }^{28}$ These results are basically driven by oil-exporters. A positive oil shock, indeed, increases bank investments to these countries, whose financial institutions, in turn, reinvest their increased revenues into the international financial markets, to diversify their portfolios. ${ }^{29}$ Nonetheless, changes in oil prices are also positively correlated with capital inflows to commodity importers. This could be associated with the fact that oil prices partly reflect global demand conditions and therefore global income (see Box 2$)^{30}$.

Table 4 also shows that domestic factors can be important drivers of capital flow volatility. An increase in domestic growth can decrease capital flow volatility by attracting more stable flows, and this impact is present in other investment flows and portfolio debt flows. While cyclical growth is not important for FDI volatility, in this case income per capita matters. This suggests that longer term structural factors have a more determinant impact over the stability of FDI flows. Trade openness is also an important driver of volatility across all the instruments, with more open economies, as expected, facing more volatile capital flows.

In addition, the volatility of total gross inflows, portfolio equity inflows and other investments through both the official sector and private non-banking sector were significantly higher during the GFC (by $1.47 \%, 0.39 \%, 0.94 \%$ and $0.52 \%$ of GDP respectively), while there is no such evidence for other instruments.

Table 4 suggests a confluence of global and domestic factors influence over the volatility of capital flows to EMDEs. In order to get a sense of the magnitude of each variable's impact, we compute the contribution of the most relevant factors to total capital inflows volatility, by multiplying the estimated coefficients by the corresponding indicator. ${ }^{31}$ Results are pictured in Figure 20. Among the global factors, the risk index is contributing the most to volatility, whereas the impact of the US shadow rate is more relevant before GFC. After the US policy rate hit the zero lower bound, the contribution of the shadow rate has become small, while the negative impact of US growth is more consistent over time, except for the period between 2009 and 2010, when it has turned positive. Among the domestic factors, trade openness is playing a major role in driving volatility, with more open economies experiencing higher volatility as expected. The income per capita is

\footnotetext{
${ }^{28}$ Note that the specification of the regression framework is such that the coefficient for the log oil price on the righthand side represents the semi-elasticity of capital flow volatility to oil price.

${ }^{29}$ See Arezki, Mazarei, and Prasad (2015) and Arezki, Obstfeld and Milesi-Ferretti (2016).

${ }^{30}$ See Ahmed, Curcuru and Warnock (2015).

${ }^{31}$ For the domestic variables, the actual values represent the average of the values across countries for each quarter.
} 
also important, with richer economies exhibiting greater volatility ceteris paribus. Interestingly, the contribution of real GDP growth is usually close to zero from below (even more so after the crisis), with an isolated positive spike at the end of the GFC.

Our results provide interesting information as to the role of push versus pull factors in influencing capital flow developments. Recent studies, e.g. IMF (2016), have found that the real GDP growth differentials vis-à-vis advanced economies play an important role in determining capital flow movements. IMF (2016, Figure 2.17) also shows that the positive contribution towards capital flows (in level terms) from growth differential is higher than the negative contribution from global risk aversion. Our results suggest that the determinants of capital flow volatility can be quite different from the determinants of their levels. For instance, we find that a global factor like risk aversion can be more important than domestic macroeconomic variables like GDP growth in driving volatility.

As a robustness check, we include several interaction terms between the crisis and post-crisis dummies and some regressors. While there are some differences, there is no change in the main takeaways of our econometric analysis.

We caution, however, that the $\mathrm{R}^{2}$ is not very high for any of the instruments (the maximum being 0.176). While this is normal for regressions whose dependent variables are measures of volatility, it also implies that there are other relevant factors beyond the ones considered by the literature, whose identification provides an interesting direction for future research.

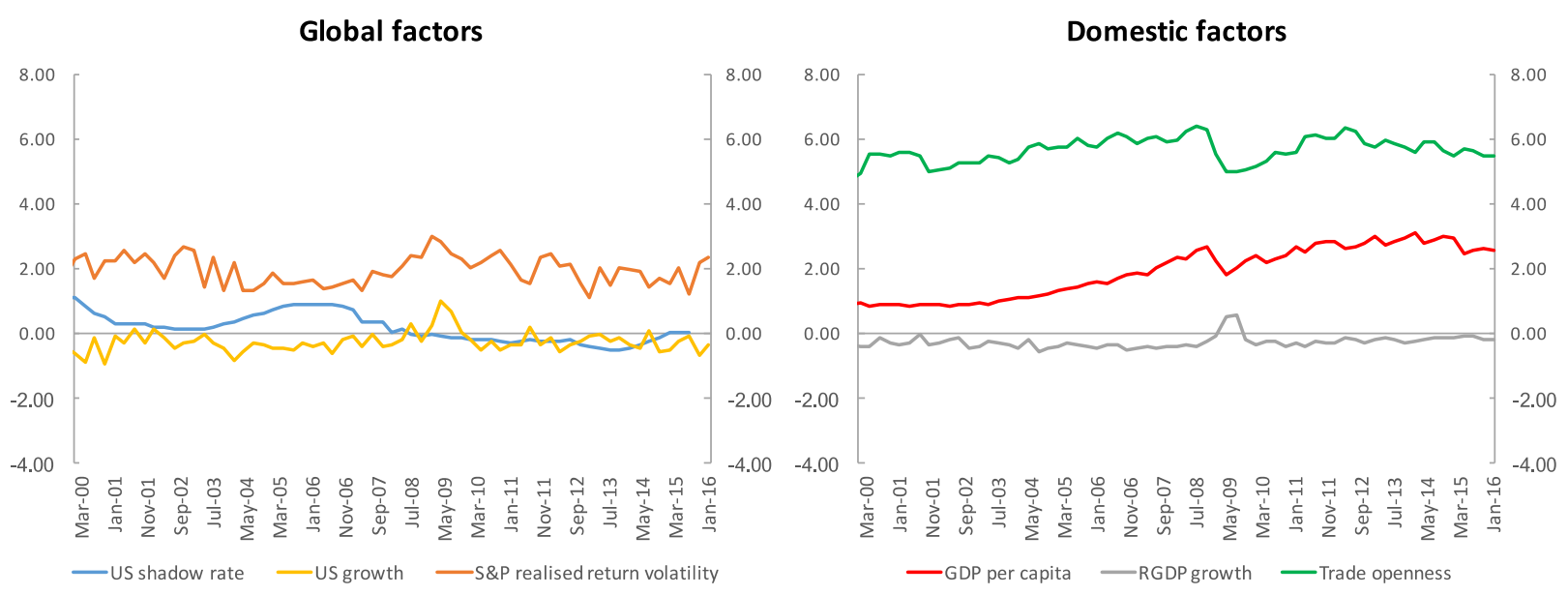

Figure 20: Factor contributions to the volatility of total gross inflows in EMDEs. Notes: Contributions are computed as an average of each factor's contributions across countries. Source: IMF, International Financial Statistics, authors' computations. 


\begin{tabular}{|c|c|c|c|c|c|c|c|c|c|c|}
\hline VARIABLES & $\begin{array}{c}\text { (1) } \\
\text { Total }\end{array}$ & $\begin{array}{l}\text { (2) } \\
\text { FDI }\end{array}$ & $\begin{array}{c}\text { (3) } \\
\text { Portfolio }\end{array}$ & $\begin{array}{c}\text { (4) } \\
\text { Portfolio } \\
\text { Debt }\end{array}$ & $\begin{array}{l}\text { (5) } \\
\text { Portfolio } \\
\text { Equity }\end{array}$ & $\begin{array}{c}\text { (6) } \\
\text { Other }\end{array}$ & $\begin{array}{c}\text { (7) } \\
\text { Banks }\end{array}$ & $\begin{array}{c}\text { (8) } \\
\text { Official }\end{array}$ & $\begin{array}{c}\text { (9) } \\
\text { Non-banks }\end{array}$ & $\begin{array}{c}\text { (10) } \\
\text { Total } \\
\text { private }\end{array}$ \\
\hline \multirow[t]{3}{*}{ US shadow rate $(\mathrm{t}-1)$} & $0.174 * *$ & $0.170 * *$ & $0.0854 * *$ & 0.0192 & $0.0909 * * *$ & $0.114^{*}$ & $0.145^{* *}$ & 0.0436 & 0.0551 & $0.116 * * *$ \\
\hline & [0.0948] & {$[0.0772]$} & [0.0813] & [0.0694] & [0.0385] & {$[0.0780]$} & [0.0739] & [0.0568] & [0.0429] & [0.0552] \\
\hline & $(0.0714)$ & $(0.0665)$ & $(0.0358)$ & $(0.0426)$ & $(0.0233)$ & $(0.0663)$ & $(0.0555)$ & $(0.0461)$ & $(0.0350)$ & $(0.0435)$ \\
\hline \multirow[t]{3}{*}{ S\&P 500 returns volatility (t-1) } & $0.849 * * *$ & $0.526 * * *$ & $0.225 * *$ & $0.222 * *$ & 0.00865 & $0.331 *$ & 0.282 & 0.235 & $0.198 * * *$ & $0.375^{* * *}$ \\
\hline & [0.383] & [0.359] & [0.148] & {$[0.125]$} & [0.0586] & [0.148] & [0.142] & [0.132] & [0.0901] & [0.134] \\
\hline & $(0.191)$ & $(0.141)$ & (0.101) & (0.0939) & $(0.0481)$ & $(0.192)$ & $(0.171)$ & $(0.173)$ & $(0.0572)$ & $(0.136)$ \\
\hline \multirow[t]{3}{*}{ US growth(t-1) } & $-0.492 * * *$ & $-0.444 * * *$ & 0.0272 & 0.0484 & -0.0538 & $-0.444 * * *$ & $-0.216 * * *$ & -0.169 & $-0.108 *$ & $-0.264 * * *$ \\
\hline & [0.305] & [0.287] & [0.116] & [0.0948] & [0.0389] & [0.131] & {$[0.140]$} & [0.0953] & [0.0577] & [0.109] \\
\hline & $(0.136)$ & $(0.105)$ & $(0.0546)$ & (0.0459) & $(0.0443)$ & $(0.121)$ & $(0.0787)$ & $(0.107)$ & (0.0548) & $(0.0904)$ \\
\hline \multirow[t]{3}{*}{ US inflation $(\mathrm{t}-1)$} & $-0.320 * *$ & -0.0465 & 0.0688 & -0.00891 & 0.0254 & $-0.244^{*}$ & $-0.132 * *$ & 0.0642 & -0.0261 & $-0.197 * * *$ \\
\hline & {$[0.151]$} & {$[0.0691]$} & [0.0960] & [0.0638] & [0.0418] & [0.107] & {$[0.0780]$} & [0.0708] & [0.0512] & [0.101] \\
\hline & $(0.126)$ & $(0.0841)$ & $(0.0593)$ & $(0.0357)$ & $(0.0384)$ & $(0.125)$ & $(0.0502)$ & $(0.0527)$ & $(0.0434)$ & $(0.0720)$ \\
\hline \multirow[t]{3}{*}{ Oil price $(\log )_{(t-1)}$} & 1.224 & -0.484 & $-1.329 * *$ & -0.934 & $-0.896 * *$ & 0.0114 & $1.335 * *$ & $-2.848 * * *$ & 0.130 & 0.988 \\
\hline & [1.732] & [1.306] & {$[0.844]$} & [0.792] & {$[0.651]$} & [0.979] & [0.602] & [1.097] & [1.010] & [0.898] \\
\hline & $(1.112)$ & (1.059) & $(0.643)$ & $(0.591)$ & $(0.348)$ & $(0.887)$ & $(0.607)$ & $(0.543)$ & $(0.403)$ & $(0.606)$ \\
\hline \multirow[t]{3}{*}{ RGDP growth(t-1) } & $-0.230 * * *$ & $-0.0689 * *$ & $-0.0387 * *$ & -0.0387 & 0.00100 & $-0.125^{* * *}$ & -0.0186 & $-0.0687 * *$ & $-0.0345^{* *}$ & $-0.0772 * *$ \\
\hline & {$[0.100]$} & {$[0.0621]$} & {$[0.0216]$} & [0.0229] & [0.0110] & [0.0693] & {$[0.0388]$} & {$[0.0536]$} & {$[0.0190]$} & [0.0419] \\
\hline & $(0.0450)$ & $(0.0342)$ & $(0.0192)$ & $(0.0251)$ & $(0.0140)$ & $(0.0424)$ & $(0.0289)$ & $(0.0263)$ & $(0.0153)$ & $(0.0325)$ \\
\hline \multirow[t]{3}{*}{ GDP per capita(t-1) } & $0.00130 * *$ & $0.00148 * * *$ & $0.000568 * * *$ & $0.000363^{* *}$ & $0.000144^{*}$ & $0.000747 * *$ & 0.000732 & $0.00101 * * *$ & -0.000168 & $6.07 e-06$ \\
\hline & {$[0.00121]$} & {$[0.00140]$} & [0.000333] & {$[0.000314]$} & [0.000143] & {$[0.000680]$} & [0.000428] & {$[0.000712]$} & {$[0.000350]$} & [0.000390] \\
\hline & $(0.000524)$ & $(0.000502)$ & $(0.000201)$ & $(0.000165)$ & $(7.52 \mathrm{e}-05)$ & $(0.000305)$ & $(0.000440)$ & $(0.000255)$ & $(0.000141)$ & $(0.000320)$ \\
\hline \multirow[t]{3}{*}{ Policy rate(t-1) } & 0.0177 & -0.00488 & 0.00362 & -0.00504 & 0.00126 & $0.0240 *$ & $0.0273 * * *$ & 0.00154 & 0.00381 & 0.000520 \\
\hline & {$[0.0216]$} & {$[0.0301]$} & {$[0.0121]$} & [0.0110] & [0.00608] & [0.0204] & {$[0.0128]$} & [0.0278] & [0.0169] & [0.0109] \\
\hline & $(0.0197)$ & $(0.0245)$ & $(0.0116)$ & $(0.00974)$ & $(0.00432)$ & $(0.0142)$ & (0.00989) & $(0.00980)$ & $(0.00854)$ & $(0.00881)$ \\
\hline \multirow[t]{3}{*}{ Chinn-Ito index(t-1) } & $-2.029 *$ & -1.105 & 0.338 & 0.205 & $0.601 * * *$ & -0.578 & $1.453 * *$ & $-1.376 * *$ & $-0.651 * *$ & -0.183 \\
\hline & [1.494] & [2.341] & [0.564] & [0.560] & [0.307] & [0.977] & [1.066] & [1.362] & [0.640] & {$[0.560]$} \\
\hline & $(1.020)$ & $(0.986)$ & $(0.526)$ & $(0.482)$ & $(0.160)$ & $(0.590)$ & $(0.608)$ & $(0.611)$ & $(0.303)$ & $(0.424)$ \\
\hline \multirow[t]{3}{*}{ Trade openness(t-1) } & $0.0845 * * *$ & $0.0684 * * *$ & $0.0320 * * *$ & $0.0273 * * *$ & $0.0180 * * *$ & 0.0227 & 0.0127 & $0.0300 * * *$ & $0.0212 * * *$ & $0.0195^{* *}$ \\
\hline & {$[0.0361]$} & [0.0469] & [0.0113] & [0.0124] & {$[0.00721]$} & [0.0124] & [0.0125] & {$[0.0126]$} & [0.00930] & [0.00979] \\
\hline & $(0.0192)$ & $(0.0219)$ & (0.00709) & $(0.00524)$ & $(0.00406)$ & $(0.0152)$ & $(0.0100)$ & $(0.0101)$ & $(0.00566)$ & $(0.00820)$ \\
\hline \multirow[t]{3}{*}{ Reserves/GDP $(\mathrm{t}-1)$} & 0.00708 & 0.0157 & $0.00500 *$ & $0.00593 * *$ & $0.00703 * * *$ & 0.00406 & $0.0310 * * *$ & -0.000519 & $-0.00701^{*}$ & $0.00920 * * *$ \\
\hline & [0.0119] & [0.0112] & {$[0.00365]$} & [0.00445] & {$[0.00346]$} & {$[0.00742]$} & [0.01000] & [0.0109] & [0.00870] & {$[0.00729]$} \\
\hline & $(0.0124)$ & $(0.0101)$ & $(0.00265)$ & $(0.00297)$ & $(0.00208)$ & $(0.00478)$ & $(0.00561)$ & $(0.00890)$ & $(0.00410)$ & (0.00319) \\
\hline \multirow[t]{3}{*}{ Crisis } & $1.467 * *$ & 0.346 & -0.0601 & -0.0655 & $0.382 * *$ & 0.624 & -0.356 & $0.938 * * *$ & $0.515 * *$ & 0.146 \\
\hline & {$[0.726]$} & [0.653] & [0.382] & [0.478] & [0.315] & [0.483] & [0.311] & {$[0.470]$} & [0.504] & {$[0.361]$} \\
\hline & $(0.664)$ & $(0.531)$ & (0.209) & $(0.240)$ & $(0.166)$ & $(0.538)$ & (0.391) & $(0.314)$ & $(0.244)$ & $(0.384)$ \\
\hline
\end{tabular}




\begin{tabular}{|c|c|c|c|c|c|c|c|c|c|c|}
\hline \multirow[t]{3}{*}{ Post-crisis } & -0.979 & -0.888 & 0.437 & 0.170 & 0.0329 & -0.168 & $-1.024^{*}$ & 0.765 & 0.135 & -0.149 \\
\hline & [0.964] & [1.080] & [0.383] & [0.351] & [0.313] & [0.977] & [0.473] & [0.585] & [0.717] & [0.493] \\
\hline & $(0.786)$ & $(0.669)$ & $(0.274)$ & $(0.328)$ & $(0.208)$ & $(0.731)$ & $(0.562)$ & $(0.474)$ & (0.319) & $(0.424)$ \\
\hline \multirow[t]{2}{*}{ Constant } & $-4.135^{* *}$ & $-4.594 * * *$ & 1.153 & 1.084 & 0.0707 & 0.850 & $-4.654 * * *$ & $3.844 * * *$ & $1.033^{*}$ & -0.804 \\
\hline & $(1.653)$ & $(1.443)$ & $(0.722)$ & $(0.702)$ & $(0.478)$ & (1.019) & $(1.190)$ & $(1.097)$ & $(0.606)$ & $(0.886)$ \\
\hline Observations & 1,405 & 1,405 & 1,409 & 1,369 & 1,386 & 1,410 & 1,298 & 1,332 & 1,322 & 1,405 \\
\hline Within $\mathrm{R}^{2}$ & 0.176 & 0.116 & 0.0732 & 0.0666 & 0.149 & 0.112 & 0.184 & 0.130 & 0.0882 & 0.0834 \\
\hline
\end{tabular}

Table 4: Baseline regression for volatility of capital inflows. Notes: Clustered standard errors in brackets, Driscoll and Kraay (DK) standard errors in parentheses. $* * * \mathrm{p}<0.01, * * \mathrm{p}<0.05, * \mathrm{p}<0.1$, using Driscoll and Kraay standard errors. Some countries have been excluded from the pool due to lack of an adequate number of observations. 


\section{Box 2: The volatility of bank flows versus oil price}

The results provided by the panel regressions allow us to study a bit more in-depth the relationship between capital flow volatility and some factors that are deemed influential by the literature. In particular, here we focus on the effect of a change in the price of oil over the volatility of bank inflows. This is relevant in light of some empirical work that underlines the crucial link existing between banks' profitability and, hence, the soundness of the banking system and oil price, a link that operates mainly through macroeconomic channels and is particularly strong in oil-exporting emerging economies. ${ }^{32} \mathrm{As}$ we used the log of oil price in the right-hand side of the regression, it is possible to estimate the elasticity of volatility to oil price.

Figure 2.1 displays the evolution of elasticity over time, by disentangling between oil exporting and oil importing economies. The elasticity has gradually decreased over time, until the aftermath of the GFC. In the pre-crisis period, indeed, the overall average elasticity is $1.26 \%$ (i.e. a $1 \%$ increase in the oil price leads to a $1.26 \%$ increase in bank inflows volatility), while the same average decreases to $0.95 \%$ after the GFC. In addition, it seems that, on average, elasticity in oil exporting economies has increased after the crisis, compared to earlier periods, a trend which is opposite to what observed for oil importers.

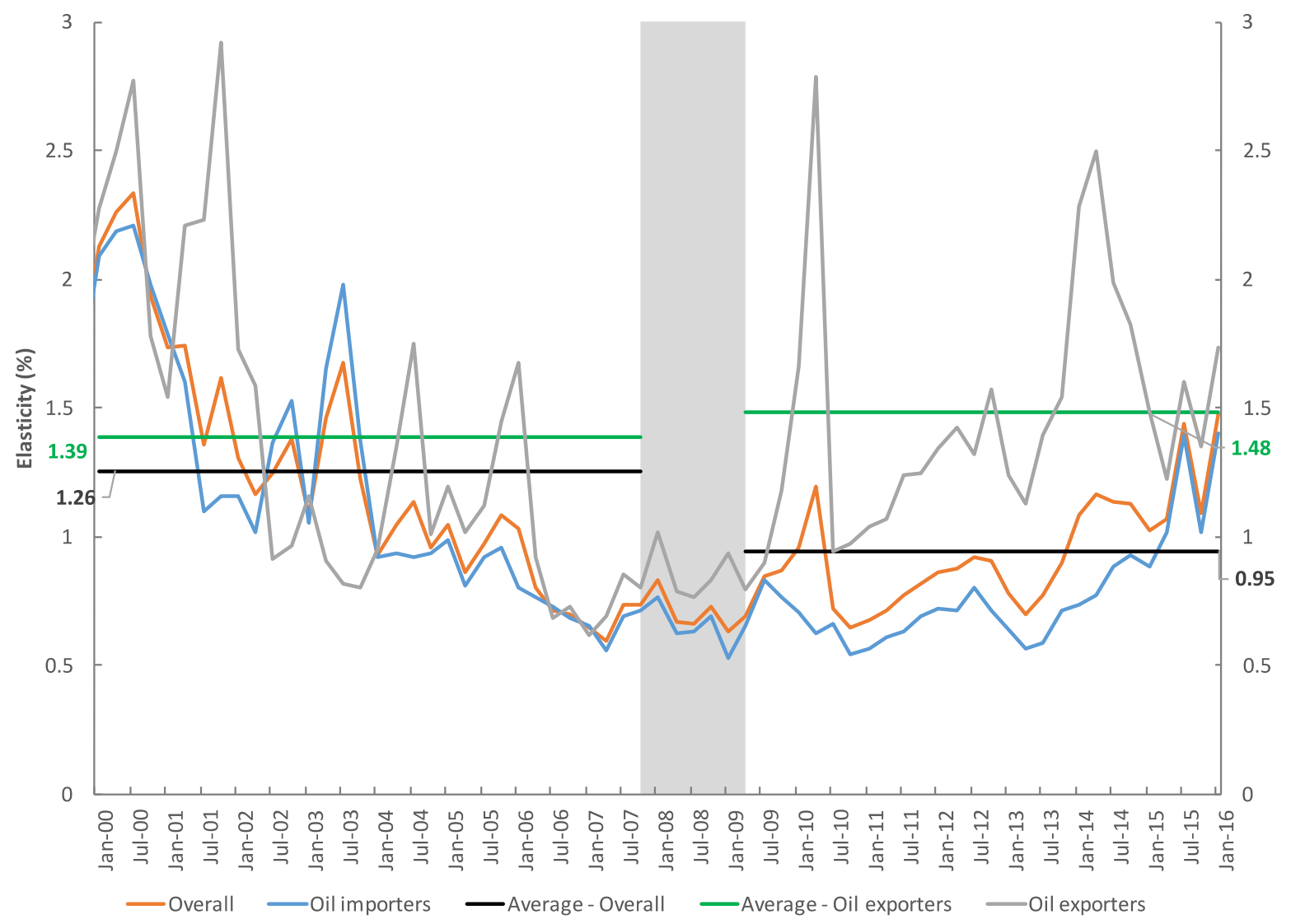

Figure 2.1: Average elasticity of gross bank inflows volatility to oil price in EMDEs. Notes: the shaded area indicates the GFC period. Oil exporters in the sample are: Brazil, Ecuador, Egypt, Indonesia, Kazakhstan, Mexico, Malaysia, Russia and Saudi Arabia. Source: IMF, International Financial Statistics, authors' computations.

${ }^{32}$ See, for instance, Hesse and Poghosyan (2009). 
Figure 2.2 depicts the evolution in the median elasticities for the overall sample, oil exporters and oil importers. The picture provided is more interesting, as it looks like that, during periods of financial distress (GFC), the median values all collapse to around the same level, both for oil exporters and importers. This suggests that the distributions of oil price elasticities across groups tend to coincide when an aggregate shock hits, while in more "normal" times they are distinct.

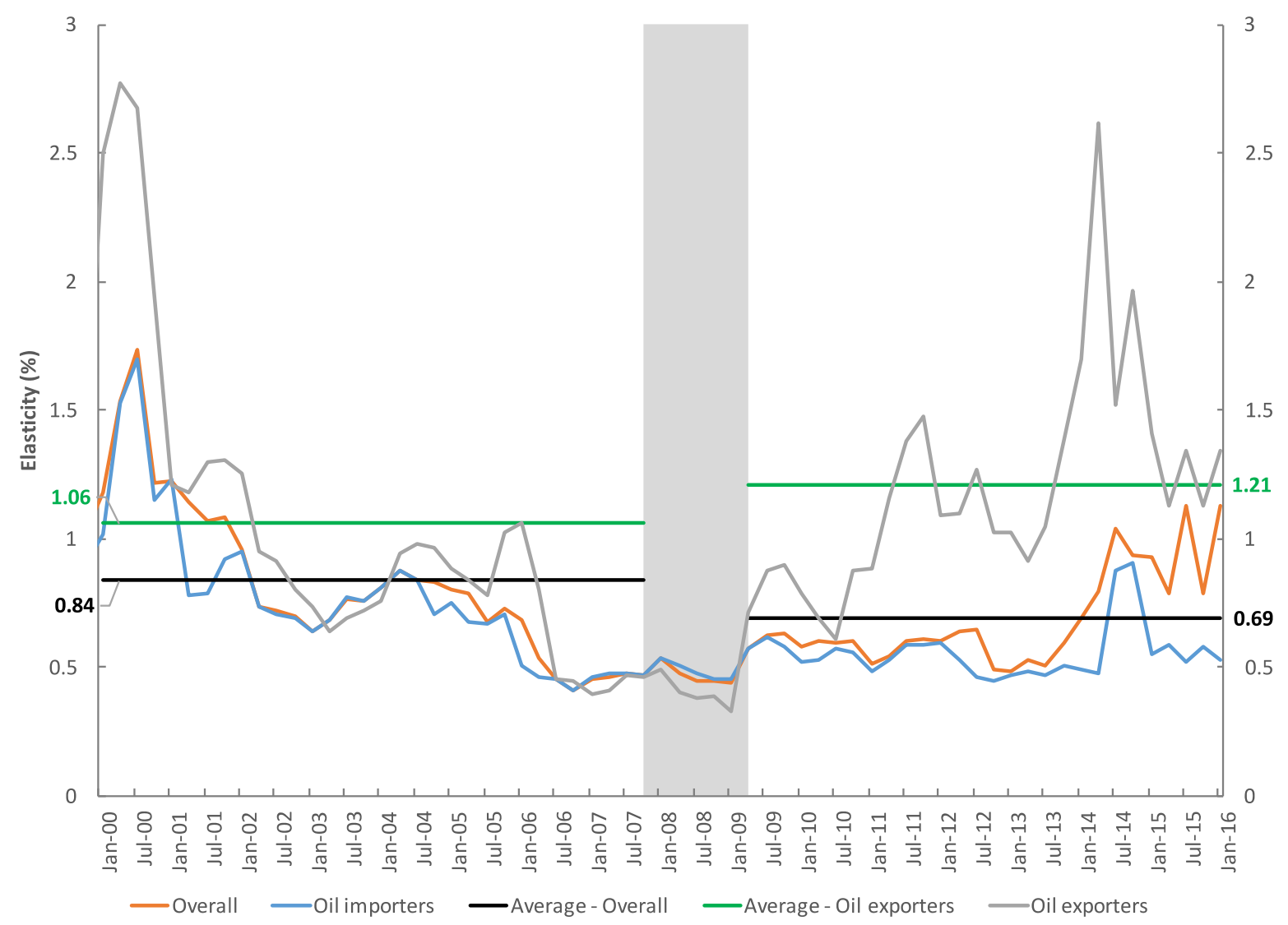

Figure 2.2: Median elasticity of gross bank inflows volatility to oil price in EMDEs. Notes: the shaded area indicates the GFC period. Oil exporters in the sample are: Brazil, Ecuador, Egypt, Indonesia, Kazakhstan, Mexico, Malaysia, Russia and Saudi Arabia. Source: IMF, International Financial Statistics, authors' computations.

Figure 2.3 displays the evolution of the median and the interquartile range of the estimates over time, for oil exporting and oil importing economies. This gives us a better sense of whether the changes observed above are driven by shifts in the overall distribution or by movements at the ends of the distribution (outliers). While for oil importers (bottom panel), we do not observe much variation in the median after mid-2000, on the other hand the interquartile range has considerably narrowed over time. This points at a change towards a distribution of elasticity which is more concentrated around the median (lower variance). For oil exporters (upper panel), conversely, it looks like there have been shifts in the entire distribution of elasticity. Notably, the median elasticity has decreased in the mid-2000s and, later, during the GFC, whereas it has started to increase again soon after the crisis, with a spike in the period 2014-2015. 


\section{Oil exporters}

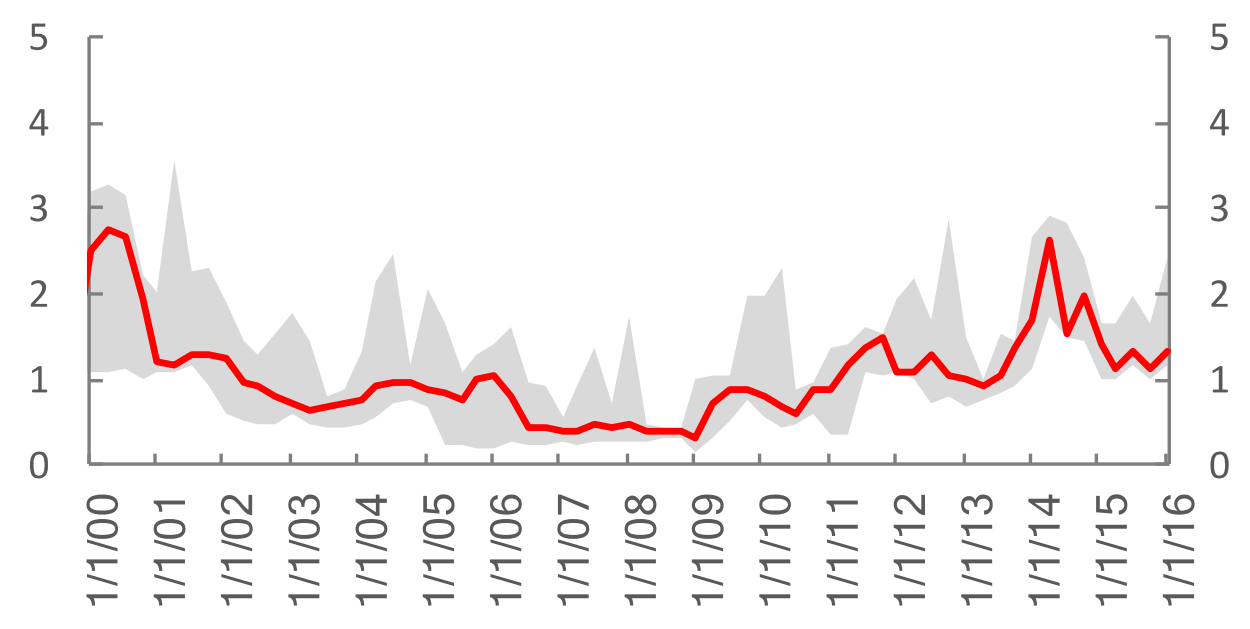

\section{Oil importers}

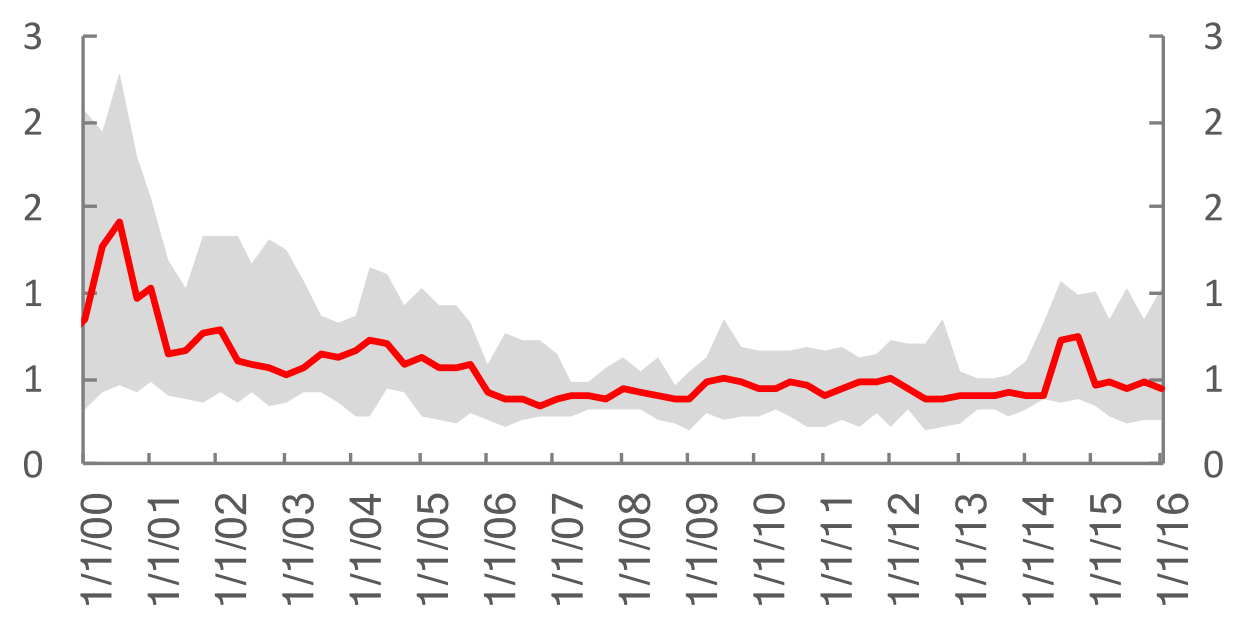

\section{Interquantile range}

-Median

Figure 2.3: Median and interquartile ranges of the elasticity of gross bank inflows volatility to oil price in EMDEs. Notes: Oil exporters in the sample are: Brazil, Ecuador, Egypt, Indonesia, Kazakhstan, Mexico, Malaysia, Russia and Saudi Arabia. Source: IMF, International Financial Statistics, authors' computations. 


\section{Concluding Thoughts}

This paper is an attempt to deepen our understanding of capital flow volatility, which is a major policy concern. To start off, we quantify volatility using three measures: rolling standard deviation, GARCH, and ARIMA estimates. We show that there is sufficient heterogeneity, both across countries and across instruments, to warrant examining these entities separately. In addition, following recent literature arguing that the pattern of net flows can be different from gross inflows and gross outflows, we look at both net and gross flows. One of the major contributions of this paper thus consists of the development of a comprehensive set of volatility estimates of capital flows, encompassing gross and net flows as well as different instruments across thirty-seven individual EMDEs and twenty-eight individual AEs.

Constructing volatility estimates for both the aggregate EMDEs and the individual countries, we document the evolution of volatility over time and compare the levels of volatility across instruments. The results of aggregate EMDEs show that portfolio debt and bank flows tend to be more volatile than FDI flows. We also find that the volatility of all instruments is prone to bouts during episodes of global financial turmoil. The results for the individual countries suggest that there can be significant variation amongst countries. The patterns witnessed in volatility of aggregate EMDE, both in terms of evolution over time and relative magnitude across instruments, do not necessarily hold across countries. These variations underscore the importance of also monitoring volatility of individual countries.

In addition, the measures we use are a way to extrapolate information about uncertainty in international capital markets. While the GFC was an episode of generalized higher uncertainty, the pre and post crisis periods display volatility patterns that are very similar to each other. That said, only a limited part of such uncertainty is attributable to domestic macroeconomic and structural factors, as well as to relevant global factors.

Our estimates for individual countries can be useful for future studies on this issue, particularly as far as cross-country analysis is concerned, since there exists a high degree of heterogeneity across countries. As an example, we use these measures to perform panel regressions with the aim of understanding the determinants of volatility. Interestingly, our results show that push factors can be relatively more important than pull factors, thus suggesting that some of the characteristics of capital flow volatility can be different from those of capital flows levels.

Future studies could aim at further informing about different aspects of capital flow volatility. In this regard, we also briefly touch upon some issues to provide motivation for further analysis on some topics. For instance, we show through simple scatterplots that the relationship between financial depth and capital flow volatility is significant only for certain instruments, whereas a higher degree of financial development increases a country's exposure on the international financial markets. This analysis could be extended by building a fully-fledged analytical framework to study the linkages between financial depth and volatility. We also show that commodity prices can influence the volatility of bank flows, an analysis which is definitively worth extending, given the recent developments in that sphere 


\section{REFERENCES}

IEO (2015), 'IEO Evaluation Report on the IMF's Approach to Capital Account Liberalization: Revisiting the 2005 IEO Evaluation', International Monetary Fund.

Aghion, P.; Bacchetta, P. \& Banerjee, A. (2004), 'Financial development and the instability of open economies', Journal of Monetary Economics 51(6), 1077--1106.

Agrippino, S. \& Rey, H. (2014), 'World Asset Markets and the Global Financial Cycle', Technical report, Technical Report, Working Paper, London Business School.

Agrippino, S. M. \& Rey, H. (2013), Funding Flows and Credit in Carry Trade Economies, in Alexandra Heath; Matthew Lilley \& Mark Manning, ed., 'Liquidity and Funding Markets', Reserve Bank of Australia.

Ahmed S.; Curcuru S. \& Warnock, F. (2015), 'Decomposing International Portfolio Flows'

Ahmed, S. (2015), 'If the Fed Acts, How Do You React? The Liftoff Effect on Capital Flows', IMF Working Paper.

Ahmed, S. \& Zlate, A. (2014), 'Capital flows to emerging market economies: A brave new world?', Journal of International Money and Finance 48(PB), 221-248.

Aizenman, J. \& Binici, M. (2016), 'Exchange market pressure in OECD and emerging economies: Domestic vs. external factors and capital flows in the old and new normal ', Journal of International Money and Finance 66, 65 - 87.

Akinci, O. \& Olmstead-Rumsey, J. (2015), 'How Effective are Macroprudential Policies? An Empirical Investigation'(1136), Technical report, Board of Governors of the Federal Reserve System (U.S.).

Alberola, E.; Erce, A. \& Serena, J. M. (2016), 'International reserves and gross capital flows dynamics ', Journal of International Money and Finance 60, 151 - 171.

Albuquerque, R. (2003), 'The composition of international capital flows: risk sharing through foreign direct investment', Journal of International Economics 61(2), 353--383.

Alfaro, L.; Kalemli-Ozcan, S. \& Volosovych, V. (2007), Capital flows in a globalized world: The role of policies and institutions'Capital Controls and Capital Flows in Emerging Economies: Policies, Practices and Consequences', University of Chicago Press, pp. 19-72.

Alonso Alvarez, I. (2015), 'Institutional drivers of capital flows', Banco de España Working Paper No. 1531, 16 November.

Arezki, R., M. Obstfeld, and G.M. Milesi-Ferretti (2016), “Oil prices and the global economy: It's complicated", VoxEU.org, 13 April. 
Arezki, R., A. Mazarei, and A. Prasad (2015), 'Sovereign wealth funds in the new era of oil', VoxEU.org, 29 November.

Bacchetta, P. \& Van Wincoop, E. (1998), 'Capital flows to emerging markets: liberalization, overshooting, and volatility', Technical report, National Bureau of Economic Research.

Beirne, J. \& Friedrich, C. (2014), 'Capital flows and macroprudential policies - A multilateral assessment of effectiveness and externalities'(1721), Technical report, European Central Bank.

Bekaert, G. \& Harvey, C. R. (1997), 'Emerging equity market volatility', Journal of Financial economics 43(1), 29--77.

Bernanke, B. S.; Boivin, J. \& Eliasz, P. (2004), 'Measuring the Effects of Monetary Policy: A Factor-Augmented Vector Autoregressive (FAVAR) Approach'(10220), Technical report, National Bureau of Economic Research.

Blanchard, O. (2016), 'Currency Wars, Coordination, and Capital Controls'(22388), Technical report, National Bureau of Economic Research.

Bluedorn, J. C.; Duttagupta, R.; Guajardo, J. \& Topalova, P. (2013), 'Capital Flows are Fickle; Anytime, Anywhere'(13/183), Technical report, International Monetary Fund.

Boivin, J. \& Giannoni, M. (2008), 'Global Forces and Monetary Policy Effectiveness'(13736), Technical report, National Bureau of Economic Research.

Bollerslev, T. (1986), 'Generalized autoregressive conditional heteroskedasticity', Journal of Econometrics 31(3), 307-327.

Broner, F. \& Ventura, J. (2016), 'Rethinking the Effects of Financial Globalization', The Quarterly Journal of Economics 131(3), 1497-1542.

Broto, C.; Díaz-Cassou, J. \& Erce, A. (2011), 'Measuring and explaining the volatility of capital flows to emerging countries', Journal of Banking \& Finance 35(8), 1941-1953.

Bruno, V. \& Shin, H. S. (2013), 'Capital Flows, Cross-Border Banking and Global Liquidity'(19038), Technical report, National Bureau of Economic Research.

Bruno, V. \& Shin, H. S. (2013), 'Capital Flows and the Risk-Taking Channel of Monetary Policy'(18942), Technical report, National Bureau of Economic Research.

Canuto, O. \& Ghosh, S. (2013), 'Dealing with the Challenges of Macro Financial Linkages in Emerging Markets', World Bank - Economic Premise (129), 1-8.

Cerutti, E.; Claessens, S. \& Laeven, L. (2015), 'The Use and Effectiveness of Macroprudential Policies; New Evidence'(15/61), Technical report, International Monetary Fund. 
Chen, J.; Mancini Griffoli, T. \& Sahay, R. (2014), 'Spillovers from United States monetary policy on emerging markets: different this time?' .

Chinn, M. \& Ito, H. (2006), 'What matters for financial development? Capital controls, institutions, and interactions', Journal of Development Economics 81(1), 163-192.

Chuang, C.-C.; Kuan, C.-M. \& Lin, H.-y. (2009), 'Causality in quantiles and dynamic stock return-volume relations', Journal of Banking \& Finance 33(7), 1351--1360.

Correa, R.; Paligorova, T.; Sapriza, H. \& Zlate, A. (2016), 'Cross-Border Bank Flows and Monetary Policy', forthcoming.

Crucini, M. J.; Kose, M. A. \& Otrok, C. (2008), 'What Are the Driving Forces of International Business Cycles?'(14380), Technical report, National Bureau of Economic Research.

Dell'Erba, S. \& Reinhardt, D. (2015), 'FDI, debt and capital controls', Journal of International Money and Finance 58(C), 29-50.

Driscoll, J. C. \& Kraay, A. C. (1998), 'Consistent covariance matrix estimation with spatially dependent panel data', Review of economics and statistics 80(4), 549--560.

Easterly, W.; Islam, R. \& Stiglitz, J. E. (2001), 'Shaken and Stirred: Explaining Growth Volatility', The World Bank Washington, DC, 191.

Eichengreen, B. (2001), 'Capital Account Liberalization: What Do Cross-Country Studies Tell Us?', The world bank economic review 15(3), 341--365.

Eichengreen, B. J. (2007), 'The Cautious Case for Capital Flows 1'.

Eichengreen, B. J. (2004), Capital flows and crises, MIT press.

Eichengreen, B. J. \& Gupta, P. D. E. C. O. S. (2016), 'Managing sudden stops'(7639), Technical report, The World Bank.

Engle, R. (1982), 'Autoregressive Conditional Heteroscedasticity with Estimates of the Variance of United Kingdom Inflation', Econometrica 50(4), 987-1007.

Engle, R. F. \& Rangel, J. G. (2008), 'The Spline-GARCH Model for Low-Frequency Volatility and Its Global Macroeconomic Causes', Review of Financial Studies 21(3), 1187-1222.

Feibelman, A. (2014), 'The IMF and Regulation of Cross-Border Capital Flows', Chi. J. Int'l L. 15, 409.

Forbes, K.; Fratzscher, M. \& Straub, R. (2015), 'Capital-flow management measures: What are they good for?', Journal of International Economics 96(S1), S76-S97. 
Forbes, K.; Reinhardt, D. \& Wieladek, T. (2016), 'The Spillovers, Interactions, and (Un)Intended Consequences of Monetary and Regulatory Policies'(22307), Technical report, National Bureau of Economic Research.

Forbes, K. J. \& Warnock, F. E. (2012), 'Capital flow waves: Surges, stops, flight, and retrenchment', Journal of International Economics 88(2), 235-251.

Fratzscher, M. (2012), 'Capital flows, push versus pull factors and the global financial crisis', Journal of International Economics 88(2), 341-356.

Gallagher, K. P. \& Tian, Y. (2014), 'Regulating capital flows in emerging markets: the IMF and the global financial crisis', Boston University-Global Economic Governance Initiative (GEGI) Working Paper, May (5).

Geweke, J. (2005), Contemporary Bayesian econometrics and statistics, Vol. 537, John Wiley \& Sons.

Ghosh, A. R.; Ostry, J. D. \& Qureshi, M. S. (2016), 'When Do Capital Inflow Surges End in Tears?', American Economic Review 106(5), 581-85.

Ghosh, A. R.; Qureshi, M. \& Sugawara, N. (2014), 'Regulating Capital Flows at Both Ends; Does it Work?'(14/188), Technical report, International Monetary Fund.

Ghosh, A. R.; Qureshi, M. S.; Kim, J. I. \& Zalduendo, J. (2014), 'Surges', Journal of International Economics 92(2), 266-285.

Goldstein, I. \& Razin, A. (2006), 'An information-based tradeoff between foreign direct investment and foreign portfolio investment', Journal of International Economics 70(1), 271-295 .

Gourinchas, P.-O. \& Rey, H. (2005), 'International Financial Adjustment'(11155), Technical report, National Bureau of Economic Research.

Gourinchas, P.-O.; Rey, H. \& Truempler, K. (2011), 'The Financial Crisis and The Geography of Wealth Transfers'(17353), Technical report, National Bureau of Economic Research.

Hau, H. \& Rey, H. (2002), 'Exchange Rate, Equity Prices and Capital Flows'(9398), Technical report, National Bureau of Economic Research, Inc.

IMF (2012), 'The Liberalization and Management of Capital Flows: An Institutional View, International Monetary Fund.

IMF (2016), 'World Economic Outlook: Too Slow for Too Long', International Monetary Fund, Washington DC.

IMF (2016), 'Capital Flows - Review of Experience with the Institutional View', Board Paper, International Monetary Fund, Washington DC. 
Jeanne, O.; Subramanian, A. \& Williamson, J. (2012), Who needs to open the capital account, Peterson Institute.

Jinjarak, Y.; Wongswan, J. \& Zheng, H. (2011), 'International fund investment and local market returns', Journal of Banking \& Finance 35(3), 572--587.

Koepke, R. (2015), 'What Drives Capital Flows to Emerging Markets? A Survey of the Empirical Literature'(62770), Technical report, University Library of Munich, Germany.

Kose, M. A.; Otrok, C. \& Whiteman, C. H. (2003), 'International Business Cycles: World, Region, and Country-Specific Factors', American Economic Review 93(4), 1216-1239.

Kose, M. A.; Prasad, E. S. \& Terrones, M. E. (2009), 'Does financial globalization promote risk sharing? ', Journal of Development Economics 89(2), 258 - 270.

Lütkepohl, H. \& Krätzig, M. (2004), Applied Time Series Econometrics, Cambridge University Press.

Lagoarde-Segot, T. (2009), 'Financial reforms and time-varying microstructures in emerging equity markets', Journal of Banking \& Finance 33(10), 1755--1769.

Lane, P. \& Milesi-Ferretti, G. M. (2010), 'Cross-Border Investment in Small International Financial Centers'(iiisdp316), Technical report, IIIS.

Lane, P. R. \& Milesi-Ferretti, G. M. (2007), 'The external wealth of nations mark II: Revised and extended estimates of foreign assets and liabilities, 1970-2004', Journal of International Economics 73(2), 223-250.

Martin, P. \& Rey, H. (2006), 'Globalization and emerging markets: With or without crash?', The American Economic Review 96(5), 1631--1651.

Milesi-Ferretti, G. M. \& Lane, P. (2011), 'External Adjustment and the Global Crisis'(iiisdp369), Technical report, IIIS.

Milesi-Ferretti, G.-M. \& Tille, C. (2011), 'The Great Retrenchment: International Capital Flows During the Global Financial Crisis'(382011), Technical report, Hong Kong Institute for Monetary Research.

Mundell, R. A. (1963), 'Capital Mobility and Stabilization Policy under Fixed and Flexible Exchange Rates', The Canadian Journal of Economics and Political Science / Revue canadienne d'Economique et de Science politique 29(4), 475-485.

Neumann, R. M.; Penl, R. \& Tanku, A. (2009), 'Volatility of capital flows and financial liberalization: Do specific flows respond differently?', International review of economics \& finance 18(3), 488--501. 
Nier, E. W.; Saadi-Sedik, T. \& Mondino, T. (2014), 'Gross Private Capital Flows to Emerging Markets: Can the Global Financial Cycle Be Tamed?', IMF Working Paper.

Obstfeld, M. (2011), 'Financial Flows, Financial Crises, and Global Imbalances'(8611), Technical report, C.E.P.R. Discussion Papers.

Obstfeld, M. (2012), 'Does the Current Account Still Matter?', American Economic Review 102(3), 1-23.

Obstfeld, M. (2015), Trilemmas and Tradeoffs: Living with Financial Globalization, in Claudio Raddatz; Diego Saravia \& Jaume Ventura, ed., 'Global Liquidity, Spillovers to Emerging Markets and Policy Responses', Central Bank of Chile, pp. 013-078.

Ostry, J.; Ghosh, A.; Habermeier, K. F.; Laeven, L.; Chamon, M.; Qureshi, M. \& Kokenyne, A. (2011), 'Managing Capital Inflows; What Tools to Use?'(11/06), Technical report, International Monetary Fund.

Pasricha, G. K. (2012), 'Recent trends in measures to manage capital flows in emerging economies ', The North American Journal of Economics and Finance 23(3), 286 - 309.

Passari, E. \& Rey, H. (2015), 'Financial Flows and the International Monetary System'(21172), Technical report, National Bureau of Economic Research.

Poghosyan, T. and H. Hesse (2009) "Oil Prices and Bank Profitability: Evidence from Major Oil Exporting Countries in the Middle East and North Africa." IMF Working Paper 09/220. Washington, D.C.

Ramey, G. \& Ramey, V. A. (1995), 'Cross-Country Evidence on the Link between Volatility and Growth', American Economic Review 85(5), 1138-51.

Reinhart, C.; Calvo, G. \& Leiderman, L. (1993), 'Capital Inflows and Real Exchange Rate Appreciation in Latin America: The Role of External Factors'(7125), Technical report, University Library of Munich, Germany.

Reinhart, C.; Calvo, G. \& Leiderman, L. (1996), 'Inflows of capital to developing countries in the 1990s'(13707), Technical report, University Library of Munich, Germany.

Reinhart, C. M. \& Reinhart, V. R. (2008), 'Capital Flow Bonanzas: An Encompassing View of the Past and Present'(14321), Technical report, National Bureau of Economic Research.

Rey, H. (2013), 'Dilemma not trilemma: the global cycle and monetary policy independence', Proceedings - Economic Policy Symposium - Jackson Hole, 1-2.

Rey, H. (2016), 'International channels of transmission of monetary policy and the Mundellian trilemma', IMF Economic Review 64(1), 6--35. 
Rigobon, R. \& Broner, F. A. (2005), 'Why are Capital Flows So Much More Volatile in Emerging Than in Developed Countries?', Documentos de Trabajo (Banco Central de Chile) (328), 1.

Siemer, M.; Verdelhan, A. \& Gourio, F. (2015), 'Uncertainty and International Capital Flows'(880), Technical report, Society for Economic Dynamics.

Stock, J. H. \& Watson, M. W. (2001), 'Vector Autoregressions', Journal of Economic Perspectives 15(4), 101-115.

Svirydzenka, K. (2016), 'Introducing a New Broad-based Index of Financial Development'(16/5), Technical report, International Monetary Fund.

Tesar, L. L. \& Werner, I. M. (1995), 'US equity investment in emerging stock markets', The World Bank Economic Review 9(1), 109--129.

Umutlu, M.; Akdeniz, L. \& Altay-Salih, A. (2010), 'The degree of financial liberalization and aggregated stock-return volatility in emerging markets', Journal of banking \& finance 34(3), 509--521.

Verdelhan, A. \& Dou, W. W. (2015), 'The Volatility of International Capital Flows and Foreign Assets'.

World Bank (2016), 'Global Economic Prospects, January 2016: Spillovers Amid Weak Growth', World Bank Group, Washington, DC. 
VIII. APPENDIX

\section{A. Countries}

\begin{tabular}{|c|c|c|}
\hline \multicolumn{3}{|c|}{ Advanced Economies } \\
\hline Australia & \multicolumn{2}{|l|}{ Iceland } \\
\hline Belgium & \multicolumn{2}{|l|}{ Israel } \\
\hline Canada & \multicolumn{2}{|l|}{ Italy } \\
\hline Switzerland & \multicolumn{2}{|l|}{ Japan } \\
\hline Cyprus & \multicolumn{2}{|l|}{ Korea } \\
\hline Czech Republic & \multicolumn{2}{|l|}{ Luxembourg } \\
\hline Germany & \multicolumn{2}{|l|}{ Norway } \\
\hline Spain & \multicolumn{2}{|l|}{ New Zealand } \\
\hline Estonia & \multicolumn{2}{|l|}{ Portugal } \\
\hline France & \multicolumn{2}{|l|}{ Singapore } \\
\hline United Kingdom & \multicolumn{2}{|l|}{ Slovakia } \\
\hline Greece & \multicolumn{2}{|l|}{ Slovenia } \\
\hline Hong Kong SAR & \multicolumn{2}{|l|}{ Taiwan POC } \\
\hline Ireland & \multicolumn{2}{|l|}{ United States } \\
\hline \multicolumn{3}{|c|}{ Emerging Market and Developing Economies } \\
\hline Albania & India & Russia \\
\hline Bulgaria & Jordan & Saudi Arabia \\
\hline Belarus & Kazakhstan & El Salvador \\
\hline Brazil & Sri Lanka & Serbia \\
\hline Chile & Lithuania & Thailand \\
\hline China & Latvia & Turkey \\
\hline Colombia & Mexico & Ukraine \\
\hline Costa Rica & Makedonia & Uruguay \\
\hline Ecuador & Malaysia & South Africa \\
\hline Egypt & Peru & \\
\hline Guatemala & Philippines & \\
\hline Croatia & Poland & \\
\hline Hungary & Paraguay & \\
\hline Indonesia & Romania & \\
\hline
\end{tabular}




\section{B. Variables}

\begin{tabular}{|c|c|c|c|c|}
\hline Variable & Frequency & Time coverage & Countries & Source \\
\hline \multicolumn{5}{|l|}{ Capital flows } \\
\hline Total flows & Quarterly & 1970Q1:2016Q1 & 65 & IMF-IFS \\
\hline FDI & Quarterly & 1970Q1:2016Q1 & 65 & IMF-IFS \\
\hline Portfolio & Quarterly & 1970Q1:2016Q1 & 65 & IMF-IFS \\
\hline Portfolio Debt & Quarterly & 1970Q1:2016Q1 & 65 & IMF-IFS \\
\hline Portfolio Equity & Quarterly & 1970Q1:2016Q1 & 65 & IMF-IFS \\
\hline Other & Quarterly & 1970Q1:2016Q1 & 65 & IMF-IFS \\
\hline \multicolumn{5}{|l|}{ Macroeconomic Factors } \\
\hline Real GDP & Quarterly & 1970Q1:2016Q1 & 37 & IMF-WEO \\
\hline Nominal GDP & Quarterly & 1970Q1:2016Q1 & 37 & IMF-IFS \\
\hline CPI & Quarterly & 1970Q1:2016Q1 & 37 & IMF-IFS \\
\hline Policy rate & Quarterly & 1970Q1:2016Q1 & 37 & IMF-IFS \\
\hline Exchange rate vs USD & Quarterly & 1970Q1:2016Q1 & 37 & IMF-IFS \\
\hline \multicolumn{5}{|l|}{ Structural Factors } \\
\hline Public debt & Quarterly & 1970Q1:2016Q1 & 37 & IMF-IFS \\
\hline International Reserves & Quarterly & 1970Q1:2016Q1 & 37 & IMF-IFS \\
\hline Trade openness & Quarterly & 1970Q1:2016Q1 & 37 & IMF-DOTM \\
\hline Financial Development Index & Annual & $1979-2015$ & 37 & Svirydzenka(2016) \\
\hline Capital Account Openness & Annual & $1996-2014$ & 37 & Chinn and Ito(2008) \\
\hline Institutional Stability & Quarterly & 1996Q4:2014Q4 & 37 & WB-WGI \\
\hline \multicolumn{5}{|l|}{ Global Factors } \\
\hline US Wu-Xia Shadow Rate & Quarterly & 1982Q1:2016Q2 & & Haver Analytics \\
\hline S\&P 500 volatility & Quarterly & 1970Q1:2016Q2 & & Haver Analytics \\
\hline US real GDP & Quarterly & 1970Q1:2016Q1 & & IMF-WEO \\
\hline US CPI & Quarterly & 1970Q1:2016Q1 & & IMF-IFS \\
\hline US Corporate Bond Spread & Quarterly & 1991Q3:2016Q1 & & FRED \\
\hline US Government Yield Spread & Quarterly & 1970Q1:2016Q1 & & IMF-IFS \\
\hline Global Liquidity & Quarterly & 1970Q1:2016Q1 & & NCBs \\
\hline Oil price & Quarterly & 1970Q1:2016Q1 & & IMF-IFS \\
\hline
\end{tabular}

Table 2: List of variables with time coverage and sources. Notes: Trade Openness: sum of imports plus exports over GDP; Capital Account Openness = Chinn-Ito index; Institutional Stability = Rule of Law index; S\&P 500 volatility = realized returns volatility for the S\&P 500 Index; US Gov't Yield Spread $=$ difference between the 10-year and the 3-year US government bond yields; Global Liquidity = sum of M2 aggregates across the G7 economies; Oil price = Brent spot price (USD per barrel). Sources: IMF-IFS = International Financial Statistics; IMF-DOTM = Direction of Trade Monthly; IMF-WEO = World Economic Outlook; WB-WGI $=$ World Bank Worldwide Governance Indicators; FRED = Federal Reserve Economic Database; NCBs = National Central Banks. 


\section{Geweke's Separated Partial Means Test}

The Geweke's separated partial means test is used to check the convergence of a parameter estimate over time. Define $M$ as the sample length and $p$ as a fixed positive integer equal to the number of means which you want to split the sample into.

Given a sequence of a $(k \times 1)$ vector of parameters of interest, $\left\{\boldsymbol{\theta}_{m=1}^{M}\right.$, and for each sample length $M$ such that $M_{p}=M / 2 p$ is an integer, the $p$ separated means are defined as:

$$
\bar{h}_{j, p}^{(M)}=M_{p}^{-1} \sum_{m=1}^{M_{p}} \theta_{i}^{(m+M(2 j-1) / 2 p)}, j=1, \ldots, p, i=1, \ldots, k
$$

Let $\hat{\tau}_{j, p}^{2(M)}$ be the estimate for the variance ${ }^{33}, \tau^{2}$, of $\bar{h}_{j, p}^{(M)}$, which is computed as follows:

$$
\widehat{\tau}_{j, p}^{2(M)}=\hat{S}(0)=\hat{c}_{0}^{(M)}+2 \sum_{s=1}^{L-1}[(L-s) / L] \hat{c}_{s}^{(M)},
$$

where $\hat{c}_{j}^{(M)}=M^{-1} \sum_{m=j+1}^{M}\left[\theta_{i}^{(m)}-\bar{\theta}_{i}^{(M)}\right]\left[\theta_{i}^{(m-j)}-\bar{\theta}_{i}^{(M)}\right], j=0, \pm 1, \pm 2, \ldots$ is the sample autocovariance function and $L(M)$ is an integer-valued function such that $\lim _{M \rightarrow \infty} L(M)=\infty$ and $\lim _{M \rightarrow \infty} L(M)^{2} / M=0$.

In addition, define the $(p-1) \times 1$ vector $\overline{\boldsymbol{h}}_{p}^{(M)}$ with $j$ th element $\bar{h}_{j+1, p}^{(M)}-\bar{h}_{j, p}^{(M)}$, and the $(p-1) \times(p$ 1) tridiagonal matrix $\widehat{\boldsymbol{V}}_{p}^{(M)}$, in which $\hat{v}_{j j}^{(M)}=M_{p}^{-1}\left(\hat{\tau}_{j, p}^{2(M)}+\widehat{\tau}_{j+1, p}^{2(M)}\right)$ and $\hat{v}_{j j-1}^{(M)}=\hat{v}_{j-1 j}^{(M)}=$ $-M_{p}^{-1} \widehat{\tau}_{j, p}^{2(M)}$. It follows that:

$$
G=\overline{\boldsymbol{h}}_{p}^{(M)^{\prime}}\left[\widehat{\boldsymbol{V}}_{p}^{(M)}\right]^{-1} \overline{\boldsymbol{h}}_{p}^{(M)} \stackrel{d}{\rightarrow} \chi^{2}(p-1)
$$

where $G$ is the statistic used to test whether the separated means are equal (null hypothesis) or not (alternative) $)^{34}$.

In our case, we want to check whether the mean value of volatility of capital flows in the precrisis period $(2000 \mathrm{Q} 1: 2007 \mathrm{Q} 2)$ is the same as the mean value in the post-GFC period (2009Q3:2016Q1). In order to do so, we perform the separated partial means test over our volatility estimates $(\boldsymbol{\theta})$, by setting $p=2$ and $L(M)=0.02 * M^{35}$.

\footnotetext{
${ }^{33}$ i.e. the numerical standard error (NSE).

${ }^{34}$ Refer to Geweke (2005) for proof.

${ }^{35}$ In other words, we taper the autocovariance function at $2 \%$.
} 


\section{Volatility Adjusted for Levels}

\section{Net Flows}

Total

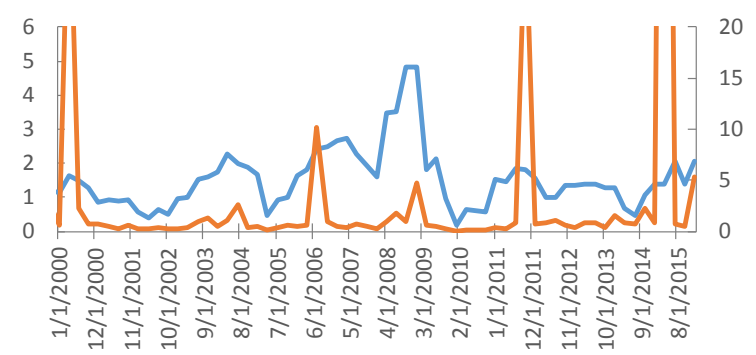

Portfolio total

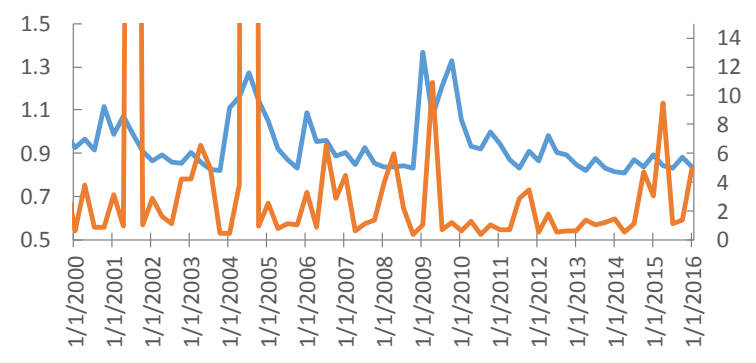

Portfolio Equity

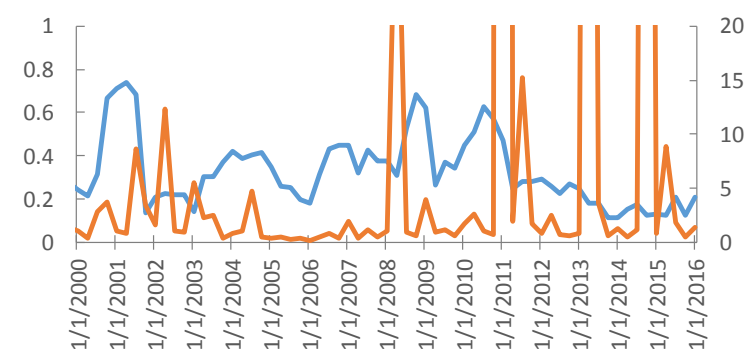

FDI

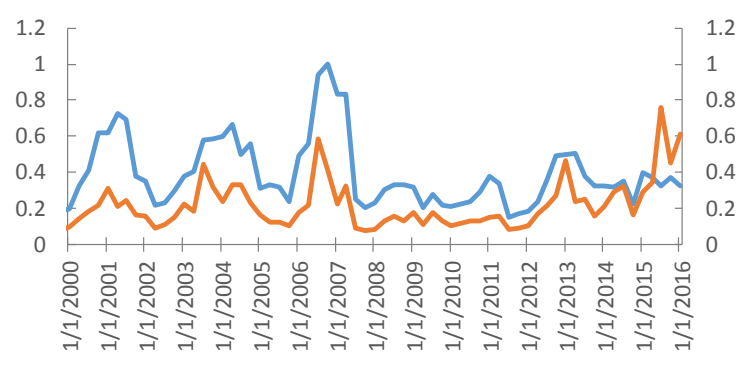

Portfolio Debt

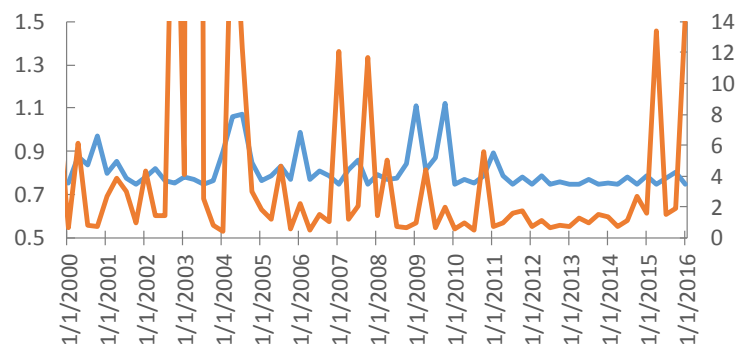

Other

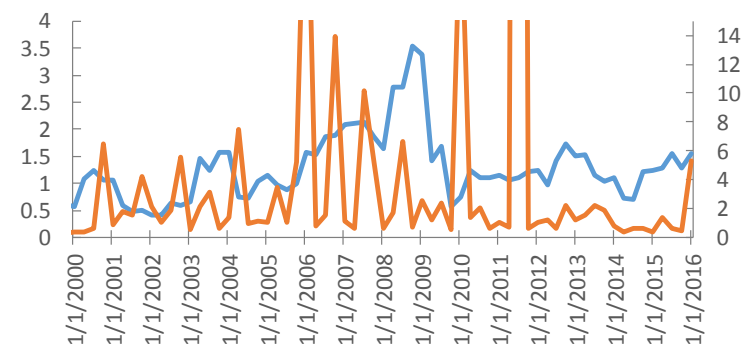

—Volatility —Adjusted Volatility (RHS)

Figure D1: volatility and adjusted volatility (coefficient of variation) for net capital flows in EMDEs by instrument. Notes: measures are expressed as \% share of group GDP. Source: IMF, International Financial Statistics, authors' computations. 


\section{Gross Inflows}

Total

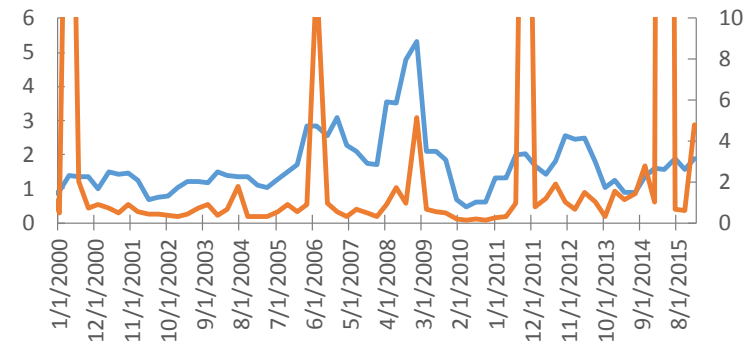

Portfolio total

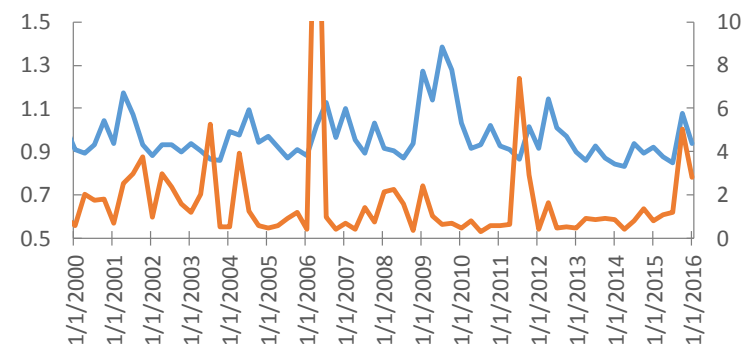

Portfolio Equity

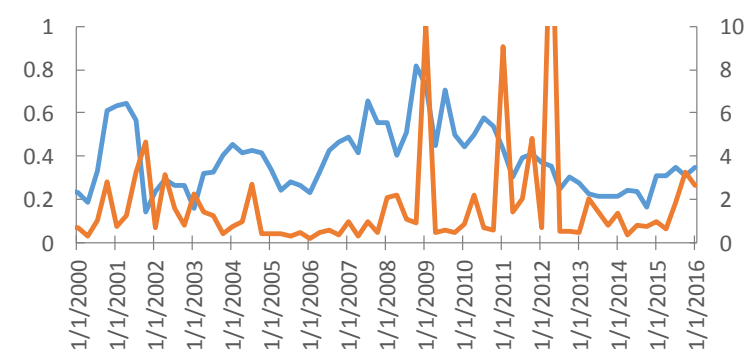

FDI

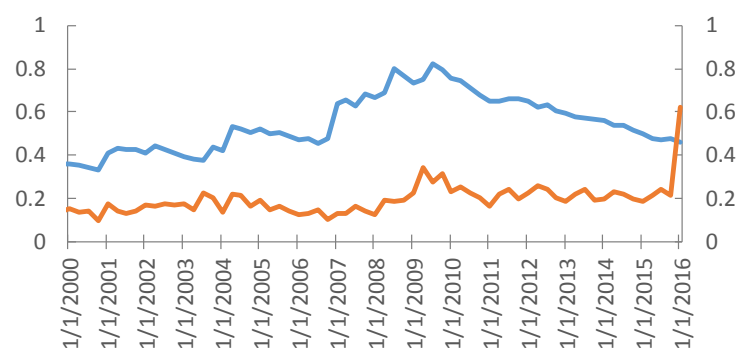

Portfolio Debt

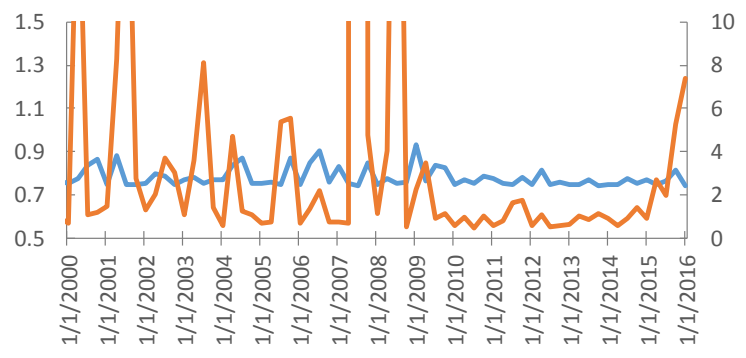

Other

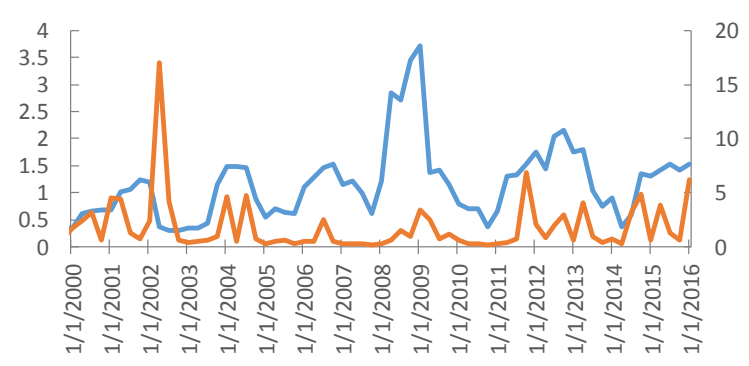

—Volatility —Adjusted Volatility (RHS)

Figure D2: volatility and adjusted volatility (coefficient of variation) for gross capital inflows in EMDEs by instrument. Notes: measures are expressed as \% share of group GDP. Source: IMF, International Financial Statistics, authors' computations. 


\section{E. Volatility of Capital Flows excluding China}

a)

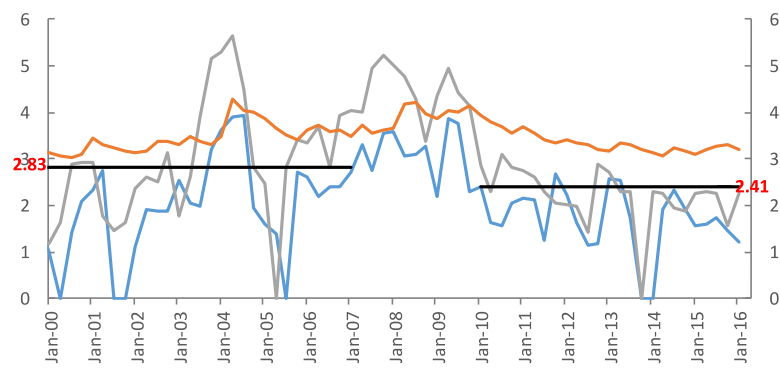

c)

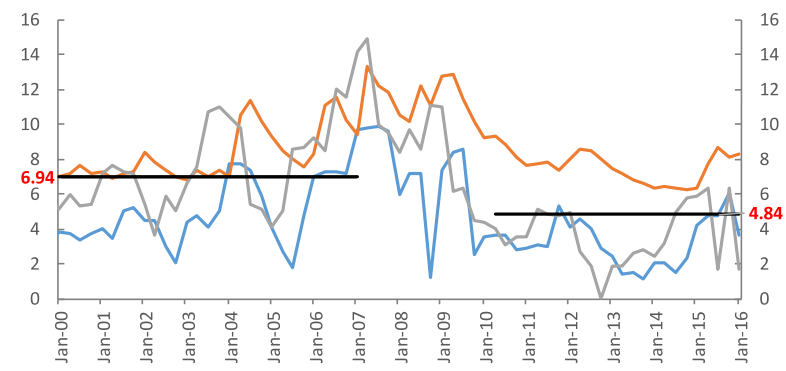

b)

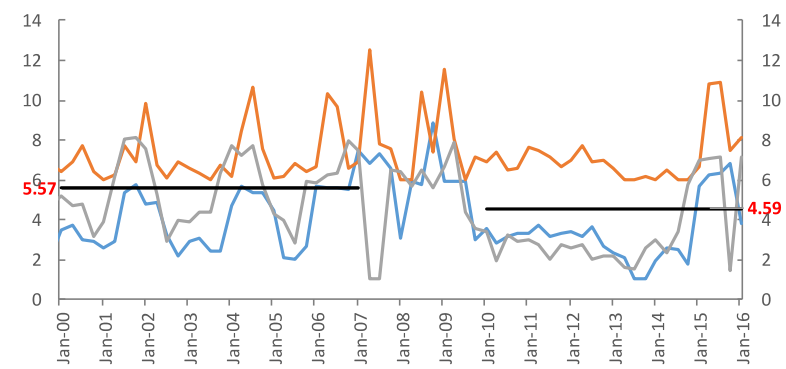

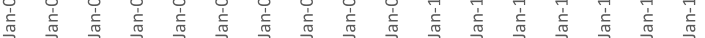

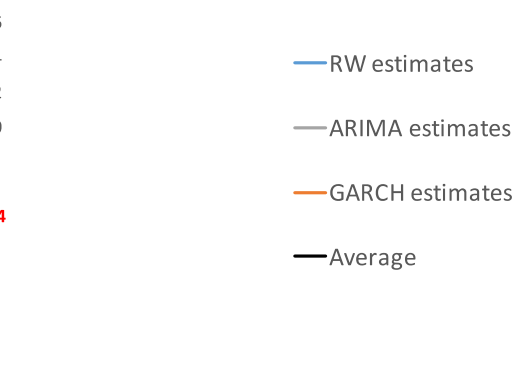

Figure E1: Volatility of capital flows for the World aggregate, excluding China. Notes: a) Net Inflows; b) Gross Inflows; c) Gross Outflows. Measures are expressed as \% of total GDP. Source: IMF, International Financial Statistics, authors' computations.

a)

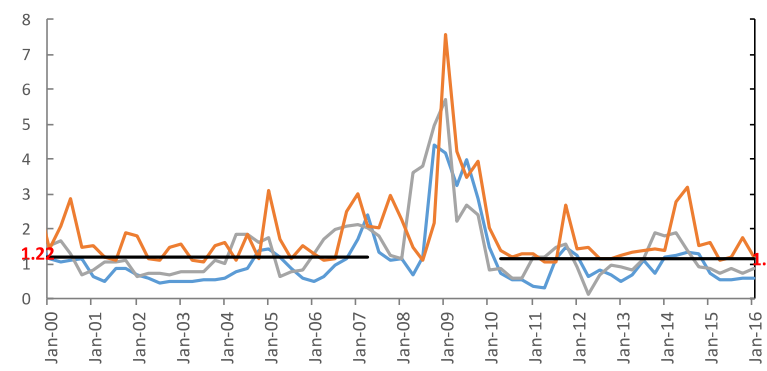

c)

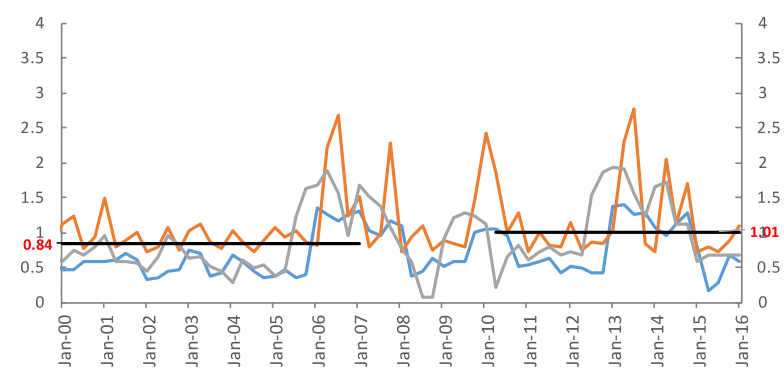

b)

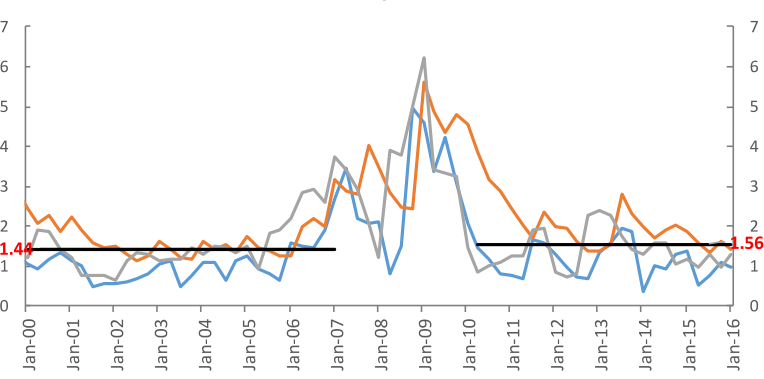

—RW estimates

—ARIMA estimates

— GARCH estimates

-Average

Figure E2: Volatility of capital flows in EMDEs, excluding China. Notes: a) Net Inflows; b) Gross Inflows; c) Gross Outflows. Measures are expressed as \% of group GDP. Source: IMF, International Financial Statistics, authors' computations. 
FDI

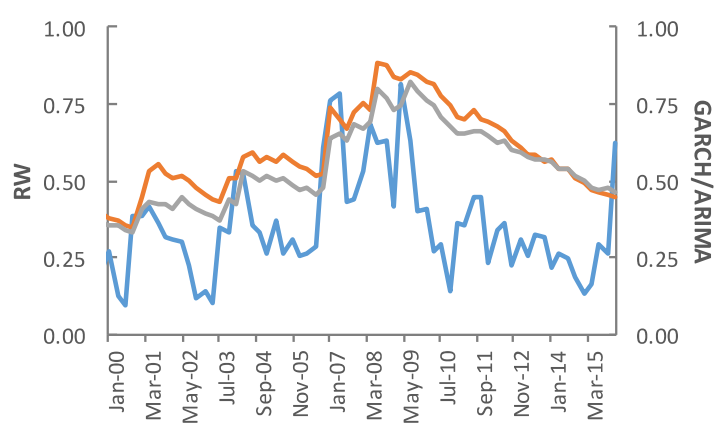

Portfolio Debt

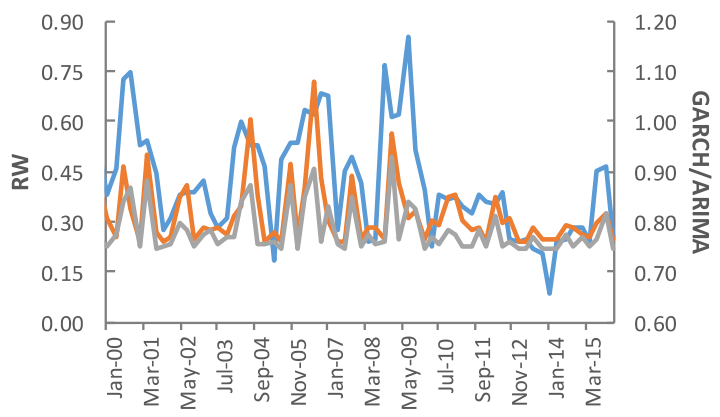

Other

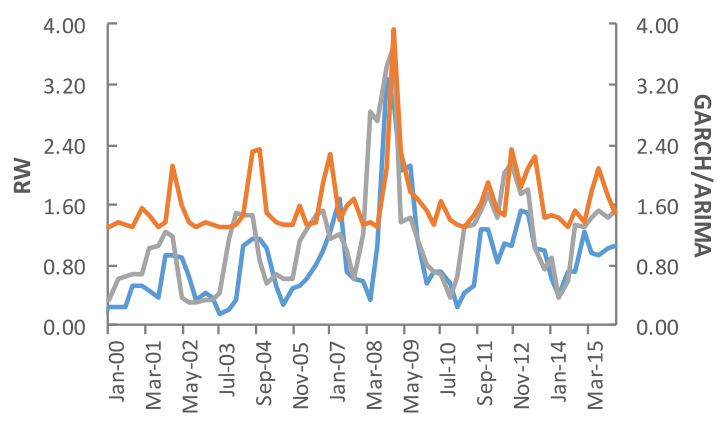

Portfolio Total

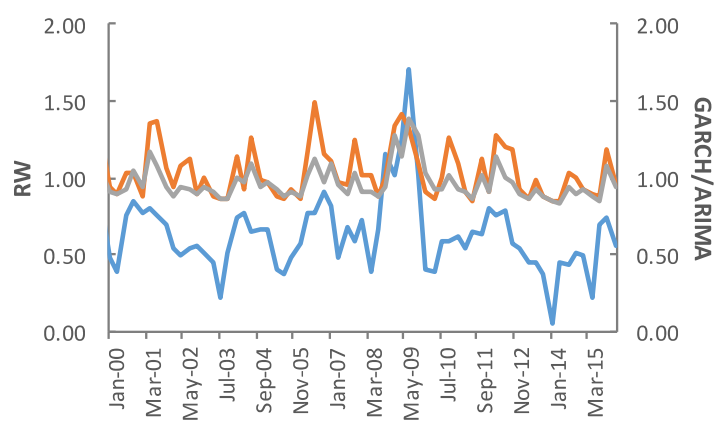

Portfolio Equity

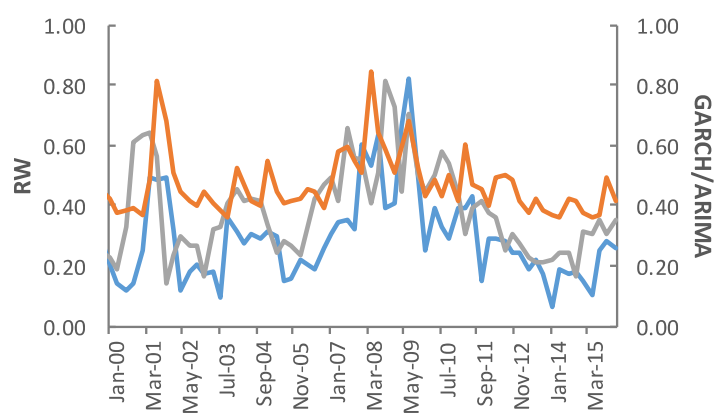

Figure E3: Volatility of gross capital inflows for EMDEs excluding China by components. Note: volatility is expressed as \% of group GDP. Source: IMF, International Financial Statistics, authors' computations. 


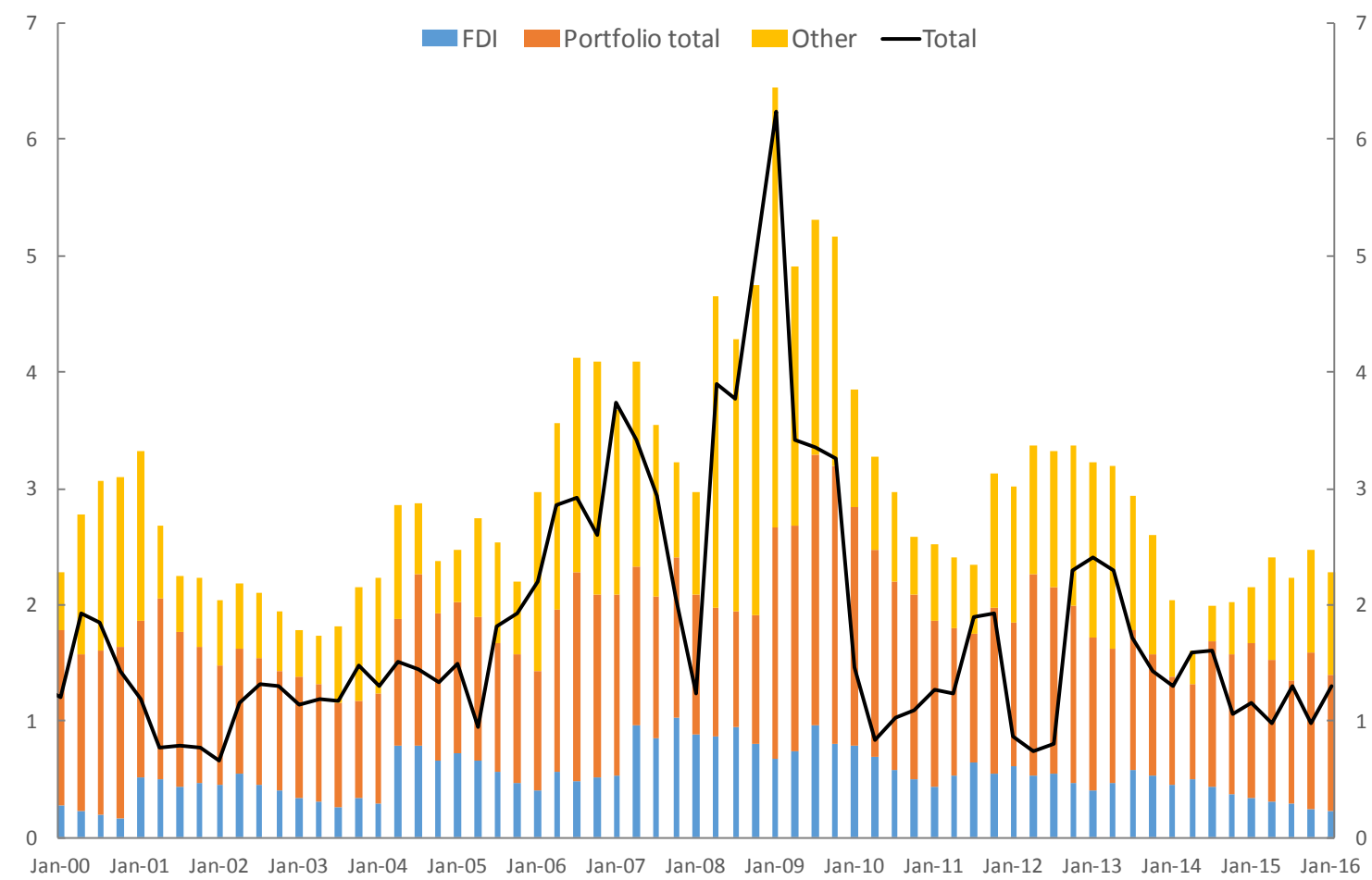

Figure E4: ARIMA volatility estimates of aggregate gross capital inflows and their components in EMDEs, excluding China. Notes: Measures are expressed as \% of group GDP. Source: IMF, International Financial Statistics, authors' computations. 